In Cooperation With the Miami Conservancy District

\title{
Relation Between Solid-Phase and Dissolved Arsenic in the Ground-Water System Underlying Northern Preble County, Ohio
}

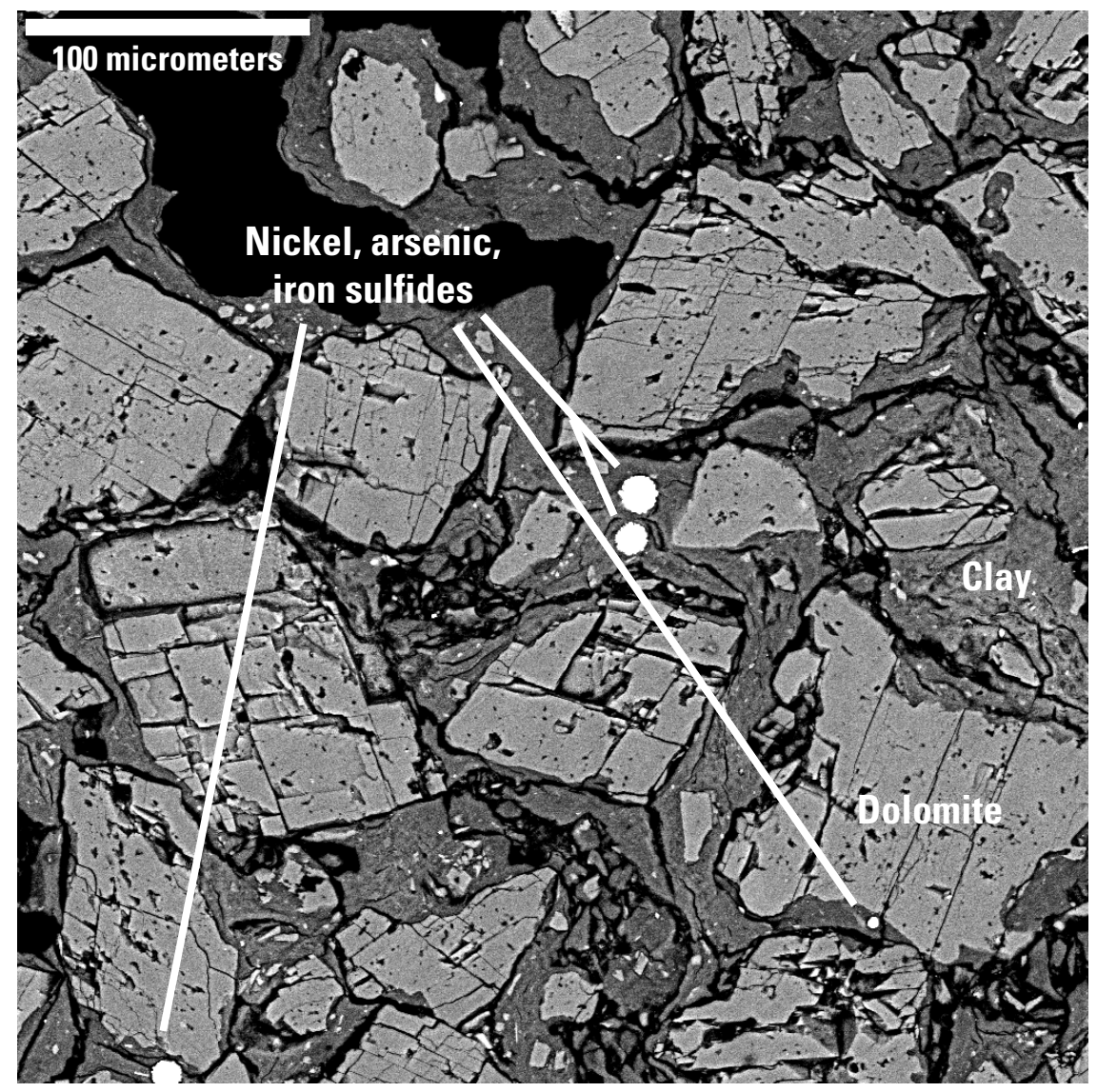

Scientific Investigations Report 2008-5205 
Cover image. Micrograph of a sample from the unconsolidated bedrock zone at site 1, Preble County, Ohio, showing etched dolomite rhombs in a clay matrix. (Image produced by Sharon Diehl, U.S. Geological Survey.) 


\section{Relation Between Solid-Phase and Dissolved Arsenic in the Ground-Water System Underlying Northern Preble County, Ohio}

By Mary Ann Thomas, Sharon F. Diehl, Bruce A. Pletsch, Thomas L. Schumann, Richard R. Pavey, and E. Mac Swinford

In cooperation with the Miami Conservancy District

Scientific Investigations Report 2008-5205 


\section{U.S. Department of the Interior DIRK KEMPTHORNE, Secretary}

\section{U.S. Geological Survey \\ Mark D. Myers, Director}

\section{U.S. Geological Survey, Reston, Virginia: 2008}

For product and ordering information:

World Wide Web: http://www.usgs.gov/pubprod

Telephone: 1-888-ASK-USGS

For more information on the USGS — the Federal source for science about the Earth, its natural and living resources, natural hazards, and the environment:

World Wide Web: http://www.usgs.gov

Telephone: 1-888-ASK-USGS

Any use of trade, product, or firm names is for descriptive purposes only and does not imply endorsement by the U.S. Government.

Although this report is in the public domain, permission must be secured from the individual copyright owners to reproduce any copyrighted materials contained within this report.

Suggested citation:

Thomas, M.A., Diehl, S.F., Pletsch, B.A., Schumann, T.L., Pavey, R.R., and Swinford, E.M., 2008, Relation between solid-phase and dissolved arsenic in the ground-water system underlying northern Preble County, Ohio: U.S.

Geological Survey Scientific Investigations Report 2008-5205, 56 p. 


\section{Contents}

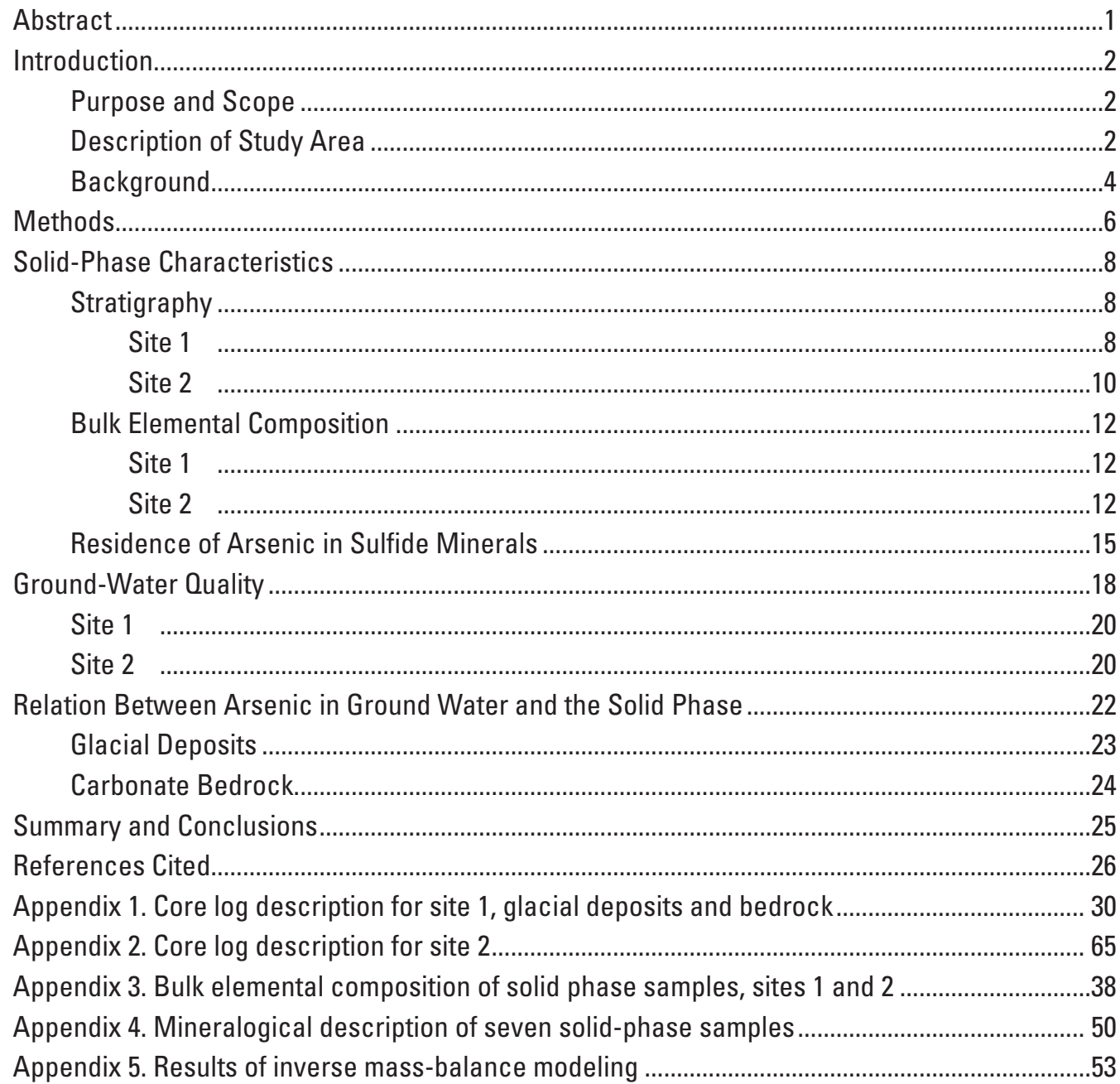

\section{Figures}

1. Map showing location of study sites in northern Preble County, Ohio .................................

2. Simplified stratigraphic column, site 1 in northern Preble County, Ohio ..............................9

3. Simplified stratigraphic column, site 2 in northern Preble County, Ohio .............................11

4. Graphs showing solid-phase concentrations of arsenic, iron, sufur, and organic carbon at sites 1 and 2 in nothern Preble County, Ohio .................................................13

5-9. Micrographs of selected samples from-

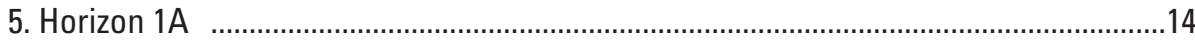

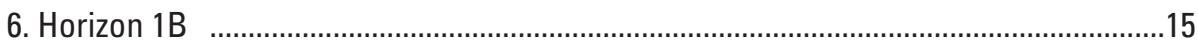

7. Unconsolidated bedrock zone at site 1 ...................................................................16

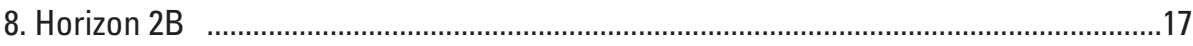

9. Horizon 2C 
10. Graphs showing concentrations of dissolved arsenic, iron, sulfate, sulfide and organic carbon at sites 1 and 2 in nothern Preble County, Ohio.

11. Graph showing relation between arsenic concentrations in the solid phase and ground water

\section{Tables}

1. Arsenic concentrations for selected geologic materials.

2. Simplified conceptual model of the interaction between arsenic-bearing minerals and ground water under different redox conditions

3. Characteristics of sampled wells .6

4. Threshold concentrations of water-quality constituents for assessing redox processes

5. Arsenic concentrations in solid-phase samples, northern Preble County, Ohio 12

6. Selected water-quality constituents and properties from six horizons

\section{Conversion Factors}

\begin{tabular}{lcl}
\hline \multicolumn{1}{c}{ Multiply } & By & \multicolumn{1}{c}{ To obtain } \\
\hline inch (in.) & 25.4 & millimeter $(\mathrm{mm})$ \\
foot (ft) & 0.3048 & meter $(\mathrm{m})$ \\
mile (mi) & 1.609 & kilometer $(\mathrm{km})$ \\
\hline
\end{tabular}

Vertical coordinate information is referenced to the National Geodetic Vertical Datum of 1929 (NGVD 29).

Horizontal coordinate information is referenced to the North American Datum of 1983 (NAD 83).

Altitude, as used in this report, refers to distance above the vertical datum.

Specific conductance is given in microsiemens per centimeter at 25 degrees Celsius $(\mu \mathrm{S} / \mathrm{cm}$ at $25^{\circ} \mathrm{C}$ ).

Concentrations of chemical constituents in water are given either in milligrams per liter (mg/L) or micrograms per liter $(\mu \mathrm{g} / \mathrm{L})$

Concentrations of chemical constituents in solid-phase samples are given in milligrams per kilogram $(\mathrm{mg} / \mathrm{kg})$, which is equivalent to parts per million (ppm). 


\title{
Relation Between Solid Phase and Dissolved Arsenic in the Ground-Water System Underlying Northern Preble County, Ohio
}

\author{
By Mary Ann Thomas' ${ }^{1}$ Sharon F. Diehl'², Bruce A. Pletsch ${ }^{3}$, Thomas L. Schumann ${ }^{4}$, Richard R. Pavey ${ }^{5}$, \\ and E. Mac Swinford ${ }^{5}$
}

\section{Abstract}

The U.S. Geological Survey (USGS), in cooperation with the Miami Conservancy District, collected and analyzed samples of the aquifer materials and ground water from multiple depths at two sites in northern Preble County, Ohio. The aquifer materials included glacial deposits and Silurian carbonate bedrock. In the study area, elevated arsenic concentrations have been detected in ground water from both types of aquifers.

The aquifer materials were described in terms of the stratigraphy and the bulk elemental composition of 70 samples. In addition, six water-producing horizons were selected for more detailed study; ground-water quality was analyzed, microanalytical techniques were used to examine thin sections of the aquifer materials, and simplified geochemical modeling was done to identify plausible reactions between the ground water and aquifer materials.

At both study sites, the highest solid-phase arsenic concentrations were from a roughly similar stratigraphic position - a transition zone that extends from just above the Wisconsinan/Illinoian contact to just below the Pleistocene/ Silurian contact.

For carbonate bedrock, the solid-phase arsenic concentrations were generally low ( $<1$ to $4 \mathrm{mg} / \mathrm{kg}$ (milligrams per kilogram)). The one notable exception was a thin horizon about 10 feet below the top of bedrock, which had an arsenic concentration of $42 \mathrm{mg} / \mathrm{kg}$. This horizon showed some textural and compositional evidence of alteration by geothermal fluids.
Additional study might be warranted to investigate whether arsenic concentrations in ground water from carbonate bedrock could be decreased by excluding discrete horizons from the open intervals of wells.

For glacial deposits, solid-phase arsenic concentrations were slightly higher in fine-grained deposits (2 to 20 $\mathrm{mg} / \mathrm{kg}$ ) than in coarse-grained deposits (2 to $9 \mathrm{mg} / \mathrm{kg}$ ). In ground water, arsenic concentrations ranged from $<1$ to 51 $\mu \mathrm{g} / \mathrm{L}$ (micrograms per liter); samples from two horizons had concentrations greater than the U.S. Environmental Protection Agency Maximum Contaminant Level (MCL) of $10 \mu \mathrm{g} / \mathrm{L}$. Dissolved arsenic concentrations appear to be more closely related to redox conditions of the ground water than to the arsenic content of the aquifer materials. Geochemical modeling and thin-section analysis were generally consistent with the idea that arsenic was released to water from iron oxides under iron-reducing conditions. In addition, there was some evidence in support of the idea that arsenic can be removed from ground water by precipitation of sulfide minerals, which occurs under sulfate-reducing conditions. At one site, the dissolved arsenic concentrations in two water-bearing horizons increased from $<1$ to $51 \mu \mathrm{g} / \mathrm{L}$ over a depth of 15 feet. The large increase might be due to a shift from sulfate-reducing to methanogenic conditions; in the absence of sulfate reduction, arsenic is not sequestered in sulfide minerals and may accumulate in the ground water.

\footnotetext{
${ }^{1}$ USGS Ohio Water Science Center, Columbus, Ohio.

${ }^{2}$ USGS Geologic Discipline, Lakewood, Colo.

${ }^{3}$ Miami Conservancy District, Dayton, Ohio.

${ }^{4}$ Formerly with the USGS Ohio Water Science Center, Columbus, Ohio.

${ }^{5}$ Ohio Department of Natural Resources, Division of Geological Survey, Columbus, Ohio.
} 


\section{Introduction}

Drinking water is the primary source of human exposure to arsenic. Long-term exposure to arsenic in drinking water has been linked to cancers of the bladder, skin, lungs and prostate; diabetes; cardiovascular disease; neurological dysfunction; and eye disease (National Research Council, 1999, 2001; Chen and others, 2007; Benbrahim-Tallaa and others, 2007; Lin and others, 2008). Arsenic is a potent endocrine disruptor, which might be why it influences multiple diverse disease processes (Davey and others, 2007).

The U.S. Environmental Protection (USEPA) Maximum Contaminant Level (MCL) for arsenic is 10 micrograms per liter ( $\mu \mathrm{g} / \mathrm{L})$ (U.S. Environmental Protection Agency, 2006). The MCL is applicable to public water systems but not to domestic wells. Domestic wells are not routinely tested for arsenic in most parts of the country, so homeowners may not know whether their well water has arsenic concentrations greater than the MCL. Moreover, arsenic concentrations in ground water have considerable spatial variability and are difficult to predict on a well-by-well basis. However, the risk of high arsenic concentrations is greater in some areas than in others (Smedley and Kinniburgh, 2002). If the most susceptible aquifers (or parts of aquifers) could be identified, efforts related to monitoring, education, or mitigation could be targeted to areas of greatest need.

In ground water of southwestern Ohio, arsenic concentrations 2 to 5 times the MCL have been reported by the Ohio Environmental Protection Agency (Bendula and Khoury, 1998; Ohio Environmental Protection Agency, 2000, 2002), the Miami Conservancy District (2001, 2004, 2005), and the U.S. Geological Survey (Dumouchelle, 1998; Rowe and others, 2004; Thomas and others, 2005). Elevated arsenic concentrations have been detected at a range of depths in both bedrock and glacial aquifers. It is not clear which combinations of geologic, hydrologic, or chemical factors are responsible for the spotty elevated arsenic concentrations that were detected.

In 2002, the U.S. Geological Survey (USGS), in cooperation with the Miami Conservancy District, began an investigation of arsenic in ground water of the Great Miami River Basin in southwest Ohio. The goal was to determine which parts of the aquifer system are most (and least) likely to produce water with elevated arsenic concentrations. The investigation was designed in a stepwise fashion so that results from one year's study guided the design of the next. During 2002, ground-water samples were analyzed from 29 domestic wells in selected areas of Preble, Miami, and Shelby Counties. During 2003, study areas in Preble and Shelby Counties were revisited, and ground-water samples from 28 additional domestic wells were analyzed. Data from both years were used to relate arsenic concentrations in the ground water to redox conditions, aquifer type, and geologic setting (Thomas and others, 2005). The current study, which began in 2004, focused on a smaller geographic area, but it involved more detailed analyses of both arsenic in the solid phase - that is, in the aquifer materials themselves — and dissolved arsenic. Northern Preble County was chosen for study because elevated arsenic concentrations were known to exist in glacial deposits and carbonate bedrock at sites near the recharge and discharge areas of a single watershed.

\section{Purpose and Scope}

This report summarizes the findings of the cooperative study by the USGS and the Miami Conservancy District, which also involved collaborators from the Ohio Department of Natural Resources, Division of Geological Survey. The study area includes two sites in the Price Creek watershed in northern Preble County (fig. 1). In 2004, five monitor wells were installed, and cores of the aquifer materials were retrieved. The stratigraphy was documented, and 70 solidphase samples were analyzed for bulk elemental composition. Samples from selected horizons were analyzed for groundwater chemistry and solid-phase mineralogy.

The purpose of this report is to (1) document characteristics of solid-phase aquifer materials, including stratigraphy, bulk elemental composition, and mineralogy; (2) document the ground-water chemistry of six water-producing horizons; and (3) relate arsenic concentrations in ground water to solidphase characteristics in order to increase understanding of susceptibility of the ground water in the study area to arsenic contamination.

\section{Description of Study Area}

The study area is in northern Preble County, Ohio, which is part of the Till Plains section of the Central Lowlands Physiographic Province (Fenneman and Johnson, 1946). Landsurface elevations are 1,125 to $1,200 \mathrm{ft}$, and the water table is typically 9 to $60 \mathrm{ft}$ below land surface. Land use is primarily agricultural and rural-residential. The area is near the broad axis of the Cincinnati Arch, which separates the Illinois and Appalachian Basins.

Pleistocene glacial deposits mantle the bedrock and extend to land surface. The glacial deposits are 35 to $120 \mathrm{ft}$ thick and are composed predominantly of fine-grained till. Coarse-grained sediment is present as layers or lenses within the till and as valley-fill deposits. Beneath the glacial deposits is the Silurian Lockport Dolomite, which is 30 to $200 \mathrm{ft}$ thick and typically vuggy and porous. A relatively shallow buried valley cuts across bedrock in the southeastern corner of the study area (Ohio Department of Natural Resources, Division of Geological Survey, 2004). The glacial deposits and bedrock are hydraulically connected and are considered to be part of the same regional aquifer system (Eberts and George, 

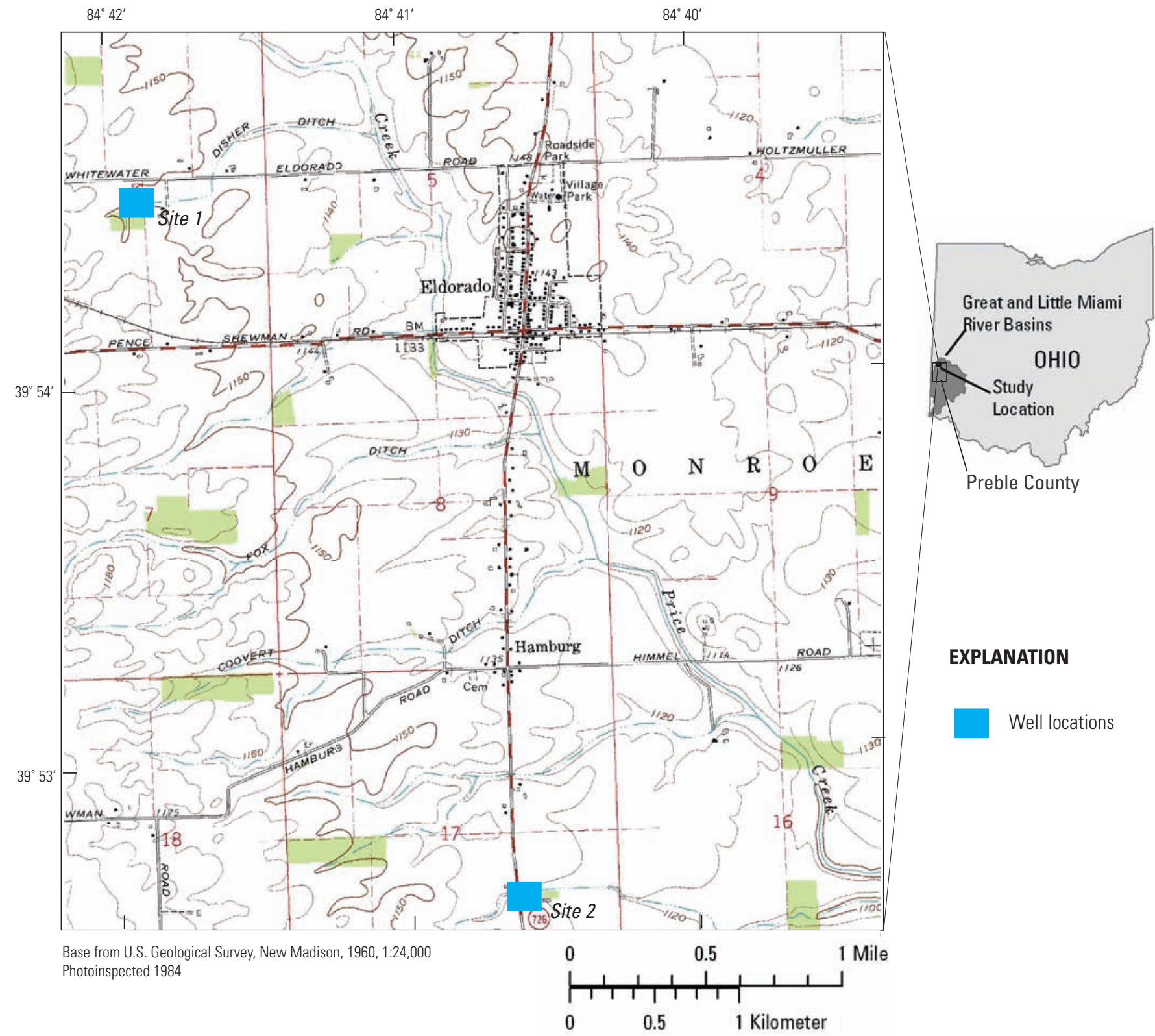

EXPLANATION

Well locations

Figure 1. Location of study sites in northern Preble County, Ohio. 
2000). Both units are used as a source of water to domestic and public-supply wells. Wells completed in bedrock typically produce water from uncased boreholes that start at the top of bedrock and extend 30 to $100 \mathrm{ft}$ into the formation. In contrast, wells completed in glacial deposits typically produce water from well screens less than $10 \mathrm{ft}$ long.

The study area consists of two sites in the Price Creek watershed (fig. 1). Site 1 is near the surface- and ground-water divides of the Great Miami River Basin and the surface-water divide of the Price Creek watershed and is therefore considered to be a recharge area in relation to regional and local ground-water flow systems. At site 1 , elevated arsenic concentrations have been detected in water samples from domestic wells that tap carbonate bedrock and coarse-grained lenses within glacial till (Thomas and others, 2005). Site 2 is $2.4 \mathrm{mi}$ southeast of site 1 , in the direction of regional ground-water flow (Eberts and George, 2000). It is near a small tributary to
Price Creek and a buried bedrock valley. At site 2, elevated arsenic concentrations have been detected in a domestic well that taps glacial valley-fill deposits (Thomas and others, 2005).

\section{Background}

For most cases of widespread arsenic contamination of ground water, the source of arsenic is naturally occurring minerals in the aquifer materials (Welch and others, 2000; Smedley and Kinniburgh, 2002). High concentrations of arsenic can occur in sulfide minerals, especially pyrite $\left(\mathrm{FeS}_{2}\right)$, and hydrous metal oxides, especially iron oxyhydroxides (FeOOH) (table 1). In sulfide minerals, arsenic can substitute for sulfur, and this substitution can increase the susceptibility of arsenic-bearing sulfides to weathering and dissolution (Savage and others, 2000). In iron oxides, arsenic can be part

Table 1. Arsenic concentrations for selected geologic materials.

[From Smedley and Kinniburgh (2002) and references therein; ppm, parts per milion (equivalent to milligrams per kilogram); --, not reported]

\begin{tabular}{lcc}
\hline \multicolumn{1}{c}{ Solid-phase material } & Average, in ppm & Range, in ppm \\
\hline Sulfide minerals: & -- & $100-77,000$ \\
Pyrite & -- & $5-17,000$ \\
Sphalerite & & \\
Oxides: & -- & Up to 2,000 \\
Fe oxide (Undifferentiated) & -- & Up to 76,000 \\
Fe(III) oxyhydroxide & 7.2 & $<1-55$ \\
Soils (various) & 13 & $2-36$ \\
Peaty and bog soils & 3 & $<1-50$ \\
Unconsolidated sediments (various) & 2.9 & $1.0-6.2$ \\
Alluvial sands (Bangladesh) & 6.5 & $2.7-14.7$ \\
Alluvial mud/clay (Bangladesh) & 9.2 & $1.9-170$ \\
Till (British Columbia) & 5.5 & $0.9-44$ \\
Lake sediments (British Columbia) & -- & $5-10$ \\
Sedimentary rocks & $<3$ & $<1-20$ \\
Limestone/dolomite & 4 & $<1-120$ \\
Sandstone & 13 & $<1-490$ \\
Shale & -- & $100-900$ \\
Bituminous shale (Germany) & 1.5 & $<1-113$ \\
Igneous rocks & $<5$ & $<1-143$ \\
Metamorphic rocks & & \\
\hline
\end{tabular}


of the mineral structure or sorbed onto the surface. In general, fine-grained deposits tend to have higher arsenic contents than coarse-grained sediment, owing to higher proportions of colloid-size iron oxides, pyrite, and organic matter (Smedley and Kinniburgh, 2002).

In the study area, sulfides and iron oxides are common components of the glacial deposits and bedrock (Stout, 1941; Gerrard, 1959; Blackman, 1970; Botomon and Stieglitz, 1978; core descriptions on file at the Columbus, Ohio, offices of the Ohio Department of Natural Resources, Division of Geological Survey). However, not much is known about the concentration, distribution, or residence of arsenic associated with the sulfide minerals and iron oxides within aquifer materials of the study area.

Arsenic concentrations in ground water are controlled largely by redox processes, $\mathrm{pH}$, and (or) competitive sorption with other anions (Smedley and Kinniburgh, 2002). In the study area, concentrations of dissolved arsenic are not strongly correlated with $\mathrm{pH}$ - probably because $\mathrm{pH}$ does not vary much, owing to buffering by carbonate minerals in aquifer materials. However, there is a significant correlation between elevated arsenic concentrations and redox conditions, and the predominant mechanism for mobilizing arsenic appears to be the release of arsenic from iron oxides under reducing conditions (Thomas and others, 2005). The same mechanism has been proposed for aquifers in other areas, including other parts of Ohio (Matisoff and others, 1982; Bendula and Khoury, 1998; Slattery and others, 2000), central Illinois (Kirk and others,
2004; Kelly and others, 2005), the midwestern United States (Welch and others, 2000; Thomas, 2003; Thomas, 2007), and Bangladesh (Smedley and Kinniburgh, 2002).

However, the relation between dissolved arsenic concentrations and redox conditions can be complex (table 2). Under oxic conditions, arsenic can be released to ground water by dissolution of pyrite and (or) removed from the ground water by precipitation of iron oxides. The opposite can occur under reducing conditions: arsenic can be released from iron oxides under iron-reducing conditions and (or) removed from the ground water by precipitation of pyrite under sulfate-reducing conditions.

Changes in redox conditions can cause arsenic to cycle back and forth between pyrite and iron oxides. Elevated arsenic concentrations in reducing ground water have been linked to a multistep process: (1) Arsenic-bearing pyrite is subjected to oxidation, and arsenic released from the pyrite is incorporated into the newly formed iron oxides. (2) A shift from oxic to iron-reducing conditions causes the arsenic associated with iron oxides to be released to the ground water. Changes in geochemical environments can be the result of fluctuations of sea level, cycles of erosion and burial, or land use (Breit and others, 2001). Land-use effects of possible consequence include the exposure of geologic materials to oxidizing conditions by mining or water extraction, or the creation of anaerobic conditions within shallow aquifers by waste disposal (Smedley and Kinniburgh, 2002; Chapelle and others, 2002).

Table 2. Simplified conceptual model of the interaction between arsenic-bearing minerals and ground water under various redox conditions.

[Gray shading indicates that a process is active]

\begin{tabular}{|c|c|c|c|c|c|c|}
\hline \multicolumn{3}{|c|}{ Redox conditions } & \multicolumn{2}{|c|}{$\begin{array}{l}\text { Processes that add arsenic to } \\
\text { the ground water- } \\
\text { dissolution of or desorption } \\
\text { from: }\end{array}$} & \multicolumn{2}{|c|}{$\begin{array}{l}\text { Processes that remove } \\
\text { arsenic from the ground } \\
\text { water-precipitation of or } \\
\text { sorption to: }\end{array}$} \\
\hline Oxidizing & $\longrightarrow$ & Reducing & $\begin{array}{c}\text { Sulfide } \\
\text { minerals }\end{array}$ & $\begin{array}{l}\text { Iron oxy- } \\
\text { hydroxides }\end{array}$ & $\begin{array}{c}\text { Sulfide } \\
\text { minerals }\end{array}$ & $\begin{array}{l}\text { Iron oxy- } \\
\text { hydroxides }\end{array}$ \\
\hline \multicolumn{7}{|l|}{ Oxic } \\
\hline & \multicolumn{2}{|l|}{ Iron reducing } & & & & \\
\hline & & Sulfate reducing & & & & \\
\hline
\end{tabular}




\section{Methods}

Boreholes were drilled to retrieve samples of the aquifer materials (solid phase). At site 1, three boreholes were drilled by personnel from the USGS Wisconsin Water Science Center. A 4 1/4-in. hollow-stem auger was used to drill through the glacial material, and split-spoon samples were collected from land surface to about $65 \mathrm{ft}$ (Appendix 1A). A 3-in. continuous core of bedrock from 73 to $177 \mathrm{ft}$ was retrieved by use of a wireline core-barrel system (Appendix 1B). At site 2, drilling was done by a rotosonic rig by personnel from a consulting engineering firm. A 4-in.-diameter continuous core was retrieved from land surface to $119 \mathrm{ft}$ (Appendix 2). Cores of carbonate bedrock and split-spoon samples of glacial deposits were described in the field by geologists from the Ohio Department of Natural Resources, Division of Geological Survey. Subsamples of the solid phase were collected approximately every foot. Samples were preserved by air drying, and the sample containers were purged with nitrogen gas and sealed with tape for storage and shipment.

In all, 70 solid-phase samples were analyzed for bulk composition of 42 major, minor, and trace elements at a contract laboratory used by the USGS Geologic Discipline. Samples were ground, digested with multiple acids, and analyzed by inductively coupled plasma-atomic emission spectrometry (ICP-AES) and inductively coupled plasma-mass spectrometry (ICP-MS) (Briggs and Meier, 2002). Samples also were analyzed for total sulfur and total carbon by use of automated analyzers and for carbonate carbon by use of coulometric titration. Four replicate solid-phase samples were analyzed for bulk elemental composition, and concentrations of arsenic, iron, sulfate, and organic carbon were judged to be similar to those of the environmental samples.

The mineralogy of selected horizons was analyzed from polished thin sections. Transmitted and reflected light microscopy were used to make mineral point counts. In addition, polished thin sections of core samples were examined with a JOEL 5800LV scanning electron microscope (SEM) equipped with an Oxford ISIS energy-dispersive X-ray (EDS) detector to determine basic mineralogy, identify textural features, and obtain qualitative to semiquantitative analyses of trace- and minor-element content and distribution in minerals, especially pyrite. Element distribution maps of the thin sections, which show the spatial distribution and intensity of individual elements, were generated from both the SEM and a JEOL JXA8900 electron probe microanalyzer (EPMA). Warm colors (red to yellow) in the element distribution maps indicate relative high concentrations of an element, and cool colors (green to blue) indicate lower concentrations. The SEM and EPMA both have excellent spatial resolution (better than a few micrometers), but differ in terms of detection limits for arsenic and other heavy trace elements, such as nickel; the EPMA has a detection limit of 500-1,000 ppm, and the SEM has a detection limit of 1,000 ppm.

Six water-producing horizons were selected for further analysis on the basis of visual inspection of the solid-phase cores and split-spoon samples. Water samples from these six horizons were collected from five 2-in. monitor wells installed for this study and one domestic well installed in 1977 (table 3); sampling the domestic well was not optimal but was considered acceptable because the well was within $150 \mathrm{ft}$ of the coresample collection site.

Table 3. Characteristics of sampled wells.

[BLS, below land surface; NA, not available]

\begin{tabular}{|c|c|c|c|c|c|}
\hline Well identifier & $\begin{array}{c}\text { Horizon; aquifer } \\
\text { type }\end{array}$ & $\begin{array}{c}\text { Screened } \\
\text { interval, } \\
\text { in feet BLS }\end{array}$ & $\begin{array}{l}\text { Water level, } \\
\text { in feet BLS }\end{array}$ & $\begin{array}{l}\text { Date water level } \\
\text { measured }\end{array}$ & $\begin{array}{l}\text { Well type; } \\
\text { installation } \\
\text { method }\end{array}$ \\
\hline \multicolumn{6}{|c|}{ Site 1 , land surface altitude $=1,147$ feet } \\
\hline 395430084415400 & 1A; glacial & $30-35$ & 24.29 & 09-02-2004 & Monitor; auger \\
\hline 395429084415500 & 1B; glacial & $47-52$ & 25.34 & 09-01-2004 & Monitor; auger \\
\hline 395429084415600 & 1C; carbonate & 83-88 & 25.79 & 09-02-2004 & Monitor; rotary \\
\hline \multicolumn{6}{|c|}{ Site 2, land-surface altitude = 1,132 feet } \\
\hline 395236084403600 & 2A; glacial & $32-37$ & 16.64 & 08-31-2004 & Monitor; rotosonic \\
\hline 395236084403601 & 2B; glacial & $75-80$ & 17.48 & 08-31-2004 & Monitor; rotosonic \\
\hline 395237084403600 & 2C; glacial & $90-93^{1}$ & 17.18 & 09-01-2004 & Domestic; NA \\
\hline
\end{tabular}

\footnotetext{
${ }^{1}$ Estimate based on driller's log for domestic well.
} 
Ground-water samples were collected in late August and early September 2004. Procedures for well purging, sample collection and preservation, and quality assurance were consistent with standard protocols of the USGS (U.S. Geological Survey, variously dated). Field determinations were made for $\mathrm{pH}$, dissolved oxygen, specific conductance, and temperature (with a multiparameter instrument and a flowthrough chamber), alkalinity (by titration), turbidity (with a turbidimeter), and sulfide and ferrous iron (with a field spectrophotometer). Samples were sent to the USGS National Water-Quality Laboratory for analysis of major ions, trace elements, nutrients, dissolved organic carbon, and arsenic speciation (Fishman, 1993; Brenton and Arnette, 1993; Garbarino, 1999; Garbarino and others, 2002). The water-quality data were published in the USGS annual water-data report for Ohio (Shindel and others, 2005).

Four quality-control ground-water samples were collected and analyzed. An equipment blank was collected just before sampling and was analyzed for major ions, nutrients, and trace elements. During sampling, a field blank and replicate were analyzed for total arsenic. A field spike and replicate were analyzed for arsenic species. None of the blanks showed any indication of contamination. Replicates were within acceptable limits (1-6 percent). Field-spike results showed recoveries of 80 to 83 percent for arsenic species, which was considered acceptable.

Redox processes were assessed by means of a framework of threshold concentrations of five commonly measured waterquality constituents considered to be redox indicator speciesdissolved oxygen, nitrate, manganese, iron, and sulfate (table 4) (Paschke, 2007; McMahon and Chapelle, 2008). In addition, for samples classified as "iron or sulfate reducing," concentration ratios of dissolved ferrous iron to sulfide were used to estimate the relative predominance of iron reduction and sulfate reduction. $\mathrm{Fe} / \mathrm{S}$ mass ratios less than 0.3 indicate that sulfate reduction is predominant, whereas $\mathrm{Fe} / \mathrm{S}$ ratios greater than 10 indicate that (1) iron reduction is predominant or (2) conditions have shifted from iron reduction to sulfate reduction even though iron has not been removed from solution (Chapelle and others, in press).

Chemical-equilibrium modeling was used to test hypotheses about interactions between the ground water and the solid phase. Speciation and mass-balance modeling were done by use of PHREEQC version 2 (Parkhurst and Appelo, 1999). Speciation modeling requires input of ground-water composition, including temperature, $\mathrm{pH}$, concentrations of elements and (or) element valence states, and a redox indicator. The model calculates the distribution of aqueous species and mineral saturation indices. Saturation indices (SI) are used to indicate the saturation state of a ground-water sample with respect to a particular set of minerals. When the ion activity product (IAP) of a ground-water sample is equal to the solubility product (Ksp) of a given mineral at a given temperature, SI equals zero, meaning that the water is in thermodynamic equilibrium with respect to the mineral. If SI is greater than zero, the mineral might precipitate, but it cannot dissolve. If SI is less than zero, the mineral might dissolve but it cannot precipitate.

Mass-balance modeling was done by use of the inverse modeling module of PHREEQC, version 2. Input to the model includes (1) the water chemistry of two or more ground-water samples assumed to be from the same flow path and (2) the presumed composition of the solid phase and gases. Results from the model show the mass transfer among solid and gas reactants that can account for the observed difference in ground-water composition. Positive mass transfers indicate mineral dissolution, and negative mass transfers indicate mineral precipitation.

Table 4. Threshold concentrations of water-quality constituents for assessing redox processes.

[Modified from Paschke, 2007, and McMahon and Chapelle, 2008; <, less than; >, greater than or equal to; --, constituent concentration not specified]

\begin{tabular}{|c|c|c|c|c|c|}
\hline \multirow[b]{2}{*}{ Redox process } & \multicolumn{5}{|c|}{ Concentration, in milligrams per liter } \\
\hline & $\begin{array}{l}\text { Dissolved oxy- } \\
\text { gen }\left(\mathrm{O}_{2}\right)\end{array}$ & $\begin{array}{l}\text { Nitrate } \\
\left(\mathrm{NO}_{3}^{-}-\mathrm{N}\right)\end{array}$ & $\begin{array}{c}\text { Manganese } \\
\left(\mathrm{Mn}^{2+}\right)\end{array}$ & $\begin{array}{l}\text { Iron } \\
\left(\mathrm{Fe}^{2+}\right)\end{array}$ & $\begin{array}{l}\text { Sulfate } \\
\left(\mathrm{SO}_{4}{ }^{2-}\right)\end{array}$ \\
\hline Oxygen reduction & $>0.5$ & -- & $<0.5$ & $<0.1$ & -- \\
\hline Nitrate reduction & $<0.5$ & $>0.5$ & $<0.5$ & $<0.1$ & -- \\
\hline Manganese reduction & $<0.5$ & $<0.5$ & $>0.5$ & $<0.1$ & -- \\
\hline $\begin{array}{l}\text { Iron or sulfate reduction } \\
\qquad\left(\mathrm{Fe}(\mathrm{III}) / \mathrm{SO}_{4}{ }^{2-}\right)\end{array}$ & $<0.5$ & $<0.5$ & -- & $>0.1$ & $>0.5$ \\
\hline Methanogenesis & $<0.5$ & $<0.5$ & -- & $>0.1$ & $<0.5$ \\
\hline Mixed & \multicolumn{5}{|c|}{ Criteria for more than one redox processes are met } \\
\hline
\end{tabular}




\section{Solid-Phase Characteristics}

The term "solid phase" refers to the aquifer materials, either unconsolidated glacial deposits or bedrock. Characteristics of the solid phase were described at several scales: visual descriptions of cores, the elemental composition of ground-up samples, and microscopic analysis of polished thin sections. Figures in this report show data from a limited depth interval (20 to $120 \mathrm{ft}$ ) to facilitate visual comparisons between the two study sites. However, the appendixes include data from the entire range of depths sampled.

\section{Stratigraphy}

Simplified stratigraphic columns for sites 1 and 2 are presented in figures 2 and 3 , respectively. The figures are based on detailed core descriptions (Appendixes 1 and 2), supplemented by drillers' notes and core photographs.

\section{Site 1}

Glacial deposits at site 1 were about $68 \mathrm{ft}$ thick. Deposits to a depth of $57.5 \mathrm{ft}$ were silty, sandy till with interbeds of sand and (or) gravel. The sediments were calcareous and were predominantly gray, grayish-brown, or brownish-gray. The coarse-grained deposits were predominantly carbonate rock fragments, along with a complex mix of igneous and sedimentary rock fragments and quartz and feldspar grains.

Deposits from 57.5 to $59 \mathrm{ft}$ were fine-grained, noncalcareous, and yellow- or orangebrown with some gray mottles. This is a probable paleosol at the contact between Wisconsinan and Illinoian glacial deposits. The contact between glacial deposits and bedrock was estimated to be at about $68 \mathrm{ft}$. There was some evidence that this zone was enriched in organic carbon; the last sample of glacial material (from $67 \mathrm{ft}$ ) was dark gray, and the first piece of bedrock (from $73 \mathrm{ft}$ ) had petroleum tar stains.

Bedrock was cored from $73 \mathrm{ft}$ to $177 \mathrm{ft}$, which accounts for almost the entire section of the Lockport Dolomite (73-156 ft) and Laurel Dolomite (156-177 ft) (Slucher and others, 2006). The Lockport Dolomite was pale gray to pale yellow dolomite with vuggy or intercrystalline porosity and fine to coarse texture. Also noted were argillaceous laminae and high-angle fractures. The Laurel Dolomite was predominantly limestone with dolomite with chert. At $77 \mathrm{ft}$ was a 6 -in. zone of unconsolidated material composed of clay and clasts of dolomite. The deposits appeared to be cavity fill because competent bedrock was above and below the unconsolidated material.

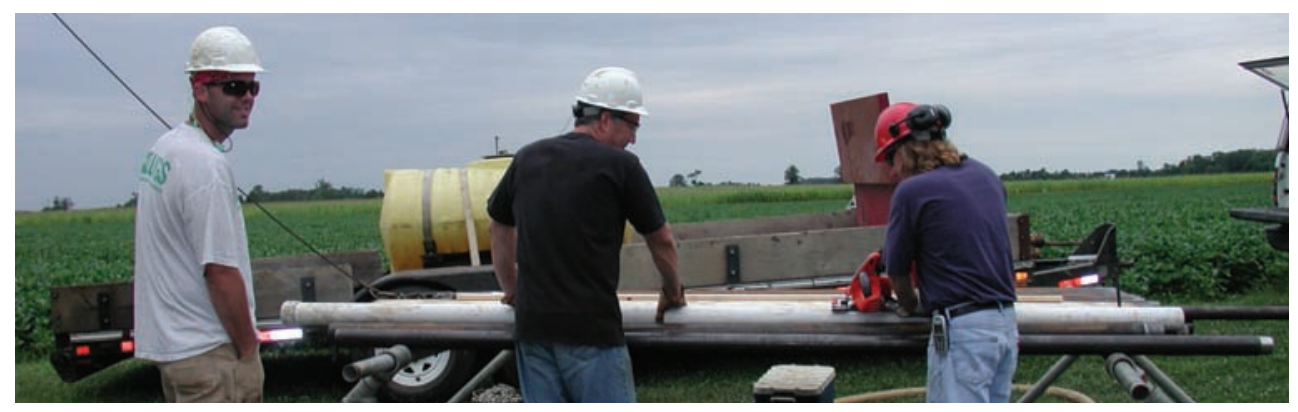

Report coauthors Tom Schumann (center) and Bruce Pletsch (right) cut rock cores while USGS hydrologic technician Brent Olson (left) looks on. (Phototograph by Mary Ann Thomas, U.S. Geolgocal Survey.) 


\section{SITE 1}

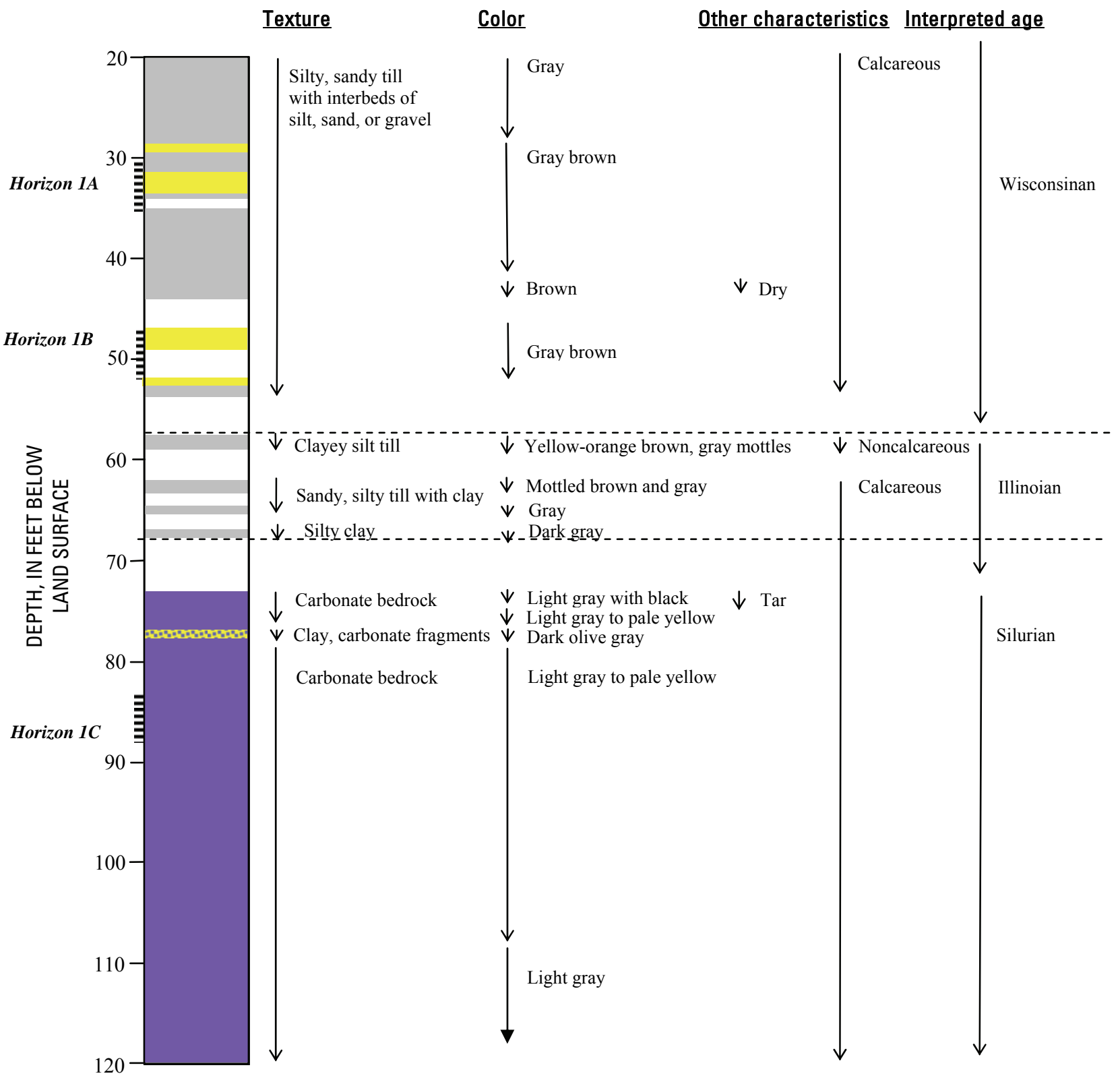

\section{EXPLANATION}

Stratigraphy

Silt, till or clay

Sand or gravel

Carbonate bedrock

Figure 2. Simplified stratigraphic column, site 1 in northern Preble County, Ohio. 


\section{Site 2}

At site 2, the glacial deposits were $110 \mathrm{ft}$ thick. From 20 to $60 \mathrm{ft}$, the glacial deposits were predominantly silty, sandy till with interbeds of sand and gravel. The sediments were calcareous and were predominantly gray, brown, or grayish-brown; coarse-grained deposits were predominantly carbonate bedrock fragments. From 60 to about $80 \mathrm{ft}$ was well-sorted sand, presumably valley fill. A sample from $77 \mathrm{ft}$ had a higher proportion of quartz and feldspar grains than carbonate rock fragments. From about 80 to $90 \mathrm{ft}$, the deposits were clayey silt that is presumed to be lacustrine.

From about 90 to $92 \mathrm{ft}$, the glacial deposits were organic-rich silt and gravel, which is a probable paleosol near the boundary between Wisconsinan and Illinoian deposits. Hard, dry, dark reddish-brown sediment at 103 to $107 \mathrm{ft}$ was interpreted as a second Illinoian paleosol. Altered bedrock was at 107 to $110 \mathrm{ft}$, and competent Lockport Dolomite bedrock was cored from 110 to $120 \mathrm{ft}$.

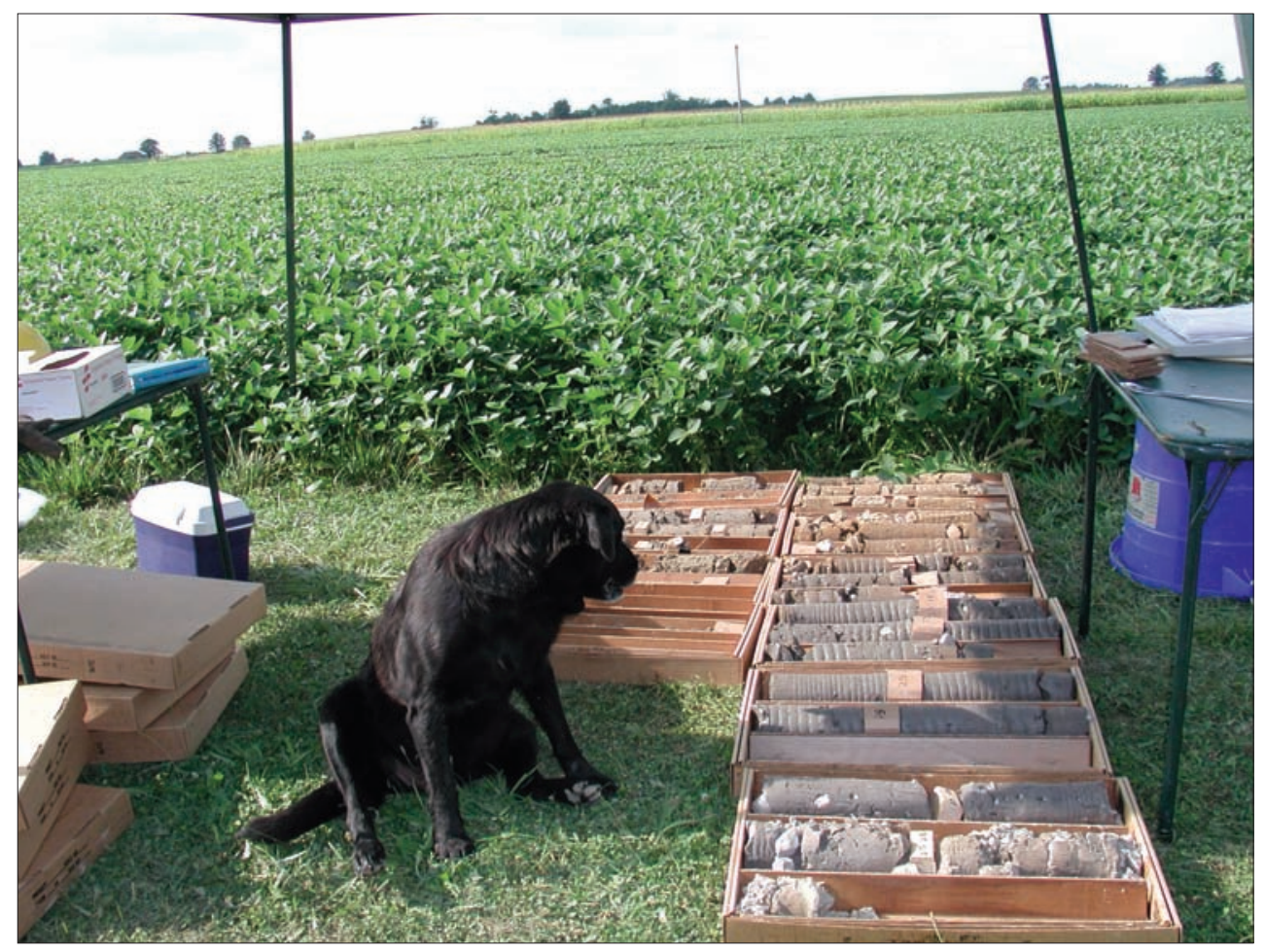

The resident dog at site 1 scans split-spoon samples of glacial deposits that have been boxed for shipment to the Ohio Department of Natural Resources, Division of Geological Survey's Horace R. Collins Laboratory near Columbus for archiving. (Photo by Mary Ann Thomas, U.S. Geological Survey.) 
SITE 2

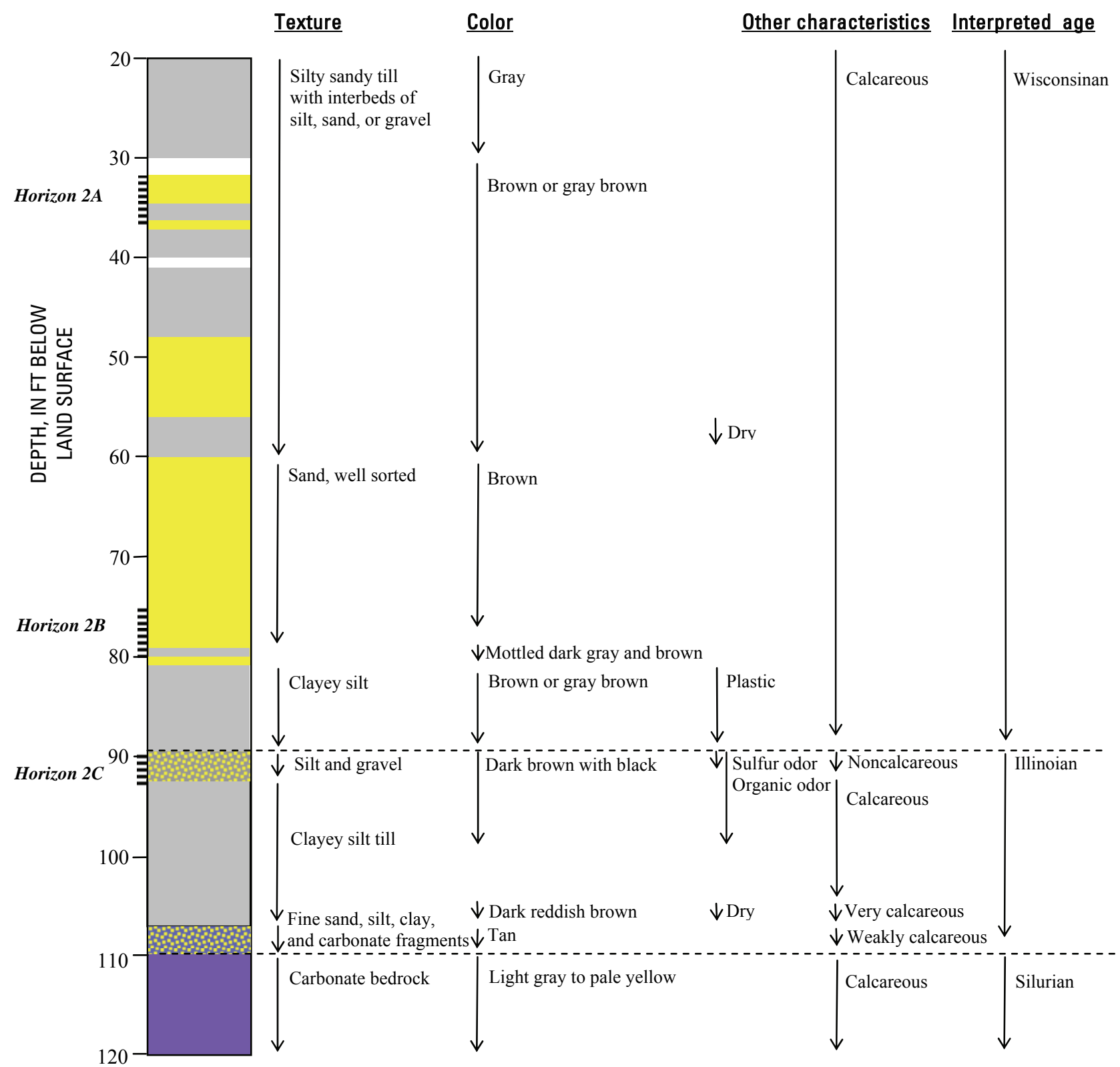

\section{EXPLANATION}

\section{Stratigraphy}

Silt, till or clay

Sand or gravel

Carbonate bedrock

\author{
Silt and gravel \\ Fine sand, silt, clay, and carbonate fragments \\ No sample recovered
}

Figure 3. Simplified stratigraphic column, site 2 in northern Preble County, Ohio. 


\section{Bulk Elemental Composition}

Samples of the solid-phase materials were ground, treated with acid, and analyzed for bulk concentrations of 42 inorganic constituents and organic carbon (Appendix 3). Arsenic concentrations ranged from less than 1 to $42 \mathrm{mg} / \mathrm{kg}$ (table 5). The median arsenic concentration for glacial deposits (6 mg/ $\mathrm{kg}$ ) was higher than for bedrock ( $<\mathrm{lmg} / \mathrm{kg})$. For glacial deposits, the median arsenic concentration of fine-grained material $(8.5 \mathrm{mg} / \mathrm{kg})$ was higher than for coarse-grained $(4.5 \mathrm{mg} / \mathrm{kg})$. In general, arsenic concentrations from the study area were within the range of typical values for unconsolidated deposits and limestone/dolomite listed in table 1.

At both sites, the highest solid-phase arsenic concentrations were from a roughly similar stratigraphic position, a transition zone that extends from just above the Wisconsinan/ Illinoian contact to just below the Pleistocene/Silurian contact (fig. 4). Also, at both sites, the concentrations of arsenic and iron show similar patterns of variation. This is consistent with the idea that the major sources of arsenic are pyrite and iron oxides, both of which contain iron. Comparison of depth relations with sulfur and organic carbon yield additional qualitative clues as to the mineral source of arsenic.

\section{Site 1}

From site 1, 16 samples of glacial deposits were analyzed for bulk composition (Appendix 3A). Wisconsinan deposits had arsenic concentrations of 2 to $6 \mathrm{mg} / \mathrm{kg}$. Illinoian deposits, all of which were fine-grained, had arsenic concentrations of 9 to $20 \mathrm{mg} / \mathrm{kg}$. For glacial deposits, the highest arsenic concentrations were from the leached paleosol just below the Wisconsinan/Illinoian contact. In this horizon, the concentration of iron was relatively high and concentrations of sulfur and organic carbon were relatively low, indicating that arsenic might be associated with iron oxides within this weathered horizon.
Twenty samples of carbonate bedrock were analyzed between 73 and $177 \mathrm{ft}$ (Appendix 3A). Seventy-five percent of samples had arsenic concentrations less than $1 \mathrm{mg} / \mathrm{kg}$, and 95 percent had concentrations less than or equal to $4 \mathrm{mg} / \mathrm{kg}$. Arsenic concentrations in carbonate bedrock were generally lower than in glacial deposits, as were concentrations of iron, sulfur, and organic carbon. One very high concentration of arsenic was detected in the unconsolidated horizon within bedrock at $77 \mathrm{ft}$. This zone had extreme outlier concentrations of arsenic (42 mg/kg), as well as zinc (571 mg/kg), lead (47 mg/ $\mathrm{kg}$ ), nickel (64 mg/kg), and strontium (657 mg/kg). This zone is hereafter referred to as the "unconsolidated bedrock zone."

\section{Site 2}

From site 2, 26 samples of glacial deposits were analyzed for bulk composition (Appendix 3B). Arsenic concentrations were 4 to $14 \mathrm{mg} / \mathrm{kg}$ in Wisconsinan deposits and 5 to $11 \mathrm{mg} /$ $\mathrm{kg}$ in Illinoian deposits. At this site, the maximum arsenic concentration was detected in fine-grained glacial deposits just above the Wisconsinan/Illinoian contact. This horizon also had relatively high concentrations of sulfur and organic carbon. The second highest arsenic concentration was just above the Illinoian/Silurian contact, in a leached paleosol. High concentrations of iron and low concentrations of sulfur and organic carbon suggest that this might be a weathered zone in which arsenic is associated with iron oxides. Four samples of carbonate bedrock were analyzed between 110 and $120 \mathrm{ft}$, and all had arsenic concentrations less than $1 \mathrm{mg} / \mathrm{kg}$.

At both sites, the highest solid-phase arsenic concentrations were from a roughly similar stratigraphic position, a transition zone that extends from just above the Wisconsinan/Illinoian contact to just below the Pleistocene/Silurian contact. At both sites, the transition zone included (1) a leached paleosol where arsenic might be associated with iron oxides and (2) a horizon with relatively high concentrations of organic carbon.

Table 5. Arsenic concentrations in solid-phase samples, northern Preble County, Ohio.

[mg/kg, milligrams per kilogram (equivalent to parts per million)]

\begin{tabular}{cccc}
\multicolumn{1}{c}{ Type of solid-phase material } & Number of \\
samples & & \multicolumn{2}{c}{$\begin{array}{c}\text { Solid-phase arsenic concentration } \\
\text { (mg/kg) }\end{array}$} \\
\cline { 3 - 4 } Glacial deposits, all samples & 42 & Median & Range \\
Predominantly coarse grained & 20 & 6 & $2-20$ \\
Predominantly fine grained & 22 & 4.5 & $2-20$ \\
Lockport Dolomite, all samples & & $<1$ & $<1-42$ \\
Unconsolidated bedrock zone, site 1 & 24 & - & 42 \\
Excluding unconsolidated bedrock zone, site 1 & 1 & $<1$ & $<1-4$ \\
\hline
\end{tabular}



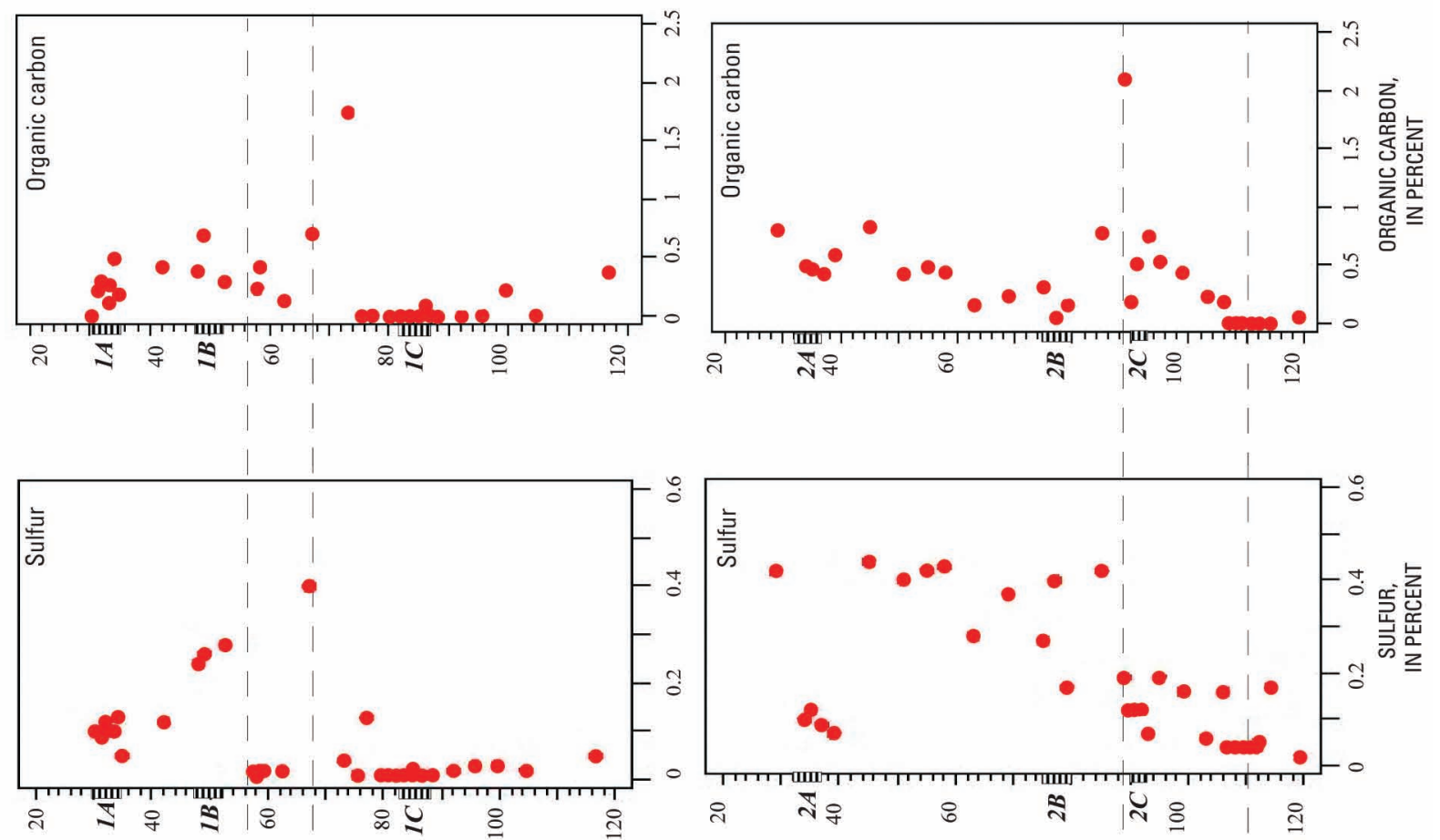

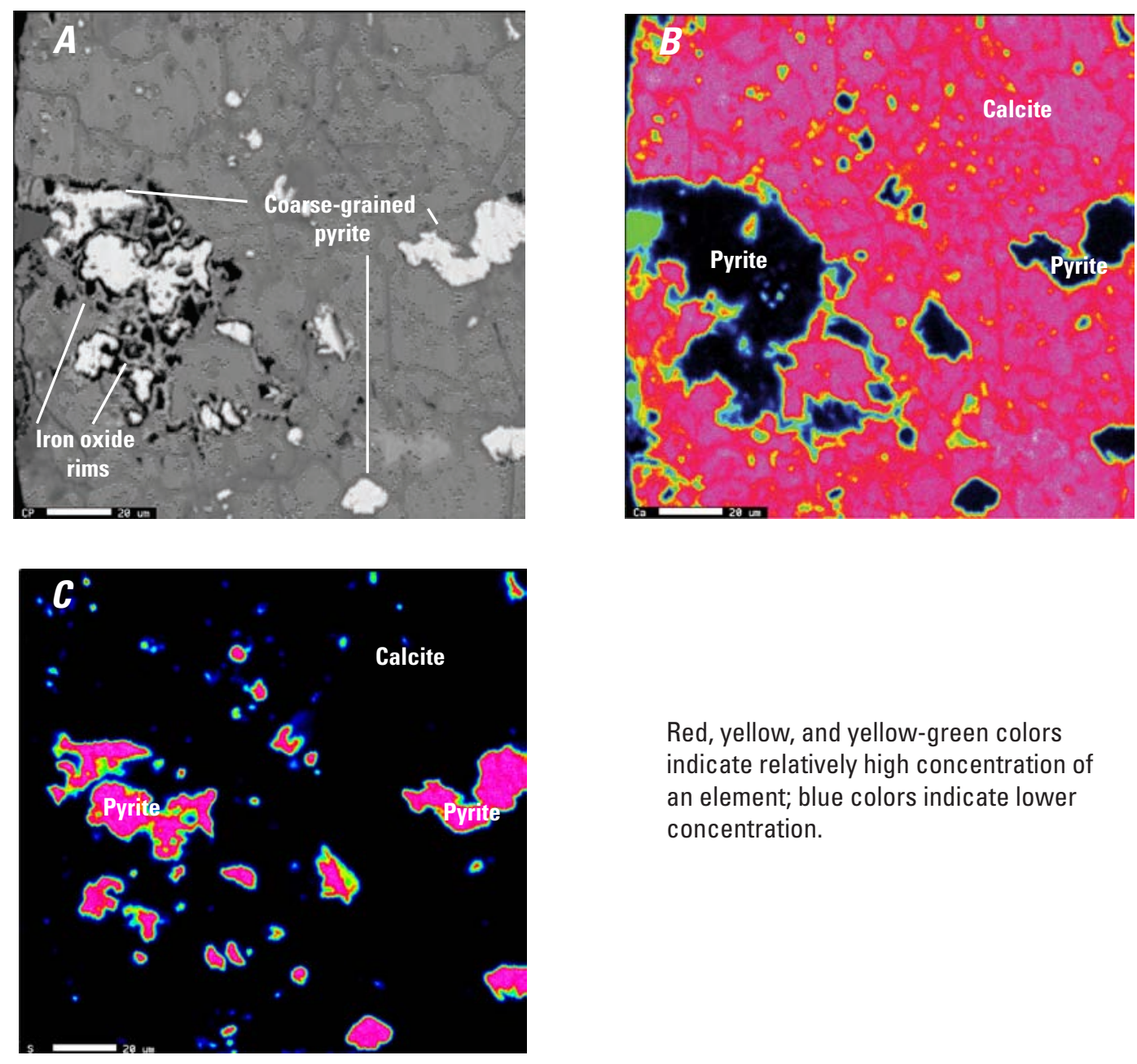

Red, yellow, and yellow-green colors indicate relatively high concentration of an element; blue colors indicate lower concentration.
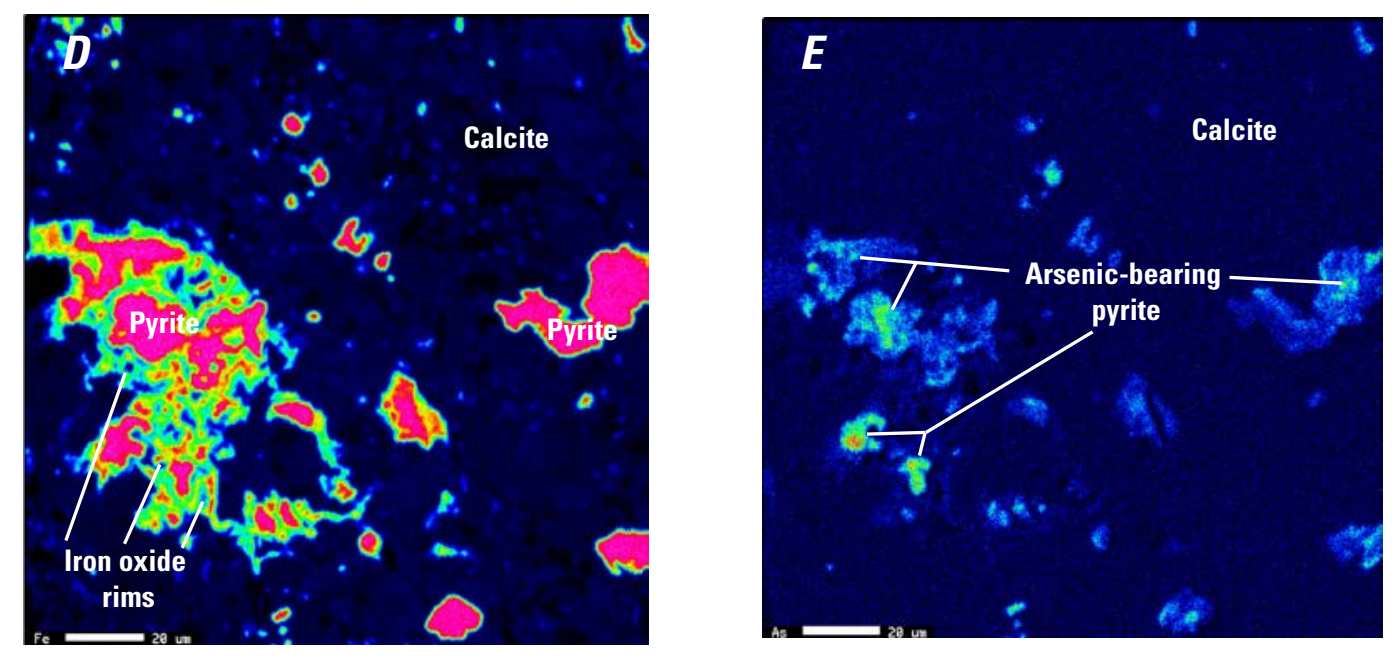

Figure 5. Micrograph of a sample from horizon 1A (small scale bars in lower left corners of images represent 20 micrometers). $A$, Backscatter image of a calcite clast with partially dissolved pyrite. Remant iron-oxide rims outline the former extent of the pyrite grains. $B$, Element distribution map of calcium showing that pyrite occurs within a carbonate clast. $C$, Element distribution map of sulfur showing pyrite distribution. $D$, Element distribution map of iron showing pyrite and remnant iron-oxide rims. $E$, Element distribution map of arsenic showing that arsenic is not evenly distributed; higher concentrations are in core areas of pyrite grains. Arsenic was also detected in the iron-oxide rims. 


\section{Residence of Arsenic in Sulfide Minerals}

Microanalytical techniques were used to examine the mineralogy of seven samples-six samples from the waterproducing horizons and one sample from the unconsolidated bedrock zone (Appendix 4). The emphasis was on examining the residence of arsenic in sulfide minerals. There were several morphological forms of sulfide minerals, indicating multiple generations of formation. The sulfide minerals also displayed multiple textures, indicating varied weathering intensities. The most abundant sulfide mineral was framboidal pyrite, a spheroidal form composed of aggregates of microcrystalline pyrite. Framboidal pyrite was found in every thin section, but arsenic was not detected in framboidal pyrite at concentrations above the detection limit of the SEM. However, other types of sulfide minerals had arsenic concentrations that ranged from 0.3 to 4.0 weight percent.

A sample from horizon 1A was examined with the SEM and EPMA. The sample was composed primarily of carbonate fragments, along with igneous rock fragments and liberated grains of quartz, feldspar, and pyroxene (Appendix 4). A clast of micritic carbonate rock contained coarse-grained pyrite in which arsenic was detected at a concentration of up to 2.6 weight percent (fig. 5 , facing page). Pyrite within the rock fragment showed signs of weathering; the arsenic-bearing pyrite was partially dissolved, and the former boundaries of the pyrite grains were outlined by skeletal iron oxides. The iron-oxide rims also contained arsenic (although it is difficult to see them in figure 5E) and showed evidence of partial dissolution.

A sample from horizon 1B was examined with the SEM and EPMA. The sample was composed mainly of carbonate rock fragments, along with igneous and sedimentary rock fragments and liberated grains of quartz and feldspar (Appendix 4). A clast of quartz siltstone included two forms of arsenicbearing sulfide minerals: (1) coarsely crystalline pyrite with an arsenic concentration of up to 0.4 weight percent and (2) a very fine-grained nickel-arsenic sulfide mineral, possibly gersdorffite (fig. 6). Sphalerite, a zinc sulfide mineral, also was noted. Iron oxides were not detected in association with the arsenic-bearing sulfide minerals.

A sample of the Lockport Dolomite from horizon 1C was examined with the SEM. The sample contained both ironbearing and nonferroan dolomite (Appendix 4). Pyrite was found as microcrystalline cubes and as spheroidal framboids. It appears that iron oxides replaced a coarsely crystalline sulfide mineral within the dolomite. Arsenic was not detected at the limits of the SEM.

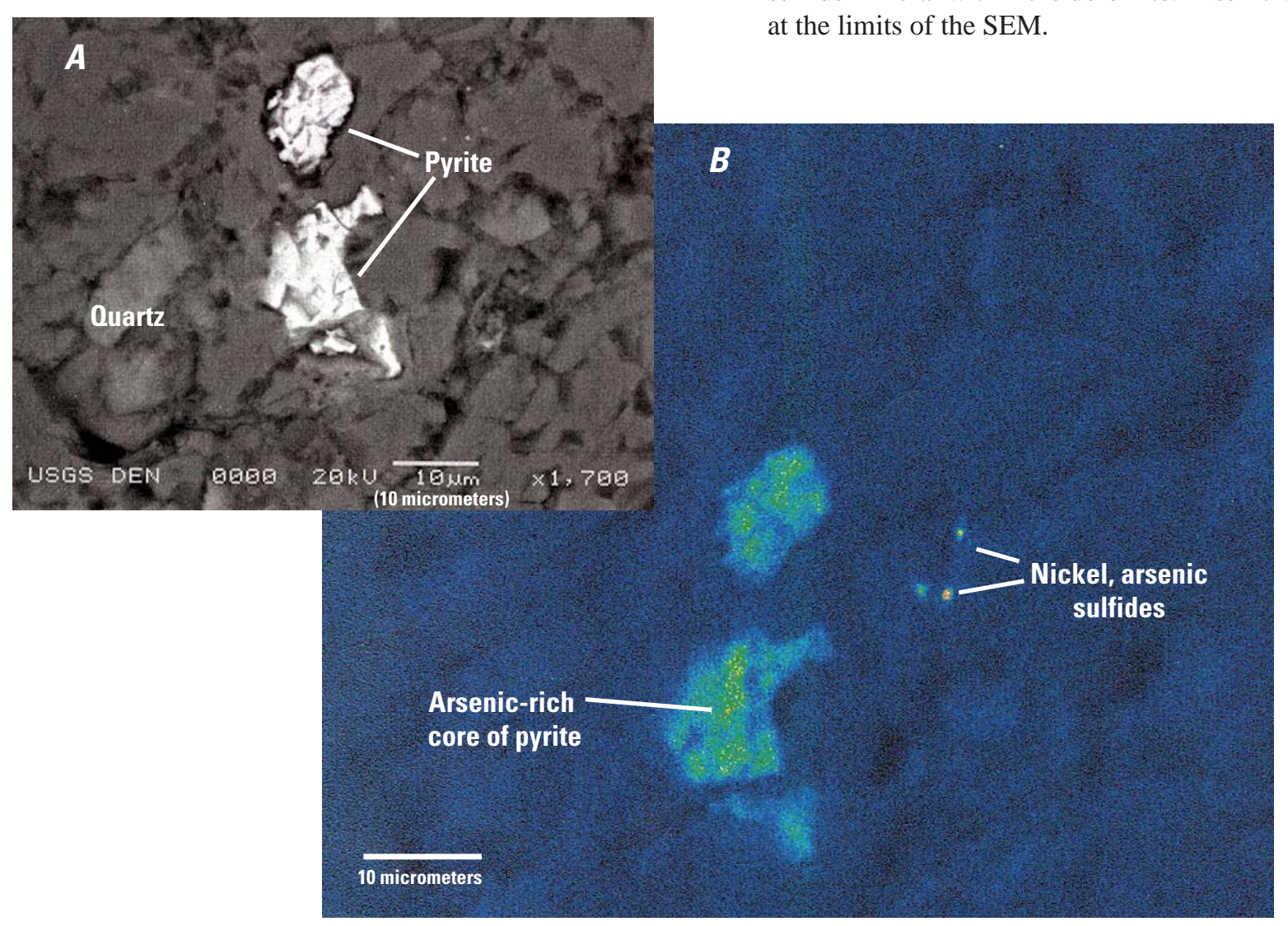

Figure 6. Micrograph of a sample from horizon 1B. $A$, Coarse-grained pyrite in a clast of quartz siltstone. $B$, Element distribution map of arsenic showing two forms of arsenic-bearing sulfide minerals: coarse-grained pyrite and fine-grained arsenic-nickel sulfides. Reds, yellows, and greens indicate relatively high concentration of arsenic, and blues indicate lower concentration. 
A sample from the unconsolidated bedrock zone at $77 \mathrm{ft}$ at site 1 was examined with the SEM. The sample was composed of dolomite and illitic clay, with a minor amount of igneous rock fragments (Appendix 4). The dolomite rhombs were deeply embayed and etched, and they floated in a clay matrix (fig. 7). Arsenic was detected at a concentration of up to 4 weight percent in a nickel-arsenic sulfide mineral (possibly gersdorffite) that occurs exclusively within the clay. Nickel is concentrated in the coarsely crystalline core, whereas arsenic is more evenly distributed.

A sample from horizon 2A was examined with the SEM. The sample was composed mainly of carbonate rock fragments along with sedimentary and igneous rock fragments and liberated grains of quartz and feldspar (Appendix 4). Framboidal pyrite was abundant in the thin section, but arsenic was not detected at the limits of the SEM. Skeletal iron oxides were present in the dolomite fragments but not in association with remnants of arsenic-bearing pyrite, as in horizon $1 \mathrm{~A}$.

A thin section from horizon $2 \mathrm{~B}$ was examined with the SEM and EPMA. The sample was mainly composed of liberated grains of quartz and feldspar along with igneous, car- bonate, and other sedimentary rock fragments (Appendix 4). Figure 8 shows a shale fragment in which framboidal pyrite appears to have replaced a shell or bone fragment. Arsenic was not detected in the framboidal pyrite, but it was detected in a second generation of coarse-grained pyrite that coats the framboidal pyrite. Arsenic concentrations in the coarse-grained pyrite were up to 1 weight percent.

A sample from horizon $2 \mathrm{C}$ was examined with the SEM. The sample was very poorly sorted, with pebble-sized quartz, feldspar, and rounded carbonate clasts in a matrix of micritic calcite and silt-sized quartz grains (Appendix 4). The sample also had large fragments of cellular organic material that had been replaced by massive arsenic-bearing pyrite and iron oxides (fig. 9). The arsenic content of the pyrite was 0.3 weight percent, and pyrite made up 4 percent of the total sample. An element-distribution map shows that arsenic is evenly distributed throughout the massive pyrite.
$\boldsymbol{A}$

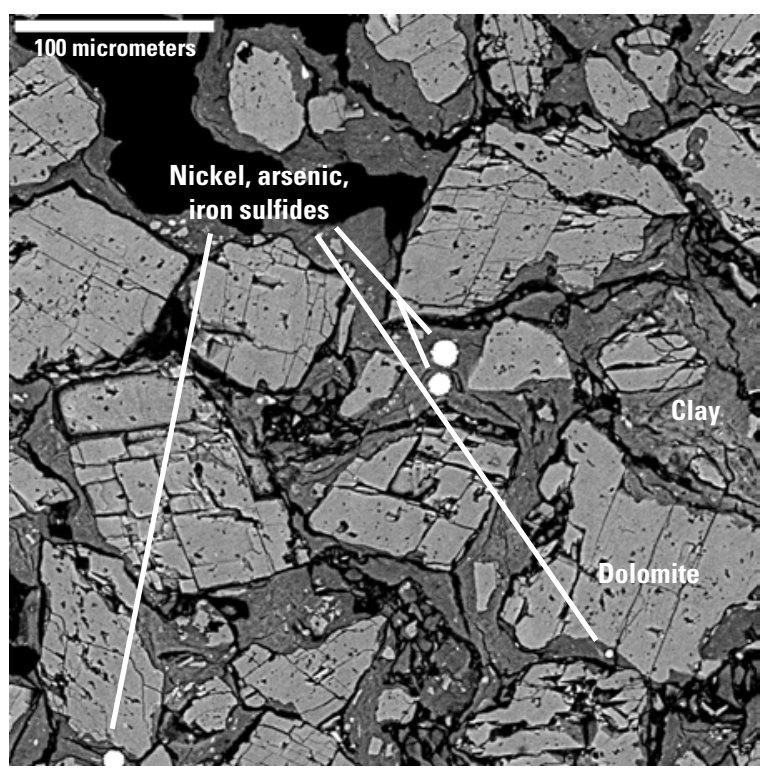

B

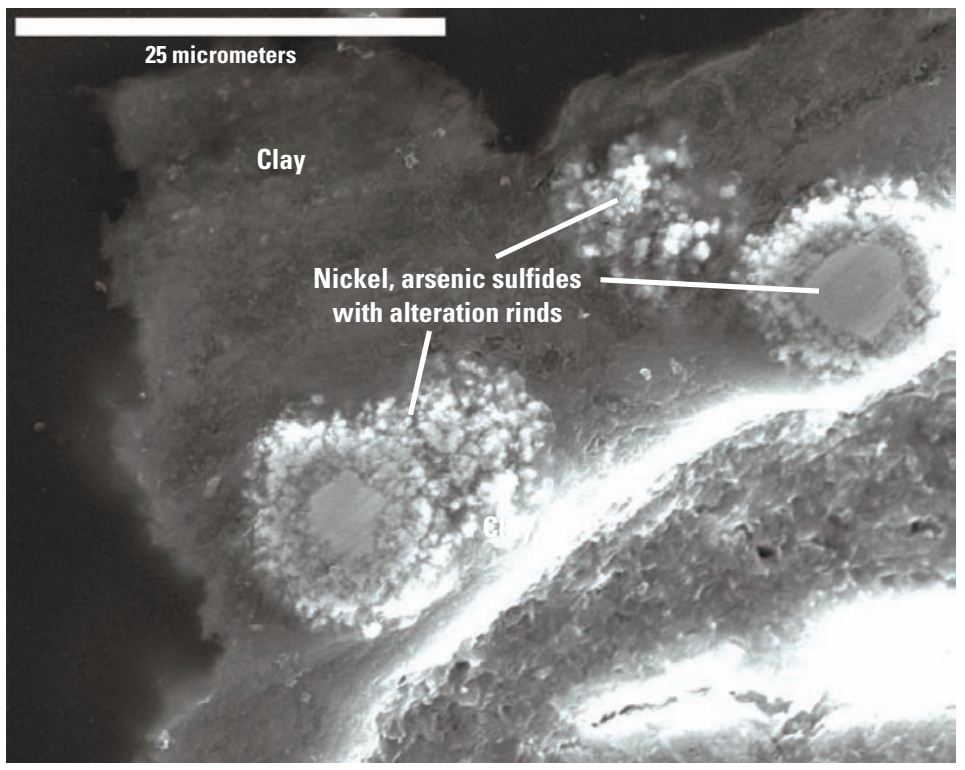

Figure 7. Micrograph of a sample from the unconsolidated bedrock zone at site 1. $A$, Etched dolomite rhombs in a clay matrix. $B$, Enlarged view of arsenic- and nickel-bearing sulfides in the clay matrix. 

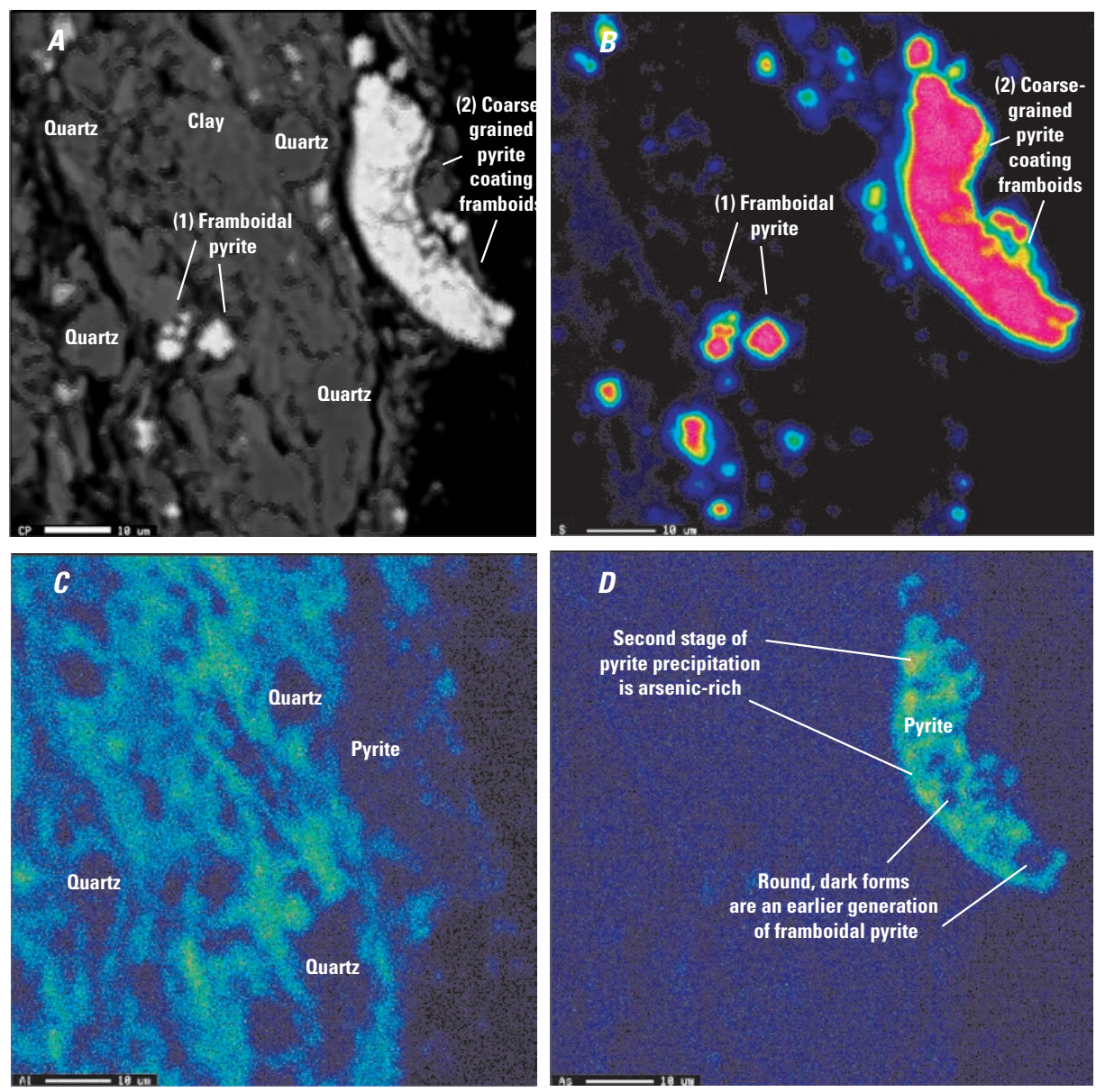

Figure 8. Micrograph of a sample from horizon 2B (small scale bars in lower left corners of images represent 10 micrometers). A, Backscatter image of a shaly clast with quartz, clay, framboidal pyrite, and shell or bone material replaced by pyrite. An early generation of (1) framboidal pyrite is coated by (2) a coarse-grained pyrite. $B$, Element distribution map of sulfur showing different generations of pyrite. $C$, Element distribution map of aluminum showing clay distributions in shaly clast. $D$, Element distribution map of arsenic showing that framboidal pyrite does not contain arsenic, whereas the second generation of coarse-grained pyrite is arsenic-rich.
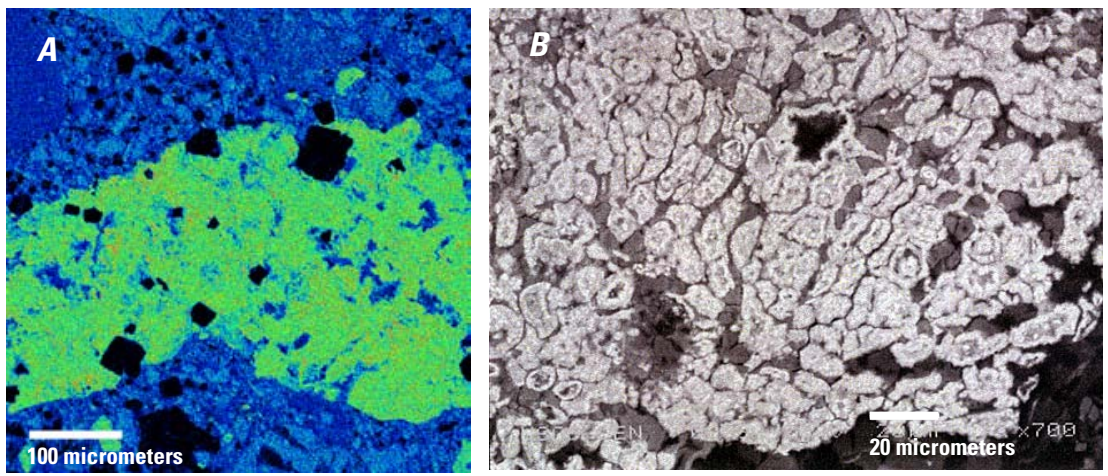

Figure 9. Micrograph of a sample from horizon 2C. $A$, Element distribution map of arsenic showing organic material replaced by pyrite; arsenic is evenly distributed throughout the pyrite. Reds, yellows, and greens indicate relatively high concentration of arsenic, and blues indicate lower concentration. Black areas are dolomite rhombs. $B$, Enlarged area of organic material replaced by pyrite. Note that the cellular structure of the organic matter is retained. 


\section{Ground-Water Quality}

Ground-water samples from six horizons were analyzed for $\mathrm{pH}$, alkalinity, specific conductance, dissolved oxygen (DO), dissolved organic carbon (DOC), major ions, nutrients, and trace elements. Selected water-quality constituents and properties are presented in table 6, and the entire dataset is available in Shindel and others (2005). Redox conditions were assessed using threshold concentrations of DO, nitrate, manganese, iron, and sulfate (table 4) (Paschke, 2007; McMahon and Chapelle, 2008). In addition, for samples classified as "iron or sulfate reducing," mass ratios of ferrous iron to sulfide (Fe/S) were used to assess which of the two redox processes is predominant (Chapelle and others, in press).

Two of the six ground-water samples had arsenic concentrations greater than the USEPA MCL of $10 \mu \mathrm{g} / \mathrm{L}$ - horizon 1A had a dissolved arsenic concentration of $13 \mu \mathrm{g} / \mathrm{L}$, and horizon 2C had a dissolved arsenic concentration of $51 \mu \mathrm{g} / \mathrm{L}$. The other four samples had arsenic concentrations of 0.2 to $6 \mu \mathrm{g} / \mathrm{L}$. Arsenite and arsenate species were present in all six water samples. Arsenite, the reduced form, is more mobile in ground water and considered to be more toxic to humans. Arsenite was the predominant species in the two horizons with dissolved arsenic concentrations above the MCL, 1A and 2C. For the other four horizons, concentrations of arsenite were less than, or similar to, concentrations of arsenate (table 6).

Dissolved arsenic concentrations are not known for some of the stratigraphic intervals with the highest solid-phase arsenic concentrations. For glacial deposits, the highest solid-phase arsenic concentrations were in fine-grained deposits and therefore not representative of aquifers in the study area. The horizon with the maximum solid-phase arsenic concentration - the unconsolidated bedrock zone — could have been included as part of a water-producing zone, but the solid-phase arsenic concentration was not known to be high at the time of monitor-well installation.

At each site, dissolved arsenic concentrations varied with depth, as did concentrations of constituents related to redox conditions: iron, sulfate, sulfide, and DOC (fig. 10).
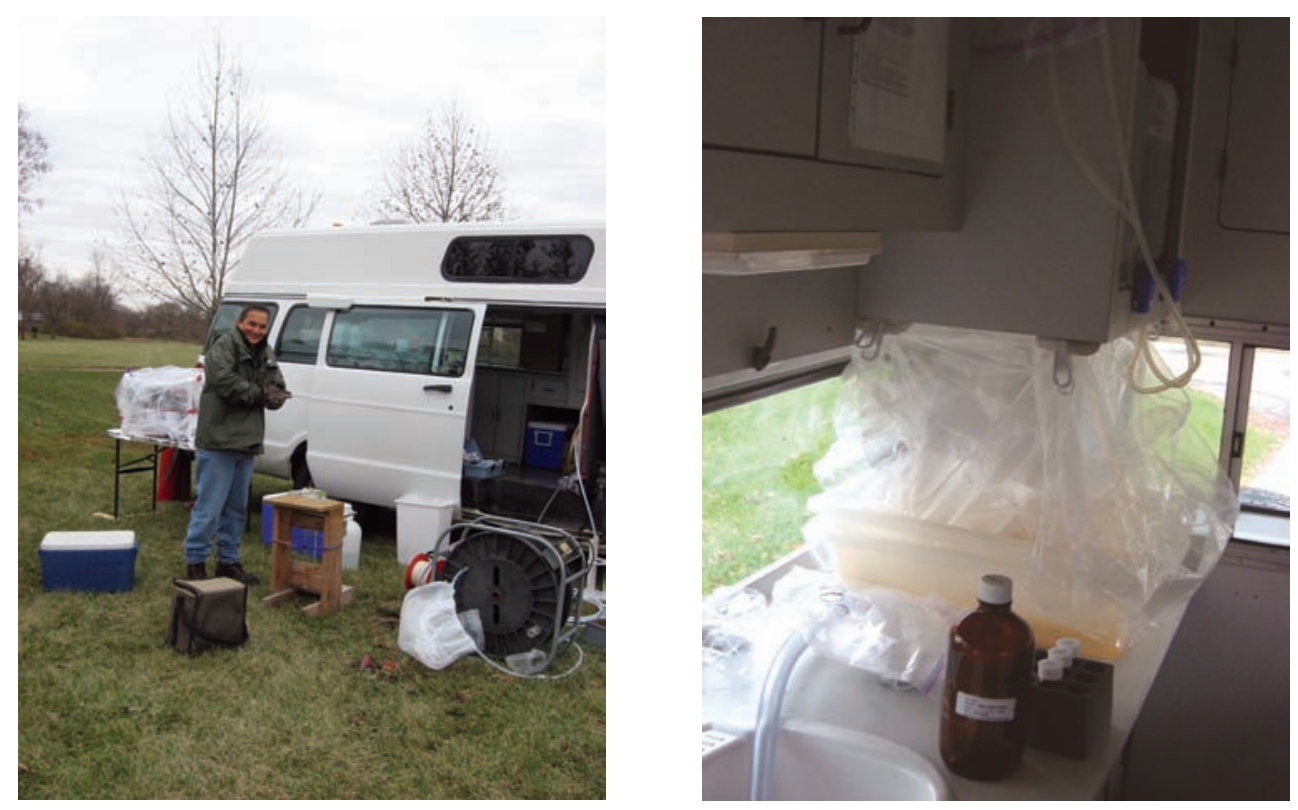

A mobile-laboratory setup similar to the one pictured here was used for water-quality sampling and sample processing at sites 1 and 2. Interior photo shows extensive sealing of equipment to prevent sample contamination. (Photos by Mary Ann Thomas, U.S. Geological Survey.) 
Table 6. Selected water-quality constituents and properties from six horizons.

[BLS, below land surface; fltrd, filtered; unfltrd, unfiltered; mg/L, milligrams per liter; $\mu \mathrm{g} / \mathrm{L}$, micrograms per liter; NTU, nephelometric turbidity units]

\begin{tabular}{lcccccc}
\hline Horizon & $\begin{array}{c}\text { Well } \\
\text { identifier }\end{array}$ & $\begin{array}{c}\text { Well } \\
\text { depth } \\
\text { (feet BLS) }\end{array}$ & $\begin{array}{c}\text { Turbidity } \\
\text { (NTU) }\end{array}$ & $\begin{array}{c}\text { Dissolved } \\
\text { oxygen } \\
\text { (mg/L) }\end{array}$ & pH & $\begin{array}{c}\text { Alkalinity, } \\
\text { fltrd, } \\
\text { (mg/L as } \\
\text { CaCO }_{3} \text { ) }\end{array}$ \\
\hline 1A & 395430084415400 & 35 & 150 & 0.7 & 7.2 & 403 \\
1B & 395429084415500 & 52 & 3.0 & .1 & 7.2 & 398 \\
1C & 395429084415600 & 88 & 2.5 & .1 & 7.4 & 359 \\
2A & 395236084403600 & 37 & 2.4 & .1 & 7.4 & 373 \\
2B & 395236084403601 & 80 & 2.7 & .1 & 7.2 & 375 \\
2C & 395237084403600 & 93 & 6.8 & .1 & 7.4 & 338 \\
\hline
\end{tabular}

\begin{tabular}{|c|c|c|c|c|c|c|c|c|}
\hline Horizon & $\begin{array}{c}\text { Chloride } \\
\text { (mg/L) }\end{array}$ & $\begin{array}{c}\text { Sulfate, } \\
\text { fltrd } \\
\text { (mg/L) }\end{array}$ & $\begin{array}{c}\text { Sulfide, } \\
\text { unfltrd } \\
\text { (mg/L) }\end{array}$ & $\begin{array}{c}\text { Ammonia, } \\
\text { fltrd } \\
(\mathrm{mg} / \mathrm{L} \text { as } \\
\mathrm{N} \text { ) }\end{array}$ & $\begin{array}{l}\text { Nitrate + } \\
\text { nitrite, } \\
\text { fltrd (mg/L } \\
\text { as } \mathrm{N} \text { ) }\end{array}$ & $\begin{array}{c}\text { Ortho- } \\
\text { phospho- } \\
\text { rus, } \\
\text { fltrd } \\
\text { (mg/L as P) } \\
\end{array}$ & $\begin{array}{c}\text { Organic } \\
\text { carbon, } \\
\text { fltrd } \\
(\mathrm{mg} / \mathrm{L})\end{array}$ & \\
\hline $1 \mathrm{~A}$ & 7.4 & 249 & 0.099 & .52 & $<0.06$ & $<0.006$ & 1.5 & \\
\hline $1 \mathrm{~B}$ & 4.5 & 164 & .015 & .74 & $<.06$ & .006 & 1.4 & \\
\hline $1 \mathrm{C}$ & 21 & 75 & .007 & .38 & .11 & $<.006$ & 1.1 & \\
\hline $2 \mathrm{~A}$ & 67 & 72 & .002 & .96 & $<.06$ & $<.006$ & 1.2 & \\
\hline 2B & 9.1 & 34 & .032 & 1.36 & $<.06$ & .014 & 2.6 & \\
\hline 2C & 3.7 & .1 & .016 & 2.17 & $<.06$ & .032 & 3.6 & \\
\hline Horizon & $\begin{array}{c}\text { Arsenate, } \\
\text { fltrd } \\
(\mu \mathrm{g} / \mathrm{L})\end{array}$ & $\begin{array}{c}\text { Arsenic, } \\
\text { fltrd } \\
(\mu \mathrm{g} / \mathrm{L})\end{array}$ & $\begin{array}{c}\text { Arsenite, } \\
\text { fltrd } \\
\text { ( } \mu \mathrm{g} / \mathrm{L})\end{array}$ & $\begin{array}{l}\text { Iron, } \\
\text { fltrd } \\
(\mu \mathrm{g} / \mathrm{L})\end{array}$ & $\begin{array}{c}\text { Man- } \\
\text { ganese, } \\
\text { fltrd } \\
(\mu \mathrm{g} / \mathrm{L})\end{array}$ & \multicolumn{2}{|c|}{$\begin{array}{c}\text { Redox } \\
\text { designation }\end{array}$} & $\begin{array}{c}\text { Mass ratio } \\
\text { of iron to } \\
\text { sulfide }\end{array}$ \\
\hline $1 \mathrm{~A}$ & 5.9 & 12.9 & 8.1 & 1,560 & 92.1 & \multicolumn{2}{|c|}{$\begin{array}{l}\mathrm{Fe} / \mathrm{SO}_{4} \text { reducing or } \\
\text { mixed }\end{array}$} & 16 \\
\hline 1B & 2.4 & 4.6 & 1.7 & 2,810 & 61.6 & \multicolumn{2}{|c|}{$\mathrm{Fe} / \mathrm{SO}_{4}$ reducing } & 187 \\
\hline $1 \mathrm{C}$ & 1.3 & 1.8 & $<1.0$ & 4,460 & 59.4 & \multicolumn{2}{|c|}{$\mathrm{Fe} / \mathrm{SO}_{4}$ reducing } & 637 \\
\hline $2 \mathrm{~A}$ & 3.2 & 6.1 & 2.8 & 2,450 & 24.6 & \multicolumn{2}{|c|}{$\mathrm{Fe} / \mathrm{SO}_{4}$ reducing } & 1,225 \\
\hline $2 \mathrm{~B}$ & $<1.2$ & .2 & $<1.0$ & 3,800 & 152 & \multicolumn{2}{|c|}{$\mathrm{Fe} / \mathrm{SO}_{4}$ reducing } & 119 \\
\hline $2 \mathrm{C}$ & 8.6 & 51.1 & 40.6 & 1,390 & 44.5 & \multicolumn{2}{|c|}{ Methanogenic } & 87 \\
\hline
\end{tabular}




\section{Site 1}

At site 1, dissolved arsenic concentrations decreased progressively with depth (fig. 10). In horizon $1 \mathrm{~A}$ (glacial deposits at 30-35 ft), the arsenic concentration was $13 \mu \mathrm{g} / \mathrm{L}$. In horizon 1B (glacial deposits at 47-52 ft), the arsenic concentration was $5 \mu \mathrm{g} / \mathrm{L}$. In horizon 1C (carbonate bedrock at 83-88 ft), the arsenic concentration was $2 \mu \mathrm{g} / \mathrm{L}$.

For the two deeper horizons-1B and 1C-the redox condition was estimated to be predominantly iron reducing, with sulfate reduction also indicated. For horizon $1 \mathrm{~A}$, the redox designation was similar, except that the DO concentration was just above the threshold indicative of oxygen reduction. Horizon $1 \mathrm{~A}$ was 10 to $15 \mathrm{ft}$ below the water table in a recharge area, so it is possible that (1) horizon 1A spans multiple redox zones, (2) pumping caused drawdown of oxygenated water through fractures in the overlying glacial till, or (3) a small amount of oxygen was introduced during the sampling process.

\section{Site 2}

At site 2, dissolved arsenic concentrations and redox conditions were more varied than at site 1 (fig. 10). In horizon 2A (glacial deposits at 32-37 ft), the arsenic concentration was $6 \mu \mathrm{g} / \mathrm{L}$, and in horizon 2B (glacial deposits at 75-80 ft), the arsenic concentration was $0.2 \mu \mathrm{g} / \mathrm{L}$. In both horizons, the predominant redox process was iron reduction, with sulfate reduction also indicated. However, sulfate reduction appears to be more prevalent in the deeper horizon (2B) because the water had a strong rotten-egg odor and the concentration of sulfide was high relative to iron. In horizon 2C (organic-rich glacial deposits at 90-93 ft), the dissolved arsenic concentration was $51 \mu \mathrm{g} / \mathrm{L}, 5$ times the MCL. The redox condition was methanogenic because the sulfate concentration was less than $0.5 \mathrm{mg} / \mathrm{L}$, the approximate threshold below which sulfate reduction is replaced by methanogenesis as the predominant redox process (McMahon and Chapelle, 2008).

At site 2, redox conditions appeared to be progressively more reducing with depth, which is consistent with the increase in DOC concentrations with depth (fig. 10). However, the relation between depth and dissolved arsenic was more erratic: arsenic concentrations showed large shifts, especially between horizons 2B and 2C, where dissolved arsenic increased from 0.2 to $51 \mu \mathrm{g} / \mathrm{L}$ over a depth of $15 \mathrm{ft}$ and a distance of $150 \mathrm{ft}$.
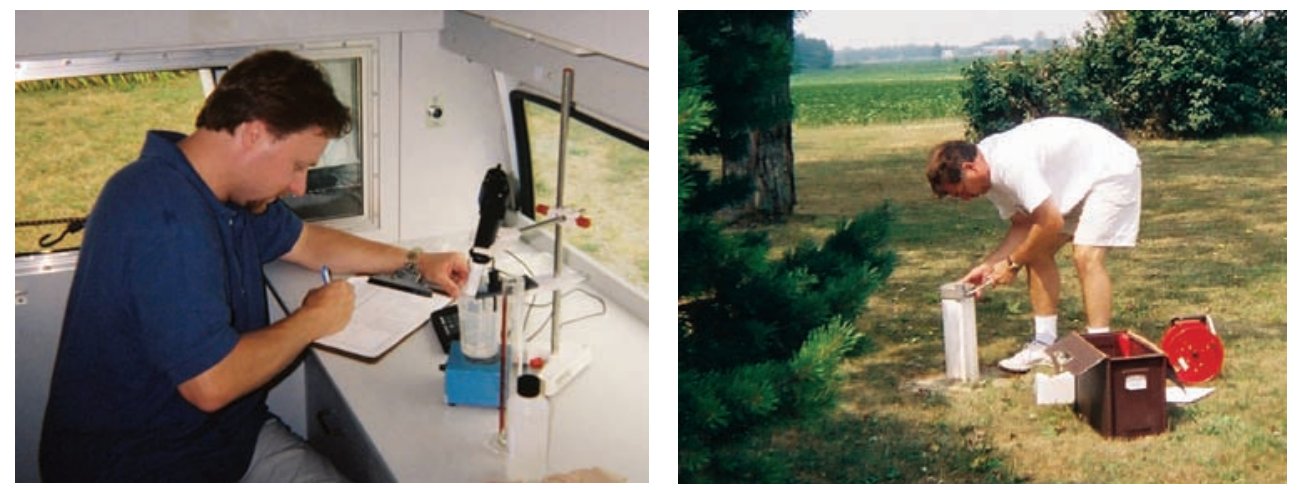

Coauthors Bruce Pletsch and Tom Schumann at work: Bruce (at left) titrates a water-quality subsample for alkalinity, while Tom (right) gathers information on a sampled well. (Photographs by the two coauthors.) 


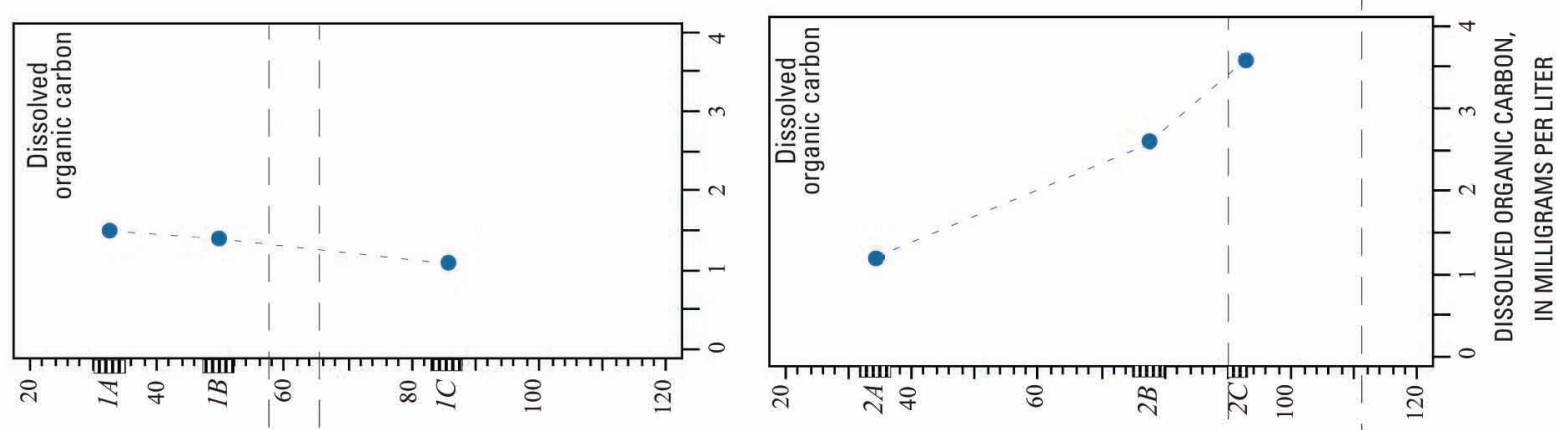




\section{Relation Between Arsenic in Ground Water and the Solid Phase}

In the study area, arsenic concentrations in the ground water are not simply a function of arsenic concentrations of the aquifer materials (fig. 11). There appears to be some relation between the two phases because the horizon with the highest concentration of solid-phase arsenic also had the highest dissolved arsenic (2C), and the horizon with the lowest solid-phase arsenic concentration had one of the lowest concentrations of dissolved arsenic (1C). However, for two pairs of horizons (1A and 1B; $2 \mathrm{~A}$ and $2 \mathrm{~B})$, arsenic concentrations in the ground water were inversely related to those of the solid phase.

In this section of the report, ground water and solidphase characteristics of each horizon are examined in light of hypotheses for arsenic mobilization. Simplified geochemical modeling was used to further assess the hypotheses. Two types of geochemical models were run with PHREEQC (Parkhurst and Appelo, 1999). Speciation modeling calculates the saturation state of ground water with respect to a particular set of minerals. Inverse mass-balance modeling identifies solid-water reactions that can account for changes in the water composition between two or more samples along a flow path. The geochemical modeling approach was simplified in that the focus was not directly on arsenic but on the two most common arsenic-bearing minerals: sulfides and iron oxides. The results of chemical equilibrium modeling are hypothetical because (1) the assumption of chemical equilibrium may not be met, (2) one of more of the presumed solid-phase reactants may not be present, or (3) the kinetics of reactions may not be favorable. In addition, the mineral stoichiometry for arsenic, as well as other trace elements, is often not known.

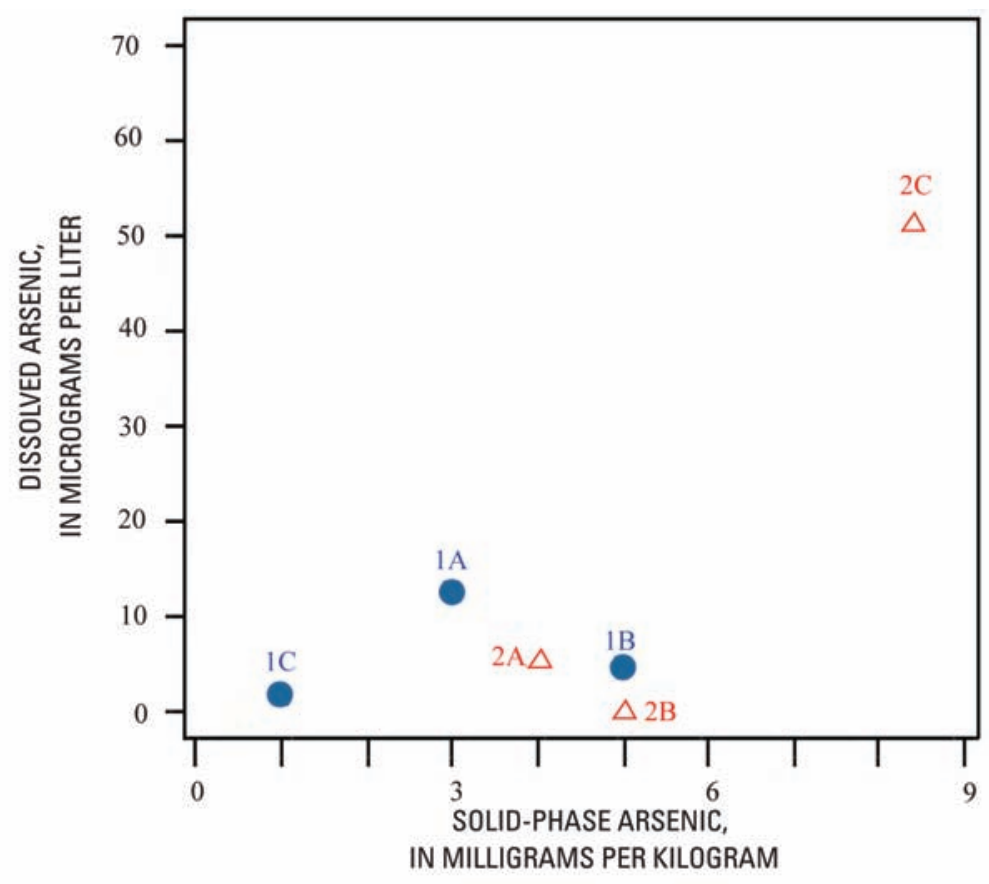

\begin{tabular}{|c|c|c|c|c|c|c|c|c|c|c|}
\hline \multirow{3}{*}{ Horizon } & \multirow{3}{*}{$\begin{array}{c}\text { Aquifer type, } \\
\text { open in terval, in ft }\end{array}$} & \multicolumn{4}{|c|}{ Solid phase, in mg/kg } & \multicolumn{5}{|c|}{ Ground water, in mg/L } \\
\hline & & \multirow{2}{*}{ Arsenic } & \multirow{2}{*}{ Iron } & \multirow{2}{*}{ Sulfur } & \multirow{2}{*}{$\begin{array}{c}\text { Organic } \\
\text { carbon }\end{array}$} & \multirow{2}{*}{ Arsenic } & \multirow{2}{*}{ Iron } & \multicolumn{2}{|c|}{ Sulfur } & \multirow{2}{*}{ DOC } \\
\hline & & & & & & & & Sulfate & Sulfide & \\
\hline $1 \mathrm{~A}$ & Glacial, 30-35 & 3 & 8,000 & 600 & 3,000 & .013 & 1.6 & 249 & .099 & 1.5 \\
\hline IB & Glacial, 47-52 & 5 & 11,600 & 1,900 & 5,000 & .005 & 2.8 & 164 & .015 & 1.4 \\
\hline IC & Carbon ate, $83-88$ & $<1$ & 1,500 & $<500$ & $<1,000$ & .002 & 4.5 & 75 & .007 & 1.1 \\
\hline $2 \mathrm{~A}$ & Glacial, 32-37 & 4 & 12,000 & 800 & 4,700 & .006 & 2.5 & 72 & .002 & 1.2 \\
\hline 2B & Glacial, 75-80 & 5 & 14,000 & 2,400 & 1,600 & .0002 & 3.8 & 34 & .032 & 2.6 \\
\hline $2 \mathrm{C}$ & Glacial, 90-93 & 8.5 & 22,000 & 1,000 & 5,000 & .051 & 1.4 & $<1$ & .016 & 3.6 \\
\hline
\end{tabular}

Figure 11. Relation between arsenic concentrations in the solid phase and ground water in northern Preble County, Ohio. (DOC, dissolved organic carbon.) 
For this study, inverse mass-balance models were run for pairs of samples from glacial deposits that appear to be hydraulically connected on the basis of water levels in monitor wells (table 3). The selection of the solid-phase reactants was guided by the mineralogical descriptions (Appendix 4). Solid-phase reactants were postulated to be dolomite, calcite, chalcedony (silica), potassium feldspar, pyrite, goethite (iron oxides), organic matter, and illite and kaolinite (clays). Although gypsum can be an important source of sulfate to ground water, it was not included as a solid-phase reactant because it was not identified in any of the thin sections or in the bedrock cores. Halite was not observed in the thin sections, but it was included as a reactant to account for dissolved chloride concentrations that were probably from anthropogenic sources at land surface. Exchange sites were added to allow cation exchange for calcium, magnesium, sodium, and potassium. Gas reactants were postulated to be oxygen and carbon dioxide.

\section{Glacial Deposits}

Horizons 1A and 1B are lenses or layers of sand and gravel within glacial till. A large fraction of the sand and gravel is composed of carbonate bedrock clasts, along with clasts of igneous and sedimentary rocks and grains of quartz and feldspar. In horizon $1 \mathrm{~A}$, at 30 to $35 \mathrm{ft}$, the dissolved arsenic concentration was $13 \mu \mathrm{g} / \mathrm{L}$, which exceeds the MCL. In horizon $1 \mathrm{~B}$, at 47 to $52 \mathrm{ft}$, the dissolved arsenic concentration decreased to $5 \mu \mathrm{g} / \mathrm{L}$. Over the same interval, solid-phase arsenic concentrations increased slightly, from $3 \mu \mathrm{g} / \mathrm{L}$ in horizon $1 \mathrm{~A}$ to $5 \mu \mathrm{g} / \mathrm{L}$ in horizon $1 \mathrm{~B}$. The redox conditions in both horizons were predominantly iron reducing, with sulfate reduction also indicated. In horizon $1 \mathrm{~A}$, which is $10 \mathrm{ft}$ below the water table, a small amount of dissolved oxygen was detected.

In the study area, the hypothesis is that arsenic is released from iron oxides under reducing conditions. As a broad generalization, ground water becomes more reducing with depth, so dissolved arsenic concentrations might be expected to increase with depth. However, between horizons $1 \mathrm{~A}$ and 1B, concentrations of dissolved arsenic decreased, and solid-phase concentrations increased slightly.

Similar relations among depth and concentrations of dissolved and solid phase arsenic were observed at site 2 . In horizon $2 \mathrm{~A}$, at 32 to $37 \mathrm{ft}$, the arsenic concentration was $6 \mu \mathrm{g} / \mathrm{L}$ in the ground water and $4 \mathrm{mg} / \mathrm{kg}$ the solid phase. In horizon $2 \mathrm{~B}$, at 75 to $80 \mathrm{ft}$, the arsenic concentration was $0.2 \mu \mathrm{g} / \mathrm{L}$ in the ground water and $5 \mathrm{mg} / \mathrm{kg}$ in the solid phase. In both horizons, the predominant redox process was iron reduction, with sulfate reduction also indicated. Sulfate reduction was more prevalent in horizon 2B than elsewhere. A similar relation between depth and dissolved arsenic concentrations was also noted for a larger area of southwestern Ohio (Thomas and others, 2005). Ten ground-water samples from similar glacial deposits-sand and gravel lenses within till-were analyzed for arsenic during 2002-3, and the samples showed a trend of decreased arsenic concentrations with depth.
One possible explanation for these observations is that a greater proportion of the arsenic in the shallower horizons is associated with iron oxides and is therefore mobile under reducing conditions, whereas in the deeper horizons, a greater proportion of the solid-phase arsenic is associated with pyrite and is therefore not mobile under reducing conditions (table 2). This idea is generally consistent with micrographs from horizons $1 \mathrm{~A}$ and $1 \mathrm{~B}$; arsenic-bearing pyrite was observed in both horizons, but in the shallower horizon, they were coated with arsenic-bearing iron oxides (fig. 5), and in the deeper horizon, the arsenic-bearing pyrite showed no evidence of weathering (fig. 6).

A second possible explanation is that the arsenic in the deeper horizons was removed from the ground water and sequestered in the solid phase as a result of pyrite precipitation. This is consistent with the observation that horizon 2B had the strongest evidence of active sulfate reduction and the lowest concentration of dissolved arsenic. In addition, a micrograph from horizon 2B showed arsenic associated with a second generation of pyrite that coats the older framboidal pyrite (fig. 8).

The results of geochemical modeling are generally consistent with these two ideas, although it is not possible to differentiate between them. Results of speciation modeling showed that horizons $1 \mathrm{~A}, 1 \mathrm{~B}, 2 \mathrm{~A}$, and $2 \mathrm{~B}$ were oversaturated with respect to pyrite. This indicates that pyrite could precipitate, but it should not dissolve. So, in these horizons, pyrite is likely to be a sink for dissolved arsenic rather than a source. (The results of speciation modeling were similar for the other two water-producing horizons, $1 \mathrm{C}$ and 2C.)

Inverse mass-balance modeling was used to identify possible solid-water reactions that could account for changes in water composition between horizons $1 \mathrm{~A}$ and $1 \mathrm{~B}$. The groundwater sample from horizon 1A was used as the initial water composition and the sample from horizon $1 \mathrm{~B}$ as the final water composition (Appendix 5A). Using the specified set of reactants, four models can account for the change in water composition, and each model includes the dissolution of iron oxides (and organic carbon) and the precipitation of pyrite. The same is true for mass-balance modeling between horizons 2A and 2B (Appendix 5B) and horizons 2B and 2C (Appendix 5C).

Horizon 2C consists of organic-rich glacial deposits at a depth of 90 to $93 \mathrm{ft}$. The solid-phase arsenic concentration was $8.5 \mathrm{mg} / \mathrm{kg}$. Although this is the highest solid-phase concentration among the six water-producing horizons, it is within the range of typical values for unconsolidated deposits (table 1). The dissolved arsenic concentration was $51 \mu \mathrm{g} / \mathrm{L}$, which is 5 times the MCL. The thin section of the aquifer material showed large fragments of cellular organic matter, which could account for the relatively high DOC concentration and the methanogenic redox designation of horizon 2C.

The large increase in dissolved arsenic concentrations between horizons 2B and 2C is not unusual; similar extreme variations in arsenic concentrations over relatively short distances and (or) depths have been observed elsewhere. For 
example, the Mahomet Aquifer system of central Illinois is a glacial valley-fill deposit overlain by a thick layer of glacial till. The ground water is reducing, and elevated arsenic concentrations are common. Kirk and others (2004) observed that arsenic concentrations were low in sulfate-reducing conditions and were high in methanogenic conditions. The authors concluded that, under sulfate-reducing conditions, sulfide precipitation removed arsenic from the ground water and sequestered it in the solid phase. On the other hand, under methanogenic conditions, sulfate reduction was not active, and sulfide precipitation did not remove arsenic from the ground water; so, arsenic accumulated in the ground water to high concentrations (Kirk and others, 2004).

There is also some evidence from the study area to support the idea that elevated arsenic concentrations in ground water can result from a shift from oxic to reducing conditions. Under oxic conditions, arsenic-bearing sulfide minerals dissolve and form arsenic-bearing iron oxides, which are stable under oxic conditions. However, if redox conditions become reducing - for example, in response to a rise in the water table-iron oxides can dissolve and release arsenic to the ground water. This idea is consistent with the observation that the highest arsenic concentrations in the solid phase were detected near the transition zone between the top of Silurian bedrock and the base of Wisconsinan glacial deposits. In addition, the micrograph from horizon 1A (fig. 5) shows a carbonate-rock fragment with arsenic-bearing pyrite that has been partially dissolved and coated with arsenic-bearing iron oxides. The iron oxides also show evidence of partial dissolution, which could be the result of the current redox state of that horizon.

Inverse mass-balance modeling was done using hypothetical rainwater as the initial water and the ground-water sample from horizon $1 \mathrm{~A}$ as the final water (Appendix 5D). Horizon $1 \mathrm{~A}$ is 10 to $15 \mathrm{ft}$ below the water table, so this simulation relates to reactions in the unsaturated zone and (or) just below the water table. Two inverse models were found for the specified set of reactants. Both models indicated that the dissolution of pyrite and the precipitation of iron oxides could account for the composition of ground water in horizon 1A. These modeling results are consistent with the conceptual model shown in figure 2: dissolution of pyrite and precipitation of iron oxides can occur in oxic ground water (presumably from land surface to just below the water table). Conversely, dissolution of iron oxides and precipitation of pyrite can occur in reducing ground water (presumably at about the depth of horizon $1 \mathrm{~A}$ and deeper).

\section{Carbonate Bedrock}

Horizon 1C was at a depth of 83 to $88 \mathrm{ft}$ in the Lockport Dolomite at site 1 . The dissolved arsenic concentration was $2 \mu \mathrm{g} / \mathrm{L}$, and the predominant redox process was iron reduction, with sulfate reduction also indicated. The solid-phase arsenic concentration was less than $1 \mathrm{mg} / \mathrm{kg}$, which is relatively low.
The solid phase also had low concentrations of iron, sulfur, and organic carbon (fig. 4). A thin section from horizon 1C shows iron-bearing dolomite with framboidal pyrite, but no arsenic was detected at the limits of the SEM. For horizon 1C, the low concentration of dissolved arsenic might be related to the low concentration of arsenic in the solid phase.

However, solid-phase arsenic concentrations in bedrock were not uniformly low; the unconsolidated bedrock zone at site 1 had a high outlier concentration of arsenic in addition to high concentrations of zinc, lead, nickel, and strontium. This was a 6-in. layer of dolomite clasts and clay at a depth of $77 \mathrm{ft}$, which is about $10 \mathrm{ft}$ below the top of bedrock. The zone was sandwiched in between competent bedrock, so it was interpreted as cavity fill. Mineralogical evidence suggested that the sediments had been altered by geothermal fluids. It is possible that this was a porous zone that served as a conduit for the migration of mineralized fluids through bedrock.

Goldhaber and others (2003) proposed that arsenicbearing sulfides were deposited in Paleozoic carbonates by large-scale migrations of hydrothermal fluids related to mountain-building events in the Ouachita and Appalachian Basins. The mineralized fluids were related to Mississippi Valley-type (MVT) ores. They migrated out of structural basins and towards arches through porous and laterally continuous bedrock formations, some of which now serve as important aquifers in the midcontinent (Goldhaber and others, 2003). Further study might be warranted to investigate the link between this hypothesis and observations from the study area. Mineral assemblages in some of the thin sections appear to be related to MVT mineralization. In addition, the geology and structural setting of the study area are appropriate: the Lockport Dolomite is part of an extensive carbonate formation that underlies the Illinois Basin and subcrops along the Cincinnati Arch in southwestern Ohio.

Further study might be warranted to determine whether similar mineralized zones are present elsewhere in the carbonate aquifer and whether ground water from these zones has elevated arsenic concentrations. If so, it might be possible to reduce the arsenic concentration of ground water produced from a well in carbonate bedrock by excluding discrete horizons from the open interval of the well. The concentration of arsenic in ground water from the unconsolidated bedrock zone is not known. However, a domestic well about $300 \mathrm{ft}$ east of site 1 was sampled as part of the previous investigation (Thomas and others, 2005). The well produced water from a 34-ft open interval in carbonate bedrock, and the arsenic concentration was $11 \mu \mathrm{g} / \mathrm{L}$, which exceeds the MCL. It is possible that the domestic well produced water from a thick interval of low-arsenic bedrock and a thin interval of high-arsenic bedrock (fig. 4). In contrast, the monitor well in horizon 1C (83-88 ft) had a 5 -ft well screen, so all of the water could have come from the interval of bedrock with low solid-phase arsenic concentrations. It is not known whether a higher rate of pumping, similar to that for a domestic well, would induce flow of water from the high-arsenic zone at $77 \mathrm{ft}$ into the well screen at 83 to $88 \mathrm{ft}$. 
A widespread permeable zone at or near the top of the Lockport Dolomite was identified as a possible important source of water in west-central Ohio (Strobel and Bugliosi, 1991). It is not known whether that widespread permeable zone is related to the arsenic-rich unconsolidated sediment near the top of the Lockport Dolomite at site 1.

\section{Summary and Conclusions}

In southwestern Ohio, elevated arsenic concentrations have been detected at a range of depths within the groundwater system. In 2002, the U.S. Geological Survey (USGS), in cooperation with the Miami Conservancy District, began an investigation to determine which parts of the aquifer system are most (and least) likely to produce water with elevated arsenic concentrations. During 2002 and 2003, the focus of the study was on water-quality data from domestic wells. A followup investigation began in 2004 to compare arsenic in ground water to characteristics of the solid-phase aquifer materials. Analysis of the solid phase was done by scientists from USGS Geologic Discipline and the Ohio Department of Natural Resources, Division of Geological Survey.

The study was in northern Preble County, Ohio. In this area, Pleistocene glacial deposits overlie Silurian carbonate bedrock, both of which are used as a source of water to domestic and public-supply wells. Two sites were chosen for study and, at each site, ground-water and solid-phase data were collected from three horizons. The solid phase was described in terms of the stratigraphy, bulk elemental composition of 70 samples, and microscopic analysis of thin sections. The ground water was characterized by analysis of samples from six water-producing horizons. Simplified geochemical modeling was used to investigate possible interactions between the ground water and the aquifer materials. Solid-phase arsenic concentrations were generally within normal ranges for similar geologic materials. At both study sites, the highest solid-phase arsenic concentrations were from a roughly similar stratigraphic position, a transition zone that extends from just above the Wisconsinan/Illinoian contact to just below the Pleistocene/Silurian contact.

Arsenic concentrations greater than the USEPA Maximum Contaminant Level (MCL) of $10 \mu \mathrm{g} / \mathrm{L}$ were detected in two of the six water-producing horizons. One was the shallowest horizon in glacial deposits at site 1 , which had an arsenic concentration of $13 \mu \mathrm{g} / \mathrm{L}$. The second was the deepest horizon in glacial deposits at site 2, which had a dissolved arsenic concentration of $51 \mu \mathrm{g} / \mathrm{L}$, which is 5 times the MCL. The concentrations of arsenic in the ground water were not directly related to concentrations in the solid phase.

Observations from the study area are generally consistent with the concept that arsenic in the ground water was released from iron oxides under reducing conditions, either by dissolution or desorption. Iron oxides were observed in thin sections of all six water-producing horizons, and the redox conditions were predominantly iron reducing, which is conducive to reductive dissolution or desorption from iron oxides. Sulfide minerals were also detected in each horizon, but sulfides are not soluble under reducing conditions and so are not the likely source of the dissolved arsenic. Results of speciation modeling indicated that the ground water in all horizons was oversaturated with respect to pyrite, so pyrite could precipitate but should not dissolve. Results of simplified mass-balance modeling indicated that the observed changes in water chemistry between pairs of horizons in glacial deposits are consistent with dissolution of iron oxides and organic carbon, and precipitation of pyrite.

Observations from the study area are also generally consistent with the concept that the release of arsenic can be related to a shift from oxic to reducing conditions. The highest concentrations of solid-phase arsenic were detected in a broad transition zone that extends from just above the Wisconsin/ Illinoian contact to just below the Pleistocene/Silurian contact. This is a zone where arsenic-bearing pyrite could have been transformed to arsenic-bearing iron oxides during a decline of sea level. A subsequent rise in sea level could presumably create reducing conditions conducive to release of arsenic from iron oxides. A thin section from horizon 1A showed evidence of pyrite dissolution and iron oxide formation, which would have required oxic conditions, and dissolution of the iron oxides, which would have required reducing conditions. Horizon 1A was about $10 \mathrm{ft}$ below the water table, presumably near the boundary between oxic and reducing conditions.

In addition, observations from the study area are generally consistent with the idea that dissolved arsenic can be removed from the ground water by precipitation of sulfide minerals under sulfate-reducing conditions; however, once sulfate is depleted, arsenic can accumulate in the ground water. At site 2, dissolved organic carbon concentrations increased and redox conditions became more reducing with depth, but arsenic concentrations showed erratic shifts with depth. The lowest arsenic concentration was in horizon $2 \mathrm{~B}$, where sulfate reduction was most prevalent, and the highest arsenic concentration was in horizon 2C-only about $15 \mathrm{ft}$ deeper-where the redox was estimated to be methanogenic. Presumably, when sulfate reduction is not active, arsenic is not sequestered in the solid phase, so it can accumulate in the ground water.

Solid-phase arsenic concentrations in carbonate bedrock were generally lower than in glacial deposits. However, there was one notable exception; a solid-phase arsenic concentration of $42 \mathrm{mg} / \mathrm{kg}$ was detected in a thin horizon that showed evidence of alteration by geothermal fluids. Further study might be warranted to determine (1) whether similar mineralized zones are the source of elevated arsenic in the carbonate aquifer, and (2) whether excluding such a zone from the open interval of a well could decrease the arsenic concentration of produced water. 


\section{References Cited}

Benbrahim-Talla, Lamia, and Waalkes, M.P., 2007, Inorganic arsenic and human prostate cancer: Environmental Health Perspectives, accessed February 12, 2008, at http://dx.doi. org/doi:10.1289/ehp.10423

Bendula, Rich, and Khourey, Chris, 1998, Arsenic in bedrock wells: Ohio Environmental Protection Agency Division of Drinking and Ground Waters, Drinking and Ground Water News, v. 4, issue 1.

Blackman, M.J., 1970, A detailed study of the Pleistocene history of a portion of Preble County, Ohio: Oxford, Ohio, Miami University, Master's Thesis, 160 leaves.

Botoman, George, and Stieglitz, R.D., 1978, The occurrence of sulfide and associated minerals in Ohio: Ohio Division of Geological Survey Report of Investigations 104, 11 p.

Brenton, R.W., and Arnett, T.L., 1993, Methods of analysis by the U.S. Geological Survey National Water Quality Laboratory-Determination of dissolved organic carbon by UVpromoted persulfate oxidation and infrared spectrometry: U.S. Geological Survey Open-File Report 92-480, 12 p.

Breit, G.N.; Whitney, J.; Foster, A.L.; Welch, A.H.; Yount, J.; Sanzolone, R.; Islam, Md. K.; Islam, Md. S.; Islam, Md. M.; Sutton, S.; and Newville, M., 2001, Preliminary evaluation of arsenic cycling in the sediments of Bangladesh, in Proceedings of the 2001 U.S. Geological Survey Workshop on Arsenic in the Environment, Denver, Colo., Feb. 21-22, 2001, accessed July 2001 at http://wwwbrr.cr.usgs.gov Arsenic/finalabstracts.htm

Briggs, P.H., and Meier, A.L., 2002, The determination of forty-two elements in geologic materials by inductively coupled plasma-mass spectrometry, in Taggart, J.E., Jr., ed., Analytical methods for chemical analysis of geologic and other materials, U.S. Geological Survey: U.S. Geological Survey Open-File Report 02-223, chap. I, p. I-1 through I-14.

Chapelle, F.H.; Bradley, P.M.; Lovely, D.R.; O’Neill, Kathleen; and Landmeyer, J.E., 2002, Rapid evolution of redox processes in a petroleum hydrocarbon-contaminated aquifer: Ground Water, v. 40, no. 4, p. 353-360.

Chapelle, F.H., Bradley, P.M., Thomas, M.A., and McMahon, P.B., in press, Distinguishing iron-reducing from sulfatereducing conditions: Ground Water.

Chen, Yu; Sanetella, R.M.; Kibriya, M.G.; Wang, Qiao; Kappil, Maya; Verret, W.J.; Graziano, J.H.; and Ahsan, Habibul, 2007, Association between arsenic exposure from drinking water and plasma levels of soluble cell adhesion molecules: Environmental Health Perspectives, accessed February 12, 2008, at http://dx.doi.org/doi:10.1289/ehp.10277
Davey, J.C.; Nomikos, A.P.; Wungjiranirun, Manida; Sherman, J.R.; Ingram, Liam; Batki, Cavus; Lariviere, J.P.; and Hamilton, J.W., 2007, Arsenic as an endocrine disruptorArsenic disrupts retinoic acid receptor- and thyroid hormone receptor-mediated gene regulation and thyroid hormonemediated amphibian tail metamorphosis: Environmental Health Perspectives, accessed February 12, 2008, at http://dx.doi.org/doi:10.1289/ehp.10131

Dumouchelle, D.H., 1998, Selected ground-water quality data of the Lockport Dolomite in Darke, Miami, Montgomery, and Preble Counties, Ohio: U.S. Geological Survey Open File Report 98-655, 13 p.

Eberts, S.M., and George, L.L., 2000, Regional ground-water flow and geochemistry in the Midwestern Basins and Arches aquifer system in parts of Indiana, Ohio, Michigan, and Illinois: U.S. Geological Survey Professional Paper 1423-C, 103 p.

Fenneman, N.M., and Johnson, D.W., 1946, Physical divisions of the United States: U.S. Geological Survey, scale $1: 7,000,000$.

Fishman, M.J., ed., 1993, Methods of analysis by the U.S. Geological Survey National Water Quality LaboratoryDetermination of inorganic and organic constituents in water and fluvial sediments: U.S. Geological Survey OpenFile Report 93-125, 217 p.

Garbarino, J.R., Bednar, A.J., and Burkhardt, M.R., 2002, Methods of analysis by the U.S. Geological Survey National Water-Quality Laboratory-Arsenic speciation in naturalwater samples using laboratory and field methods: U.S. Geological Survey Water-Resources Investigations Report 02-4144, 40 p.

Garbarino, J.R., 1999, Methods of analysis by the U.S. Geological Survey National Water-Quality LaboratoryDetermination of dissolved arsenic, boron, lithium, selenium, strontium, thallium, and vanadiam using inductively coupled plasma-mass spectrometry: U.S. Geological Survey Open-File Report 99-093, 31 p.

Gerrard, T.A., 1959, A petrographic study of the Dayton Formation, (Niagaran Series) Harrison and Twin Townships, Preble County, Ohio: Oxford, Ohio, Miami University, Master's Thesis, $77 \mathrm{p}$.

Goldhaber, M.B., Lee, R.C., Hatch, J.R., Pashin, J.C., and Treworgy, J., 2003, Role of large scale fluid-flow in subsurface arsenic enrichment, in Welch, A.H., and Stollenwerk, K.G., eds., Arsenic inground water-Occurrence and geochemistry: Boston, Kluwer Academic Publishers, chap. 5, p. 127-164.

Kelly, W.R., Holm, T.R., Wilson, S.D., and Roadcap, G.S., 2005, Arsenic in glacial aquifers-Sources and geochemical controls: Ground Water, v. 43, no. 4, p. 500-510. 
Kirk, M.F.; Holm, T.R.; Park, Jungho; Jin, Qusheng; Sanford, R.A.; Fouke, B.W.; and Bethke, C.M., 2004, Bacterial sulfate reduction limits natural arsenic concentration in groundwater: Geology, v. 32, no. 11, p. 953-956.

Lin, Wei; Wang, S.-L.; Wu, H.-J.; Chang, K.-H.; Yeh, Peter; Chen, C.-J.; and Guo, H.-R., 2008, Associations between arsenic in drinking water and pterygium in southwestern Taiwan: Environmental Health Perspectives, accessed April 16, 2008, at http://dx.doi.org/doi:10.1289/ehp.11111

Matisoff, Gerald; Khourey, C.J.; Hall, J.F.; Varnes, A.W.; and Strain, W.H., 1982, The nature and source of arsenic in northeastern Ohio ground water: Ground Water, v. 20, no. 4, p. 446-456.

McMahon, P.B., and Chapelle, F.H., 2008, Redox processes and water quality of selected principal aquifer systems: Ground Water, v. 46, no. 2, p. 259-271.

Miami Conservancy District, 2001, State of the aquifer, Lower Great Miami Sub-basin-January 2001: Dayton, Ohio, 45 p.

Miami Conservancy District, 2004, Water quality assessment in the Lower Great Miami River watershed2004: Accessed November 10, 2007, at http://www. miamiconservancy.org/resources/documents/FinalReportLGMAssessment.pd

Miami Conservancy District, 2005, Water quality assessment in the Stillwater River watershed-2005: Acessed November 10, 2007, at http://www.miamiconservancy.org resources/documents/Stillwaterassessmentcombined_000. pd

National Research Council, 1999, Arsenic in drinking water: Washington, D.C., National Academy Press, 310 p.

National Research Council, 2001, Arsenic in drinking water: 2001 Update; Washington, D.C., National Academy Press, 225 p.

Ohio Department of Natural Resources, Division of Geological Survey, 2004, Shaded bedrock topography map of Ohio (digital coverage): BG-3, version 1.1.

Ohio Environmental Protection Agency, 2000, 2000 305(B) Report, Ohio's ground water quality: Division of Drinking and Ground Waters, p. 33-37.

Ohio Environmental Protection Agency, 2002, 2002 305(B) Report, Ohio's ground water quality: Division of Drinking and Ground Waters, p. 67-75.

Parkhurst, D.L., and Appelo, C.A.J., 1999, User's guide to PHREEQC (version 2)—A computer program for speciation, batch-reaction, one-dimensional transport, and inverse geochemical calculations: U.S. Geological Survey WaterResources Investigations Report 99-4259, 312 p.
Paschke, S.S., ed., 2007, Hydrogeologic settings and groundwater flow simulations for regional studies of the transport of anthropogenic and natural contaminants to public-supply wells_-Studies begun in 2001: U.S. Geological Survey Professional Paper 1737-A, accessed April 20, 2008, at http:// pubs.er.usgs.gov/usgspubs/pp/pp1737A

Rowe, G.L., Jr.; Reutter, D.C.; Runkle, D.L.; Hambrook, J.A.; Janosy, S.D.; and Hwang, L.H., 2004, Water quality in the Great and Little Miami River Basins, Ohio and Indiana, 1999-2001: U.S. Geological Survey Circular 1229, 40 p.

Savage, K.S., Tingle, T.N., O’Day, P.A., Waychunas, G.A., and Bird, D.K., 2000. Arsenic speciation in pyrite and secondary weathering phases, Mother Lode Gold District, Tuolumne County, California: Applied Geochemistry, v. 15, p. 1219-1244.

Shindel, H.L., Mangus, J.P., and Frum, S.R., 2005, Water resources data, Ohio, water year 2004: U.S. Geological Survey Water-Data Report OH-04-2, accessed January 10, 2006, at http://pubs.usgs.gov/wdr/2004/wdr-oh-04/WDROH-04-2.pdf

Slattery, M., Kenah, C., Slattery, L., and Musser, K., 2000, Occurrence and release of groundwater arsenic in public water supply wells in Ohio [abs], in 45th Annual Midwest Ground Water Conference, Columbus, Ohio: p. 63.

Slucher, E.R., Swinford, E.M., Larsen, G.E., Schumacher, G.A., Shrake, D.L., Rice, C.L., Caudill, M.R., and Rea, R.G., with cartography by D.M. Powers, 2006, Bedrock geologic map of Ohio: Ohio Department of Natural Resources, Division of Geological Survey Map BG-1, ver. 6, scale 1:500,000.

Smedley, P.L., and Kinniburgh, D.G., 2002, A review of the source, behaviour, and distribution of arsenic in natural waters: Applied Geochemistry, v. 17, no. 5, p. 517-568.

Stout, Wilber, 1941, Dolomites and limestones of Western Ohio: Geological Survey of Ohio, Fourth Series, Bulletin 42, 468 p.

Strobel, M.L., and Bugliosi, E.F., 1991, Areal extent, hydrogeologic characteristics, and possible origins of the carbonate rock Newburg zone (Middle-Upper Silurian) in Ohio: Ohio Journal of Science, v. 91, no. 5, p. 209-215.

Thomas, M.A., 2003, Arsenic in Midwestern glacial deposits-Occurrence and relation to selected hydrogeologic and geochemical factors: U.S. Geological Survey WaterResources Investigations Report 03-4228, 36 p.

Thomas, M.A., Schumann, T.L., and Pletsch, B.A., 2005, Arsenic in ground water in selected parts of southwestern Ohio, 2002-03: U.S. Geological Survey Scientific Investigations Report 2005-5138, 30 p. 
Thomas, M.A., 2007, The association of arsenic with redox conditions, depth, and ground-water age in the glacial aquifer system of the Northern United States: U.S. Geological Survey Scientific Investigations Report 2007-5036, 26 p.

U.S. Environmental Protection Agency, 2006, Arsenic rule: Accessed January 23, 2007, at http://www.epa.gov safewater/arsenic/regulations.htm

U.S. Geological Survey, variously dated, National field manual for the collection of water-quality data: U.S. Geological Survey Techniques of Water-Resources Investigations, book 9, chaps. A1-A9, accessed January 23, 2007, at http://pubs. er.usgs.gov/usgspubs/twri/twri09

Welch, A.H., Westjohn, D.B., Helsel, D.R., and Wanty, R.B., 2000, Arsenic in ground water of the United States-

Occurrence and geochemistry: Ground Water, v. 38, no. 4, p. 589-604. 


\section{Appendixes}




\section{Appendix 1. Core log descriptions compiled by the Ohio Department of Natural Resources, Division of Geological Survey-A. Site 1, glacial deposits.}

\section{STATE OF OHIO \\ DEPARTMENT OF NATURAL RESOURCES DIVISION OF GEOLOGICAL SURVEY}

CORE LOG

File Number: 3571

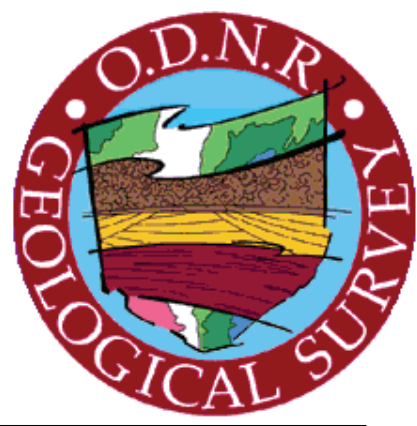

FILE NO.: 3571

COUNTY: Preble

TOWNSHIP: Monroe

SECTION: T9N, R2E, Sec. 6

QUADRANGLE: New Madison 7.5-min.

FIELD NO.: MCD 3, Hole 2

MEASURED BY: R. R. Pavey

DATE: July 29, 2004

STATE PLANE SOUTH 1983 COORDINATES: X: 1,351,779 Y: 702,438

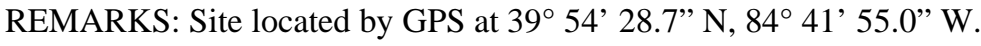

4121 Eldorado-Whitewater Rd., Eldorado, OH 45321. Hole was drilled for the U.S. Geological Survey, Water Resources Division, Columbus, OH. Geology was supervised by Mary Ann Thomas of the USGS for arsenic in groundwater investigation. Drilled by USGS-WRD Wisconsin District with a CME-75, 4" diameter continuous sampler to $43 \mathrm{ft}$., switched to 3" diameter split-spoon sampler.

\begin{tabular}{|r|c|c|c|l||}
\hline $\begin{array}{c}\text { Top of } \\
\text { interval (in } \\
\text { feet) }\end{array}$ & $\begin{array}{c}\text { Bottom of } \\
\text { interval (in } \\
\text { feet) }\end{array}$ & $\begin{array}{c}\text { Interval } \\
\text { thickness } \\
\text { (in feet) }\end{array}$ & $\begin{array}{c}\text { Cumulative } \\
\text { thickness (in } \\
\text { feet) }\end{array}$ & \multicolumn{1}{|c||}{ Description } \\
\hline 0 & .3 & .3 & .3 & $\begin{array}{l}\text { Mostly silt, some fine sand, dark brown, moist, turf } \\
\text { roots, non-calcareous. }\end{array}$ \\
\hline .3 & 2.0 & 1.7 & 2.0 & $\begin{array}{l}\text { Silty sandy till, common pebbles, mottled medium to } \\
\text { light brown, calcareous at 1.0 ft., secondary carbonate } \\
\text { mottling. Very hard and dry. 1.3 ft. recovered. }\end{array}$ \\
\hline 2.0 & 7.5 & 5.5 & 7.5 & $\begin{array}{l}\text { Silty sandy till, medium to light brown, mottling } \\
\text { decreases with depth, very calcareous, common } \\
\text { horizontal partings and vertical fractures lined with } \\
\text { secondary carbonate, dry and hard. Very broken from } \\
\text { 5.0 to 6.3 ft. Total of 6.8 ft. recovered. }\end{array}$ \\
\hline 7.5 & 11.3 & 3.8 & 11.3 & $\begin{array}{l}\text { Silty sandy till, medium brown, some orange-brown } \\
\text { blobs, massive, calcareous, no obvious secondary } \\
\text { carbonate, pebbles up to 2.5”. }\end{array}$ \\
\hline 11.3 & 16.0 & 4.7 & 16.0 & $\begin{array}{l}\text { Silty sandy till, medium gray, some brownish-gray } \\
\text { spots, massive, calcareous, slightly moist, hard. 4” } \\
\text { cobble at base. }\end{array}$ \\
\hline 16.0 & 27.2 & 11.2 & 27.2 & $\begin{array}{l}\text { Silty sandy till, medium gray, pebbly, massive, } \\
\text { calcareous, slightly moist, hard. }\end{array}$ \\
\hline 27.2 & 27.7 & .5 & 27.7 & $\begin{array}{l}\text { Silty fine sand, medium to light gray, calcareous, } \\
\text { moist. }\end{array}$ \\
\hline
\end{tabular}




\section{Appendix 1A. Site 1, glacial deposits.-Continued}

\begin{tabular}{|c|c|c|c|c|}
\hline 28.2 & 28.8 & (26 & 28.8 & $\begin{array}{l}\text { Silty sandy till, grayish-brown, pebbly, massive, } \\
\text { calcareous, slightly moist, hard. }\end{array}$ \\
\hline 28.8 & 29.1 & .3 & 29.1 & Sandy silty gravel, grayish-brown, calcareous, moist. \\
\hline 29.1 & 31.7 & 1.6 & 31.7 & $\begin{array}{l}\text { Silty sandy till, grayish-brown, pebbly, massive, } \\
\text { calcareous, slightly moist, hard. }\end{array}$ \\
\hline 31.7 & 33.7 & 2.0 & 33.7 & $\begin{array}{l}\text { Medium sand to 1" pebbles, gray, very poorly sorted, } \\
\text { subrounded to angular, calcareous. }\end{array}$ \\
\hline 33.7 & 34.0 & .3 & 34.0 & $\begin{array}{l}\text { Fragments of silty sandy till, dark grayish-brown, } \\
\text { calcareous, with sandy wash from above interval. }\end{array}$ \\
\hline 34.0 & 35.0 & 1.0 & 35.0 & No core recovery. \\
\hline 35.0 & 38.5 & 3.5 & 38.5 & $\begin{array}{l}\text { Silty sandy till, brownish-gray, massive, calcareous, } \\
\text { hard. }\end{array}$ \\
\hline 38.5 & 39.2 & .7 & 39.2 & $\begin{array}{l}\text { Silt, brownish-gray, massive, calcareous, a few small } \\
\text { pebbles, soft. }\end{array}$ \\
\hline 39.2 & 39.5 & .3 & 39.5 & $\begin{array}{l}\text { Silty sandy till, brownish-gray, massive, calcareous, } \\
\text { hard. }\end{array}$ \\
\hline 39.5 & 40.0 & .5 & 40.0 & $\begin{array}{l}\text { Fragments of silty sandy till, brownish-gray, } \\
\text { calcareous, hard, and loose pebbles, appears to be } \\
\text { washed during drilling. }\end{array}$ \\
\hline 40.0 & 42.0 & 2.0 & 42.0 & $\begin{array}{l}\text { Silty sandy till, brownish-gray, changing downward } \\
\text { to grayish-brown, massive, calcareous, hard. }\end{array}$ \\
\hline 42.0 & 43.0 & 1.0 & 43.0 & $\begin{array}{l}\text { Fragments of silty sandy till, light to medium brown, } \\
\text { dry, hard. }\end{array}$ \\
\hline 43.0 & 44.0 & 1.0 & 44.0 & $\begin{array}{l}\text { Begin split-spoon samples. Silty sandy till, brownish- } \\
\text { gray, massive, calcareous, hard. }\end{array}$ \\
\hline 44.0 & 47.0 & 3.0 & 47.0 & No core recovery. \\
\hline 47.0 & 49.0 & 2.0 & 49.0 & $\begin{array}{l}\text { Medium to fine sand with some silt, coarsening } \\
\text { downward to medium to coarse sand with some } \\
\text { pebbles up to .25”, gray, calcareous, settled wet in } \\
\text { box. }\end{array}$ \\
\hline 49.0 & 52.0 & 3.0 & 52.0 & No core recovery. \\
\hline 52.0 & 52.5 & .5 & 52.5 & $\begin{array}{l}\text { Silt to medium sand, brownish gray, poorly sorted, } \\
\text { calcareous, settled wet in box. }\end{array}$ \\
\hline 52.5 & 53.8 & 1.3 & 53.8 & $\begin{array}{l}\text { Silty sandy till, brownish-gray, massive, calcareous, } \\
\text { hard. }\end{array}$ \\
\hline 53.8 & 57.0 & 3.2 & 57.0 & No core recovery. \\
\hline 57.0 & 57.5 & .5 & 57.5 & Silty sandy till, brownish-gray, calcareous, very hard. \\
\hline 57.5 & 59.0 & 1.5 & 59.0 & $\begin{array}{l}\text { Clayey silt till, yellowish brown to orange-brown, } \\
\text { leached, not as hard as above. Some medium gray } \\
\text { reduction mottles. Probable paleosol. }\end{array}$ \\
\hline 59.0 & 62.0 & 3.0 & 62.0 & No core recovery. \\
\hline 62.0 & 63.3 & 1.3 & 63.3 & $\begin{array}{l}\text { Silty sandy till with some clay, mottled medium } \\
\text { brown to medium gray, becomes grayer with depth, } \\
\text { calcareous, hard. }\end{array}$ \\
\hline 63.3 & 64.8 & 1.5 & 64.8 & No core recovery. \\
\hline 64.8 & 65.0 & .2 & 65.0 & $\begin{array}{l}\text { Fragments of silty sandy till with some clay, medium } \\
\text { gray, calcareous, very hard. }\end{array}$ \\
\hline 65.0 & & & & End of hole. \\
\hline
\end{tabular}




\title{
Appendix 1B. Site 1, bedrock.
}

\author{
STATE OF OHIO \\ DEPARTMENT OF NATURAL RESOURCES \\ DIVISION OF GEOLOGICAL SURVEY \\ CORE LOG \\ File Number: 3570
}

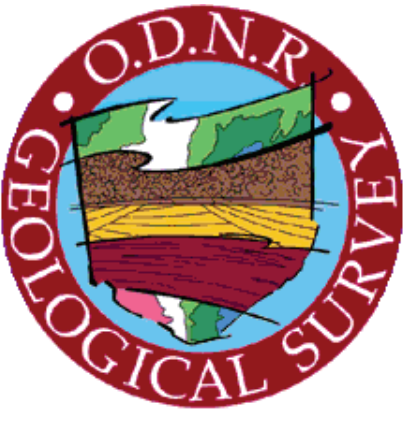

FILE NO.: 3570

COUNTY: Preble

TOWNSHIP: Monroe

SECTION: T9N, R2E, Sec. 6

QUADRANGLE: New Madison 7.5-min.

FIELD NO.: MCD3, Hole 1

MEASURED BY: E.M. Swinford

DATE: July 26, 2004

SURFACE ELEVATION: 1150 FEET S.L.

TOTAL DEPTH: 177.0 FEET

STATE PLANE SOUTH 1983 COORDINATES: X: 1,351,732 Y: 702,441

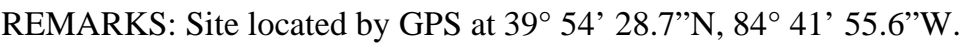

4121 Whitewater-Eldorado Road, Eldorado, OH 45321. Hole was drilled for the U.S. Geological

Survey, Water Resources Division, Columbus, OH. Geology was supervised by Mary Ann

Thomas of the USGS for arsenic in groundwater investigation. Bedrock units are the Lockport

Dolomite and the Laurel Dolomite.

\begin{tabular}{|c|c|c|c|c|}
\hline $\begin{array}{l}\text { Top of } \\
\text { interval (in } \\
\text { feet) }\end{array}$ & $\begin{array}{l}\text { Bottom of } \\
\text { interval (in } \\
\text { feet) }\end{array}$ & $\begin{array}{l}\text { Interval } \\
\text { thickness } \\
\text { (in feet) }\end{array}$ & $\begin{array}{l}\text { Cumulative } \\
\text { thickness (in } \\
\text { feet) }\end{array}$ & Description \\
\hline 0 & 73.0 & 73 & 73 & Glacial drift - not sampled \\
\hline 73.0 & 73.3 & 0.3 & 0.3 & $\begin{array}{l}\text { Dolomite, light gray (5Y 7/1), medium to fine } \\
\text { crystalline, slightly argillaceous to clean, well- } \\
\text { developed moldic porosity and abundant } \\
\text { petroliferous staining, black (5Y2 5/1) to live } \\
\text { petroleum tar oozing for rock. }\end{array}$ \\
\hline 73.3 & 76.7 & 3.4 & 3.7 & $\begin{array}{l}\text { Dolomite, light gray (5Y 7/1) to pale yellow (5Y } \\
\text { 8/2), fine to coarse crystalline, sucrosic, generally } \\
\text { clean, highly dolomitized fossil remnants, friable in } \\
\text { part, massive bedded with scattered layers of well- } \\
\text { developed porosity and medium crystalline } \\
\text { dolomite within by layers of lower porosity and } \\
\text { finer crystalline dolomite. }\end{array}$ \\
\hline 76.7 & 77.3 & 0.6 & 4.3 & $\begin{array}{l}\text { Clay and dolomite, soft, very friable, pebble-sized } \\
\text { clasts of clay, dark olive gray (5Y } 3 / 2) \text {, soft to } \\
\text { poorly indurated and particles of sucrosic dolomite. } \\
\text { Possible fracture fill or inwashed paleosol(?). }\end{array}$ \\
\hline 77.3 & 94.7 & 17.4 & 21.7 & $\begin{array}{l}\text { Dolomite, pale yellow (5Y 8/2) to light gray (5Y } \\
\text { 7/1), fine to coarse crystalline, clean to slightly } \\
\text { argillaceous, mottled, moldic porosity with some } \\
\text { vuggy porosity, massive bedded. General color } \\
\text { trend from top to bottom is pale-yellow changing to } \\
\text { gray. Some high-angle fractures from 83.0' to } \\
\text { 86.4': lower contact sharp. }\end{array}$ \\
\hline
\end{tabular}




\section{Appendix 1B. Site 1, bedrock.-Continued}

\begin{tabular}{|c|c|c|c|c|}
\hline 94.7 & 96.9 & 2.2 & 23.9 & $\begin{array}{l}\text { Dolomite, light gray (5Y 7/1) to pale yellow (5Y } \\
8 / 2 \text { ), fine crystalline intervals } 94.7 \text { ' to } 95.1 \text { ' and } \\
\text { form } 97.0 \text { ' to } 97.4 \text { ' with medium to coarse } \\
\text { crystalline intervals between, clean to slightly } \\
\text { argillaceous, sucrosic, moldic, to vuggy porosity, } \\
\text { high angle fractures, massive bedded. Lower } \\
\text { contact at base of lower fine crystalline zone. }\end{array}$ \\
\hline 96.9 & 103.0 & 6.1 & 30.0 & $\begin{array}{l}\text { Dolomite, pale yellow (5Y 8/2) to light gray (5Y } \\
\text { 7/2), coarse to medium crystalline, slightly } \\
\text { argillaceous to clean, with zones of fine crystalline } \\
\text { dolomite pale yellow (5Y8/2) somewhat friable } \\
\text { dominated by well-developed moldic and } \\
\text { intercrystalline porosity. High angle fractures from } \\
\text { 99.4' to } 100.8 \text { '. }\end{array}$ \\
\hline 103.0 & 108.7 & 5.7 & 35.7 & $\begin{array}{l}\text { Dolomite, pale yellow (5Y 8/2) to light gray (5Y } \\
7 / 1 \text { ), fine to coarse crystaline, moldic, vuggy, and } \\
\text { intercrystalline porosity containing thin to medium } \\
\text { beds of light pale yellow ( } 5 Y 8 / 4) \text {. High-angle } \\
\text { fractures from } 103.4 \text { ' to } 103.7 \text { ', from } 104.6 \text { ' to } \\
105.0 \text { ', } 106.0 \text { to } 107.5 \text { '. Shale laminae, light } \\
\text { greenish gray (Gley1 } 7 / 1 \text { ), soft, present in the } \\
\text { interval from } 104.3 \text { to } 105.2 \text { '. }\end{array}$ \\
\hline 108.7 & 118.2 & 9.5 & 45.2 & $\begin{array}{l}\text { Dolomite, light gray (5Y7/1), coarse crystalline } \\
\text { with thin intervals of fine to medium crystalline, } \\
\text { clean to slightly argillaceous, moldic and } \\
\text { intercrystalline porosity, with some intervals of } \\
\text { vuggy porosity, generally massive bedded. High } \\
\text { angle fractures at } 115.0 \text { '. }\end{array}$ \\
\hline 118.2 & 124.6 & 6.4 & 51.6 & $\begin{array}{l}\text { Dolomite, pale yellow (5Y 8/2) to light gray (5Y } \\
\text { 7/1), generally fine to medium crystalline, minor } \\
\text { intercrystalline to fine moldic porosity, massive } \\
\text { bedded, , medium gray (2.5Y 5/1) argillaceous } \\
\text { laminae from } 121.2 \text { to } 121.6 \text { '. Distinct pale yellow } \\
\text { zone from } 122.8 \text { ' to } 124.6 \text { '. Lower contact sharp at } \\
\text { color change at base of pale yellow zone. }\end{array}$ \\
\hline 124.6 & 146.7 & 22.1 & 73.7 & $\begin{array}{l}\text { Dolomite, light gray (5Y 7/1), coarse crystalline, } \\
\text { well developed moldic, vuggy, and intercrystaline } \\
\text { porosity throughout, massive bedded, clean to } \\
\text { slightly argillaceous, with thin zones of sucrosic, } \\
\text { fine crystalline dolomite; high angle fractures at } \\
129.6 \text { '. Some yellow (2.5Y } 7 / 8 \text { ) iron stain along } \\
\text { bedding planes at } 138.6 \text { ' to } 137.3 \text { ', at } 141.0 \text { ', and } \\
142.1 \text { '. }\end{array}$ \\
\hline 146.7 & 149.8 & 3.1 & 76.8 & $\begin{array}{l}\text { Dolomite, light gray (5Y } 7 / 1 \text { ), fine to coarse } \\
\text { crystalline, thin to massive bedded, thin zones of } \\
\text { moldic and intercrystaline porosity, with } \\
\text { moderately indurated, gray ( } 5 Y \text { Y } 6 / 1 \text { ), dolomitic, } \\
\text { shale laminae that are discontinuous, soft from } \\
146.7 \text { ' to } 147.3 \text { ' and from } 148.5 \text { ' to } 148.7 \text { '. }\end{array}$ \\
\hline 149.8 & 154.6 & 4.8 & 81.6 & $\begin{array}{l}\text { Dolomite, light gray (5Y7/1) to gray (5Y 6/1), } \\
\text { mottled, coarse crystalline, massive bedded, } \\
\text { abundant moldic and intercrystalline porosity, } \\
\text { grades downward into pale yellow ( } 5 \text { Y } 8 / 2 \text { ) } \\
\text { dolomite in lowest } 1.00 \text { '. Lower contact sharp at } \\
\text { interface with chert nodule. A pproximate base of } \\
\text { the L ockport Dolomite. }\end{array}$ \\
\hline
\end{tabular}




\section{Appendix 1B. Site 1, bedrock.-Continued}

\begin{tabular}{|r|r|r|r|l||}
\hline 154.6 & 158.1 & 3.5 & 85.1 & $\begin{array}{l}\text { Dolomite, light gray (5Y 7/2) to pale yellow (5Y } \\
\text { 8/2), fine crystalline with minor thin intervals of } \\
\text { coarse, sucrosic dolomite beds; intercrystalline and } \\
\text { moldic porosity in upper 3 feet. Chert, light gray } \\
\text { (5Y 7/1) to white (5Y 8/1), mottled, nodular } \\
\text { bedded, fossil remnants and dark pyritic or } \\
\text { manganese (?)-rich zones. Sparse greenish gray } \\
\text { (Gley1 4/1), discontinuous, dolomitic shale } \\
\text { laminae. A pproximate top of the Laurel } \\
\text { Dolomite. }\end{array}$ \\
\hline 158.1 & 169.2 & 11.1 & 96.2 & $\begin{array}{l}\text { Limestone, mottled light gray (5Y 7/1) to pale } \\
\text { yellow (5Y 8/2), dolomitic, fine to medium } \\
\text { cystalline, nodular bedded; chert, light grey to } \\
\text { white (Gley1 7/1) (Gley1 8/1) with pyrite and } \\
\text { manganese in chert. Lower contact gradational. }\end{array}$ \\
\hline 169.2 & 177.0 & 7.8 & 104.0 & $\begin{array}{l}\text { Limestone, greenish gray (Gley1 6/1) to dark } \\
\text { greenish gray (Gley1 4/1), dolomitic, argillaceous, } \\
\text { bioclastic, mottled, minor chert nodules that are } \\
\text { light gray (Gley2 7/1); interval is mottled in the } \\
\text { lowermost 2 feet, dolomitic, and argillaceous more } \\
\text { thin above. }\end{array}$ \\
\hline 177.0 & & & & \\
\hline
\end{tabular}




\title{
Appendix 2. Core log descriptions compiled by the Ohio Department of Natural Resources, Division of Geological Survey-Site 2.
}

\author{
STATE OF OHIO \\ DEPARTMENT OF NATURAL RESOURCES \\ DIVISION OF GEOLOGICAL SURVEY
}

CORE LOG

File Number: 3572

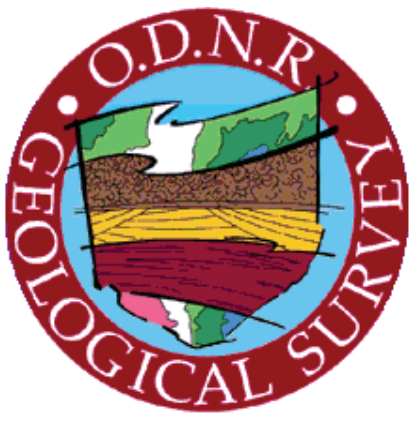

FILE NO.: 3572

COUNTY: Preble

TOWNSHIP: Monroe

SECTION: T9N, R2E, Sec. 17

QUADRANGLE: New Madison 7.5-min.

FIELD NO.: MCD 3, Hole 5

MEASURED BY: R. R. Pavey, E. M. Swinford

DATE: Aug. 19 \& 26, 2004

STATE PLANE SOUTH 1983 COORDINATES: X: 1,357,661 Y: 690,897

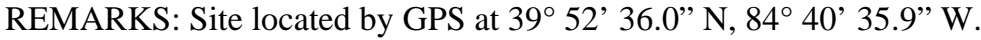

7160 State Rt.726, Eldorado, OH 45321. Hole was drilled for the U.S. Geological Survey, Water

Resources Division, Columbus, OH. Geology was supervised by Mary Ann Thomas of the USGS for an arsenic in groundwater investigation. Drilled by Bowser-Morner with a rotosonic rig producing 4" continuous core.

\begin{tabular}{|r|r|r|r|l||}
\hline $\begin{array}{c}\text { Top of } \\
\text { interval (in } \\
\text { feet) }\end{array}$ & $\begin{array}{c}\text { Bottom of } \\
\text { interval (in } \\
\text { feet) }\end{array}$ & $\begin{array}{c}\text { linterval } \\
\text { thickness } \\
\text { (in feet) }\end{array}$ & $\begin{array}{c}\text { Cumulative } \\
\text { thickness (in } \\
\text { feet) }\end{array}$ & \multicolumn{1}{|c||}{ Description } \\
\hline 0.0 & .8 & .8 & .8 & $\begin{array}{l}\text { Silt, some sand, few pebbles, light to medium } \\
\text { brown, many roots, friable, non-calcareous. }\end{array}$ \\
\hline .8 & 2.2 & 1.4 & 2.2 & $\begin{array}{l}\text { Clayey silty till, common pebbles, medium brown, } \\
\text { mottled with orange-brown, common black organic } \\
\text { pods, weakly calcareous at 1.8 ft. }\end{array}$ \\
\hline 2.2 & 3.9 & 1.7 & 3.9 & $\begin{array}{l}\text { Silty sandy till, common pebbles, medium brown, } \\
1.5 \text { pebble at 3.2 ft., calcareous, massive. }\end{array}$ \\
\hline 3.9 & 10.0 & 6.1 & 10.0 & No core recovery. \\
\hline 10.0 & 10.5 & .5 & 10.5 & $\begin{array}{l}\text { Muddy poorly sorted fine sand to fine gravel, light } \\
\text { to medium brown, fluid, calcareous. }\end{array}$ \\
\hline 10.5 & 12.5 & 2.0 & 12.5 & $\begin{array}{l}\text { Silty sandy till, common pebbles, mottled medium } \\
\text { yellow-brown to medium brownish gray, irregular } \\
\text { horizontal parting, calcareous. }\end{array}$ \\
\hline 12.5 & 14.2 & 1.7 & 14.2 & $\begin{array}{l}\text { Silty sandy till, common pebbles, medium gray } \\
\text { with medium yellow-brown oxidation on joint } \\
\text { faces, calcareous. }\end{array}$ \\
\hline 14.2 & 29.1 & 14.9 & 29.1 & $\begin{array}{l}\text { Silty sandy till, common pebbles, medium gray, } \\
\text { calcareous, massive. }\end{array}$ \\
\hline 29.1 & 30.0 & .9 & 30.0 & $\begin{array}{l}\text { Silt, light to medium gray, wet, grading downward } \\
\text { to silty very fine sand, light gray, moist, calcareous. }\end{array}$ \\
\hline 32.0 & 32.8 & 2.8 & 32.8 & No core recovery. \\
\hline & 33.9 & 1.1 & 33.9 & $\begin{array}{l}\text { Very fine sand to silt, grayish brown, wet, } \\
\text { calcareous. }\end{array}$ \\
\hline & & & & \\
\hline
\end{tabular}




\section{Appendix 2. Site 2.-Continued}

\begin{tabular}{|c|c|c|c|c|}
\hline 33.9 & 35.7 & 1.8 & 35.7 & $\begin{array}{l}\text { Medium sand to small cobbles, brown, poorly } \\
\text { sorted, wet, calcareous. }\end{array}$ \\
\hline 35.7 & 36.2 & .5 & 36.2 & Silty sandy till, medium yellow-brown, calcareous. \\
\hline 36.2 & 36.6 & .4 & 36.6 & Fine sand, light brown, wet, calcareous. \\
\hline 36.6 & 37.2 & .6 & 37.2 & $\begin{array}{l}\text { Medium sand to 1” pebbles, brown, poorly sorted, } \\
\text { wet, calcareous. }\end{array}$ \\
\hline 37.2 & 40.0 & 2.8 & 40.0 & Silty sandy till, grayish brown, calcareous, massive. \\
\hline 40.0 & 41.0 & 1.0 & 41.0 & No core recovery. \\
\hline 41.0 & 41.2 & .2 & 41.2 & Medium to coarse sand, brown, wet, calcareous. \\
\hline 41.2 & 48.3 & 7.1 & 48.3 & $\begin{array}{l}\text { Silty sandy till, medium brownish gray, calcareous, } \\
\text { massive. }\end{array}$ \\
\hline 48.3 & 52.4 & 4.1 & 52.4 & $\begin{array}{l}\text { Medium sand to medium gravel, grayish brown, } \\
\text { with fragments of silty fine sand to medium gravel, } \\
\text { dark brownish gray, cohesive, friable, calcareous. }\end{array}$ \\
\hline 52.4 & 53.0 & .6 & 53.0 & $\begin{array}{l}\text { Silty fine sand to fine gravel, medium brown, } \\
\text { cohesive, calcareous. }\end{array}$ \\
\hline 53.0 & 56.0 & 3.0 & 56.0 & $\begin{array}{l}\text { Silt to fine sand, some grains of coarse sand to fine } \\
\text { gravel, light to medium brown, calcareous, moist, } \\
\text { grading downward to silt and fine sand with some } \\
\text { clay, medium brown, calcareous, moist. }\end{array}$ \\
\hline 56.0 & 60.0 & 4.0 & 60.0 & $\begin{array}{l}\text { Silty sandy till, common pebbles, light to medium } \\
\text { brown grading downward to grayish brown, } \\
\text { calcareous, some platy structure in upper } 2.4 \mathrm{ft} \text {., } \\
\text { dry. }\end{array}$ \\
\hline 60.0 & 69.3 & 9.3 & 69.3 & $\begin{array}{l}\text { Silt and fine sand, medium brown, well sorted, } \\
\text { calcareous, moist. }\end{array}$ \\
\hline 69.3 & 71.7 & 2.4 & 71.7 & $\begin{array}{l}\text { Medium sand, medium brown, well sorted, } \\
\text { calcareous, moist. }\end{array}$ \\
\hline 71.7 & 78.8 & 7.1 & 78.8 & $\begin{array}{l}\text { Fine to medium sand, medium brown, calcareous, } \\
\text { moist, with clasts of silty fine sand, dark brown, } \\
\text { cohesive, calcareous, moist. }\end{array}$ \\
\hline 78.8 & 80.0 & 1.2 & 80.0 & $\begin{array}{l}\text { Clayey silt, mottled dark gray to dark grayish } \\
\text { brown, calcareous, moist. }\end{array}$ \\
\hline 80.0 & 80.7 & .7 & 80.7 & $\begin{array}{l}\text { Fine to medium sand, medium brown, calcareous, } \\
\text { moist, with clasts of silty fine sand, dark brown, } \\
\text { cohesive, calcareous, moist. }\end{array}$ \\
\hline 80.7 & 90.0 & 9.3 & 90.0 & $\begin{array}{l}\text { Clayey silt, medium brown to grayish brown, } \\
\text { calcareous, massive, moderately plastic, moist. }\end{array}$ \\
\hline 90.0 & 90.5 & .5 & 90.5 & $\begin{array}{l}\text { Silt, dark brownish gray, some pebbles in lower } \\
\text { part, leached. Probable paleosol. }\end{array}$ \\
\hline 90.5 & 91.7 & 1.2 & 91.7 & $\begin{array}{l}\text { Clayey silt till, many pebbles, medium to dark } \\
\text { brown with common black organic streaks, weakly } \\
\text { calcareous to leached, moist, HCl releases odor of } \\
\text { sulfuric compound, organic odor on fresh break. } \\
\text { Probable paleosol. }\end{array}$ \\
\hline 91.7 & 102.7 & 11.0 & 102.7 & $\begin{array}{l}\text { Clayey silt till, medium to dark brown, moderately } \\
\text { calcareous, moist, very broken, becoming } \\
\text { fragmented and muddy with depth, organic odor on } \\
\text { fresh break. }\end{array}$ \\
\hline 102.7 & 104.7 & 2.0 & 104.7 & Silt, medium brown, calcareous, broken. \\
\hline 104.7 & 107.1 & 2.4 & 107.1 & $\begin{array}{l}\text { Clayey silt till, dark brown, very calcareous, hard, } \\
\text { dry. }\end{array}$ \\
\hline 107.1 & 108.3 & 1.2 & 108.3 & $\begin{array}{l}\text { Very fine sand and silt grading downward from } \\
\text { light brown to nearly white, weakly calcareous, } \\
\text { moist. Probable paleosol. }\end{array}$ \\
\hline
\end{tabular}




\section{Appendix 2. Site 2.-Continued}

\begin{tabular}{||r|r|r|c|l||}
\hline 108.3 & 110.0 & 1.7 & 110.0 & $\begin{array}{l}\text { Dolomite fragments, with very fine sand, silt, and } \\
\text { clay, light tan, weakly calcareous. Probable } \\
\text { paleosol. }\end{array}$ \\
\hline 110.00 & 112.0 & 2.00 & 112.00 & $\begin{array}{l}\text { Dolomite, pale-yellow (5Y 8/2) to light gray (N7), } \\
\text { fine to medium crystalline, intercrystalline and } \\
\text { moldic porosity, massive bedded; yellowish-brown } \\
\text { iron stain along select bedding planes; lower } \\
\text { contact in missing interval. }\end{array}$ \\
\hline 112.00 & 112.3 & .30 & 112.3 & Missing interval. \\
\hline 112.3 & 114.0 & 1.70 & 114.0 & $\begin{array}{l}\text { Dolomite, light-gray (N7) to medium- light gray } \\
\text { (N6), coarse to fine crystalline, slightly } \\
\text { argillaceous, zones of moldic porosity and some } \\
\text { intercrystalline porosity, stylolitic, medium to thin } \\
\text { bedded with thinner bedded zone being more } \\
\text { argillaceous; bedding planes appear water worn. } \\
\text { Lower contact in missing interval. }\end{array}$ \\
\hline 115.5 & 117.4 & 1.90 & 117.4 & $\begin{array}{l}\text { Missing interval. } \\
\text { Dolomite, light-gray (N7) to medium-light gray } \\
\text { (N6), coarse to fine crystalline, slightly } \\
\text { argillaceous, zones of moldic porosity and some } \\
\text { intercrystalline porosity, stylolitic, medium to thin } \\
\text { bedded with thinner bedded zone being more } \\
\text { argillaceous, bedding planes appear water worn. } \\
\text { High angle fractures at 115.5 - 116.3. Lower } \\
\text { contact sharp and undulatory where light gray (N7) } \\
\text { dolomite in sharp contact with medium light gray } \\
\text { (N6) dolomite with medium gray (N5) .03 layer at } \\
\text { contact. }\end{array}$ \\
\hline 117.4 & 119.6 & 2.20 & 119.6 & $\begin{array}{l}\text { Dolomite, light gray (N7), light medium gray (N6) } \\
\text { to light olive gray (5Y 6/1), fine to medium } \\
\text { crystalline, light gray chert, fossil brachiopods } \\
\text { molds, intercrystalline porosity with moldic } \\
\text { porosity along bedding planes, stylolitic in part, } \\
\text { medium to thin bedded; core broken along bedding } \\
\text { planes. Rock core is Silurian Lockport Dolomite. } \\
\text { Total Depth. }\end{array}$ \\
\hline
\end{tabular}


Appendix 3A. Bulk elemental composition of solid-phase samples, site 1.

[<, less than; pct, percent; ppm, parts per million; ppm is equivalent to milligrams per kilogram]

\begin{tabular}{|c|c|c|c|c|c|c|c|c|}
\hline $\begin{array}{r}\text { Depth } \\
\text { (feet) }\end{array}$ & $\begin{array}{c}\text { Organic } \\
\text { carbon } \\
\text { (pct) }\end{array}$ & $\begin{array}{c}\text { Total } \\
\text { carbon } \\
\text { (pct) }\end{array}$ & $\begin{array}{c}\mathrm{CO}_{2} \\
\text { (pct) }\end{array}$ & $\begin{array}{c}\text { Carbonate } \\
\text { carbon } \\
\text { (pct) }\end{array}$ & $\begin{array}{c}\text { Total } \\
\text { sulfur } \\
\text { (pct) }\end{array}$ & $\begin{array}{l}\text { Alum- } \\
\text { inum } \\
\text { (pct) }\end{array}$ & $\begin{array}{c}\text { Calcium } \\
\text { (pct) }\end{array}$ & $\begin{array}{l}\text { Iron } \\
\text { (pct) }\end{array}$ \\
\hline 30.3 & -0.44 & 8.23 & 31.76 & 8.67 & 0.05 & 1.72 & 17.26 & 0.85 \\
\hline 31.3 & 0.22 & 5.35 & 18.81 & 5.13 & 0.05 & 2.65 & 11.35 & 1.06 \\
\hline 32 & 0.29 & 8.97 & 31.79 & 8.68 & 0.06 & 1.61 & 16.01 & 0.77 \\
\hline 33 & 0.27 & 9.12 & 32.43 & 8.85 & 0.06 & 1.25 & 15.9 & 0.67 \\
\hline 33.3 & 0.12 & 8.02 & 28.95 & 7.9 & 0.07 & 1.67 & 14.74 & 0.77 \\
\hline 34 & 0.49 & 9.4 & 32.65 & 8.91 & 0.07 & 1.23 & 17.52 & 0.66 \\
\hline 34.8 & 0.19 & 1.62 & 5.25 & 1.43 & $<0.05$ & 5.54 & 4.72 & 1.96 \\
\hline 42 & 0.42 & 5.73 & 19.44 & 5.31 & 0.1 & 2.92 & 11.44 & 1.69 \\
\hline 48 & 0.39 & 5.84 & 19.97 & 5.45 & 0.16 & 2.4 & 12.77 & 1.21 \\
\hline 49 & 0.7 & 6.89 & 22.68 & 6.19 & 0.21 & 1.96 & 13.72 & 1.12 \\
\hline 52.5 & 0.3 & 6.34 & 22.12 & 6.04 & 0.22 & 2.22 & 13.78 & 1.26 \\
\hline 57.8 & 0.23 & 0.5 & 0.98 & 0.27 & $<0.05$ & 4.48 & 1.31 & 7.93 \\
\hline 58 & 0.24 & 0.38 & 0.52 & 0.14 & $<0.05$ & 5.78 & 1.04 & 4.6 \\
\hline 58.5 & 0.42 & 0.58 & 0.58 & 0.16 & $<0.05$ & 6.62 & 0.89 & 7.3 \\
\hline 62.4 & 0.13 & 0.29 & 0.58 & 0.16 & $<0.05$ & 5.82 & 0.94 & 5.38 \\
\hline 67.1 & 0.71 & 3.16 & 8.99 & 2.45 & 0.34 & 5.14 & 6.12 & 2.69 \\
\hline 73 & 1.75 & 13.9 & 44.51 & 12.15 & $<0.05$ & 0.06 & 20.26 & 0.06 \\
\hline 75.4 & -1 & 11.7 & 46.52 & 12.7 & $<0.05$ & 0.03 & 20.03 & 0.06 \\
\hline 77 & -0.07 & 6.15 & 22.8 & 6.22 & 0.09 & 6.55 & 11.11 & 3.08 \\
\hline 80 & -1.02 & 11.6 & 46.25 & 12.62 & $<0.05$ & 0.05 & 19.95 & 0.14 \\
\hline 82 & -2.15 & 10.6 & 46.7 & 12.75 & $<0.05$ & 0.03 & 19.93 & 0.16 \\
\hline 83 & -0.43 & 12.2 & 46.26 & 12.63 & $<0.05$ & 0.02 & 19.71 & 0.11 \\
\hline 84 & -0.58 & 12.1 & 46.46 & 12.68 & $<0.05$ & 0.03 & 19.87 & 0.12 \\
\hline 85 & -0.6 & 12.1 & 46.53 & 12.7 & $<0.05$ & 0.04 & 19.82 & 0.1 \\
\hline 86 & 0.09 & 12.4 & 45.09 & 12.31 & $<0.05$ & 0.02 & 19.87 & 0.14 \\
\hline 87 & -0.25 & 12.5 & 46.73 & 12.75 & $<0.05$ & 0.01 & 19.74 & 0.17 \\
\hline 88 & -0.33 & 11.9 & 44.81 & 12.23 & $<0.05$ & 0.02 & 20.04 & 0.23 \\
\hline 92 & -0.24 & 12.4 & 46.33 & 12.64 & $<0.05$ & 0.01 & 19.71 & 0.21 \\
\hline 95.5 & -0.36 & 12.2 & 46.01 & 12.56 & $<0.05$ & 0.06 & 19.68 & 0.09 \\
\hline 99.4 & 0.22 & 12.2 & 43.91 & 11.98 & $<0.05$ & 0.09 & 19.65 & 0.11 \\
\hline 104.5 & -0.37 & 12 & 45.32 & 12.37 & $<0.05$ & 0.24 & 19.86 & 0.09 \\
\hline 116.5 & 0.38 & 12.7 & 45.13 & 12.32 & $<0.05$ & 0.05 & 19.59 & 0.08 \\
\hline 123.5 & -0.36 & 11.3 & 42.74 & 11.66 & $<0.05$ & 0.42 & 19.44 & 0.29 \\
\hline 140.5 & -0.41 & 12.5 & 47.3 & 12.91 & $<0.05$ & 0.09 & 18.75 & 0.13 \\
\hline 154.5 & -0.17 & 12.1 & 44.94 & 12.27 & $<0.05$ & 0.2 & 19.39 & 0.14 \\
\hline 160.3 & 0.01 & 0.05 & 0.13 & 0.04 & 1.07 & 0.11 & 0.11 & 1.28 \\
\hline
\end{tabular}




\section{Appendix 3A. Bulk elemental composition of solid-phase samples, site 1.-Continued}

[<, less than; pct, percent; ppm, parts per million; ppm is equivalent to milligrams per kilogram]

\begin{tabular}{|c|c|c|c|c|c|c|c|c|}
\hline $\begin{array}{l}\text { Depth } \\
\text { (feet) }\end{array}$ & $\begin{array}{l}\text { Potas- } \\
\text { sium } \\
\text { (pct) }\end{array}$ & $\begin{array}{c}\text { Magnes- } \\
\text { ium } \\
\text { (pct) }\end{array}$ & $\begin{array}{c}\text { Sodium } \\
\text { (pct) }\end{array}$ & $\begin{array}{c}\text { Sulfur } \\
\text { (pct) }\end{array}$ & $\begin{array}{l}\text { Titanium } \\
\text { (pct) }\end{array}$ & $\begin{array}{l}\text { Silver } \\
\text { (ppm) }\end{array}$ & $\begin{array}{c}\text { Arsenic } \\
\text { (ppm) }\end{array}$ & $\begin{array}{c}\text { Barium } \\
\text { (ppm) }\end{array}$ \\
\hline 30.3 & 0.71 & 8.38 & 0.44 & 0.1 & 0.06 & $<1$ & 2 & 241 \\
\hline 31.3 & 1.01 & 4.93 & 0.82 & 0.09 & 0.08 & $<1$ & 2 & 322 \\
\hline 32 & 0.74 & 7.42 & 0.34 & 0.12 & 0.04 & $<1$ & 3 & 188 \\
\hline 33 & 0.53 & 6.9 & 0.29 & 0.1 & 0.03 & $<1$ & 3 & 172 \\
\hline 33.3 & 0.71 & 6.69 & 0.43 & 0.1 & 0.04 & $<1$ & 3 & 211 \\
\hline 34 & 0.56 & 8.17 & 0.27 & 0.13 & 0.04 & $<1$ & 3 & 152 \\
\hline 34.8 & 1.85 & 1.82 & 1.95 & 0.05 & 0.14 & $<1$ & 2 & 449 \\
\hline 42 & 1.09 & 4.46 & 0.63 & 0.12 & 0.1 & $<1$ & 6 & 270 \\
\hline 48 & 0.95 & 4.67 & 0.64 & 0.24 & 0.07 & $<1$ & 5 & 237 \\
\hline 49 & 0.78 & 5.21 & 0.49 & 0.26 & 0.07 & $<1$ & 5 & 204 \\
\hline 52.5 & 0.84 & 5.06 & 0.6 & 0.28 & 0.08 & $<1$ & 6 & 222 \\
\hline 57.8 & 1.4 & 0.69 & 0.79 & 0.02 & 0.16 & $<1$ & 14 & 371 \\
\hline 58 & 1.87 & 0.84 & 0.86 & 0.01 & 0.19 & $<1$ & 11 & 465 \\
\hline 58.5 & 2.18 & 0.9 & 0.58 & 0.02 & 0.15 & $<1$ & 20 & 503 \\
\hline 62.4 & 1.63 & 0.72 & 0.71 & 0.02 & 0.16 & $<1$ & 9 & 464 \\
\hline 67.1 & 1.52 & 2.4 & 0.61 & 0.4 & 0.16 & $<1$ & 11 & 398 \\
\hline 73 & 0.03 & 11.68 & 0.02 & 0.04 & $<0.01$ & $<1$ & 4 & 8 \\
\hline 75.4 & 0.01 & 11.58 & 0.02 & 0.01 & $<0.01$ & $<1$ & $<1$ & 5 \\
\hline 77 & 0.67 & 6.87 & 0.08 & 0.13 & 0.14 & $<1$ & 42 & 188 \\
\hline 80 & 0.01 & 11.61 & 0.02 & 0.01 & $<0.01$ & $<1$ & $<1$ & 8 \\
\hline 82 & $<0.01$ & 11.63 & 0.02 & 0.01 & $<0.01$ & $<1$ & $<1$ & $<5$ \\
\hline 83 & $<0.01$ & 11.57 & 0.02 & $<0.01$ & $<0.01$ & $<1$ & $<1$ & $<5$ \\
\hline 84 & 0.01 & 11.7 & 0.02 & 0.01 & $<0.01$ & $<1$ & $<1$ & $<5$ \\
\hline 85 & $<0.01$ & 11.52 & 0.03 & 0.02 & $<0.01$ & $<1$ & $<1$ & 5 \\
\hline 86 & $<0.01$ & 11.59 & 0.02 & 0.01 & $<0.01$ & $<1$ & $<1$ & $<5$ \\
\hline 87 & $<0.01$ & 11.41 & 0.02 & 0.01 & $<0.01$ & $<1$ & $<1$ & $<5$ \\
\hline 88 & $<0.01$ & 11.53 & 0.03 & 0.01 & $<0.01$ & $<1$ & $<1$ & $<5$ \\
\hline 92 & $<0.01$ & 11.44 & 0.02 & 0.02 & $<0.01$ & $<1$ & $<1$ & $<5$ \\
\hline 95.5 & $<0.01$ & 11.44 & 0.03 & 0.03 & $<0.01$ & $<1$ & 1 & 6 \\
\hline 99.4 & $<0.01$ & 11.49 & 0.03 & 0.03 & $<0.01$ & $<1$ & $<1$ & 6 \\
\hline 104.5 & 0.11 & 11.52 & 0.02 & 0.02 & $<0.01$ & $<1$ & $<1$ & 12 \\
\hline 116.5 & 0.02 & 11.46 & 0.04 & 0.05 & $<0.01$ & $<1$ & $<1$ & $<5$ \\
\hline 123.5 & 0.24 & 11.32 & 0.02 & 0.02 & 0.02 & $<1$ & $<1$ & 22 \\
\hline 140.5 & 0.04 & 10.91 & 0.03 & 0.03 & $<0.01$ & $<1$ & 1 & 8 \\
\hline 154.5 & 0.1 & 11.13 & 0.03 & 0.05 & $<0.01$ & $<1$ & $<1$ & 12 \\
\hline 160.3 & 0.03 & 0.06 & 0.03 & 1.28 & $<0.01$ & $<1$ & 2 & 32 \\
\hline
\end{tabular}




\section{Appendix 3A. Bulk elemental composition of solid-phase samples, site 1.-Continued}

[<, less than; pct, percent; ppm, parts per million; ppm is equivalent to milligrams per kilogram. Organic carbon concentrations were computed by subtracting carbonate carbon from total carbon concentrations; negative values for organic carbon are due to small amounts of measurement error.]

\begin{tabular}{|c|c|c|c|c|c|c|c|c|}
\hline $\begin{array}{l}\text { Depth } \\
\text { (feet) }\end{array}$ & $\begin{array}{c}\text { Beryllium } \\
\text { (ppm) }\end{array}$ & $\begin{array}{c}\text { Bismuth } \\
\text { (ppm) }\end{array}$ & $\begin{array}{c}\text { Cadmium } \\
\text { (ppm) }\end{array}$ & $\begin{array}{c}\text { Cerium } \\
\text { (ppm) }\end{array}$ & $\begin{array}{l}\begin{array}{l}\text { Cobalt } \\
\text { (ppm) }\end{array} \\
\end{array}$ & $\begin{array}{c}\text { Chromium } \\
\text { (ppm) }\end{array}$ & $\begin{array}{c}\text { Cesium } \\
\text { (ppm) }\end{array}$ & $\begin{array}{c}\text { Copper } \\
\text { (ppm) }\end{array}$ \\
\hline 30.3 & 0.6 & $<0.04$ & $<0.1$ & 16.1 & 2.5 & 11 & 0.6 & 8.7 \\
\hline 31.3 & 0.8 & $<0.04$ & $<0.1$ & 20.9 & 3.1 & 15 & 0.7 & 7.8 \\
\hline 32 & 0.6 & 0.05 & 0.1 & 16.6 & 2.9 & 10 & 0.88 & 10.2 \\
\hline 33 & 0.5 & $<0.04$ & 0.1 & 13.2 & 3.2 & 9 & 0.68 & 8.7 \\
\hline 33.3 & 0.5 & $<0.04$ & $<0.1$ & 16.5 & 2.7 & 11 & 0.72 & 8.9 \\
\hline 34 & 0.4 & $<0.04$ & 0.1 & 12 & 2.8 & 9 & 0.58 & 11.5 \\
\hline 34.8 & 1.3 & 0.07 & $<0.1$ & 43.1 & 9.2 & 44 & 1.54 & 19.8 \\
\hline 42 & 0.8 & 0.07 & 0.2 & 29.2 & 5.9 & 20 & 1.63 & 15.4 \\
\hline 48 & 0.7 & 0.07 & 0.1 & 25.3 & 4.5 & 18 & 0.97 & 11.4 \\
\hline 49 & 0.7 & 0.07 & 0.2 & 18.2 & 4.3 & 16 & 0.83 & 12.8 \\
\hline 52.5 & 0.7 & 0.08 & 0.2 & 20.3 & 6.1 & 21 & 0.83 & 12.2 \\
\hline 57.8 & 1.7 & 0.1 & 0.4 & 41.3 & 13.1 & 32 & 2.44 & 23.8 \\
\hline 58 & 1.9 & 0.1 & 0.2 & 54.9 & 12.2 & 42 & 3.6 & 27.1 \\
\hline 58.5 & 2.1 & 0.13 & 0.3 & 61.5 & 17.1 & 53 & 6.03 & 31.1 \\
\hline 62.4 & 1.7 & 0.1 & 0.2 & 50.1 & 11.5 & 47 & 3.72 & 24.6 \\
\hline 67.1 & 1.5 & 0.18 & 0.2 & 47.9 & 14.1 & 39 & 3.75 & 21.5 \\
\hline 73 & $<0.1$ & $<0.04$ & $<0.1$ & 1.76 & 5.8 & 3 & 0.05 & 5.7 \\
\hline 75.4 & $<0.1$ & $<0.04$ & $<0.1$ & 1.7 & 0.4 & 3 & $<0.05$ & 4.5 \\
\hline 77 & 2.1 & 0.11 & 0.3 & 17.1 & 18.3 & 45 & 5.85 & 28.6 \\
\hline 80 & $<0.1$ & $<0.04$ & $<0.1$ & 1.64 & 0.4 & 2 & $<0.05$ & 5.2 \\
\hline 82 & $<0.1$ & $<0.04$ & $<0.1$ & 1.36 & 0.4 & 2 & $<0.05$ & 4.7 \\
\hline 83 & $<0.1$ & $<0.04$ & $<0.1$ & 1.04 & 0.3 & 2 & $<0.05$ & 5.2 \\
\hline 84 & $<0.1$ & $<0.04$ & $<0.1$ & 1.68 & 0.4 & 2 & $<0.05$ & 5 \\
\hline 85 & $<0.1$ & $<0.04$ & $<0.1$ & 1.83 & 0.4 & $<1$ & $<0.05$ & 5.7 \\
\hline 86 & $<0.1$ & $<0.04$ & $<0.1$ & 1.02 & 0.4 & 1 & $<0.05$ & 7.2 \\
\hline 87 & $<0.1$ & $<0.04$ & $<0.1$ & 1.48 & 0.4 & $<1$ & $<0.05$ & 4.7 \\
\hline 88 & $<0.1$ & $<0.04$ & $<0.1$ & 1.12 & 0.4 & 2 & $<0.05$ & 6.4 \\
\hline 92 & $<0.1$ & $<0.04$ & 0.2 & 0.84 & 0.4 & 1 & $<0.05$ & 4.9 \\
\hline 95.5 & $<0.1$ & $<0.04$ & $<0.1$ & 1.25 & 0.6 & 2 & $<0.05$ & 5.9 \\
\hline 99.4 & $<0.1$ & $<0.04$ & $<0.1$ & 1.46 & 0.6 & 2 & $<0.05$ & 7.9 \\
\hline 104.5 & $<0.1$ & $<0.04$ & $<0.1$ & 4.11 & 0.5 & 3 & 0.18 & 5.3 \\
\hline 116.5 & $<0.1$ & $<0.04$ & $<0.1$ & 4.8 & 0.5 & 1 & $<0.05$ & 5.2 \\
\hline 123.5 & 0.1 & $<0.04$ & $<0.1$ & 9.06 & 0.9 & 6 & 0.31 & 5.3 \\
\hline 140.5 & $<0.1$ & $<0.04$ & $<0.1$ & 5.88 & 0.6 & 2 & $<0.05$ & 5 \\
\hline 154.5 & $<0.1$ & $<0.04$ & $<0.1$ & 6.76 & 0.5 & 5 & 0.23 & 4.4 \\
\hline 160.3 & $<0.1$ & $<0.04$ & 0.1 & 0.26 & 0.6 & 2 & $<0.05$ & 1.1 \\
\hline
\end{tabular}




\section{Appendix 3A. Bulk elemental composition of solid-phase samples, site 1.-Continued}

[<, less than; pct, percent; ppm, parts per million; ppm is equivalent to milligrams per kilogram]

\begin{tabular}{|c|c|c|c|c|c|c|c|c|}
\hline $\begin{array}{l}\text { Depth } \\
\text { (feet) }\end{array}$ & $\begin{array}{c}\text { Gallium } \\
\text { (ppm) }\end{array}$ & $\begin{array}{c}\text { Indium } \\
\text { (ppm) }\end{array}$ & $\begin{array}{c}\text { Lanth- } \\
\text { anum } \\
\text { (ppm) }\end{array}$ & $\begin{array}{l}\text { Lithium } \\
\text { (ppm) }\end{array}$ & $\begin{array}{c}\text { Man- } \\
\text { ganese } \\
\text { (ppm) }\end{array}$ & $\begin{array}{c}\text { Molyb- } \\
\text { denum } \\
\text { (ppm) }\end{array}$ & $\begin{array}{c}\text { Niobium } \\
\text { (ppm) }\end{array}$ & $\begin{array}{c}\text { Nickel } \\
\text { (ppm) }\end{array}$ \\
\hline 30.3 & 3.56 & $<0.02$ & 7.9 & 10 & 291 & 1.64 & 2 & 3.3 \\
\hline 31.3 & 5.48 & $<0.02$ & 9.9 & 8 & 286 & 1.9 & 2.8 & 4.8 \\
\hline 32 & 3.78 & $<0.02$ & 8.5 & 10 & 277 & 2.46 & 2 & 5.5 \\
\hline 33 & 3.02 & $<0.02$ & 6.8 & 8 & 273 & 2.4 & 1.5 & 3.8 \\
\hline 33.3 & 3.8 & $<0.02$ & 8.3 & 9 & 251 & 2.09 & 1.9 & 4.5 \\
\hline 34 & 2.7 & $<0.02$ & 6.3 & 9 & 261 & 1.64 & 1.2 & 2.7 \\
\hline 34.8 & 12.7 & 0.02 & 22.1 & 13 & 369 & 0.66 & 4.7 & 25 \\
\hline 42 & 6.61 & 0.03 & 14.2 & 14 & 447 & 3.18 & 3.7 & 11.7 \\
\hline 48 & 5.3 & $<0.02$ & 12.7 & 10 & 359 & 3.6 & 2.5 & 10.5 \\
\hline 49 & 4.34 & $<0.02$ & 8.9 & 10 & 371 & 3 & 2.2 & 8.5 \\
\hline 52.5 & 4.85 & $<0.02$ & 10.4 & 9 & 388 & 2.86 & 2.4 & 8.5 \\
\hline 57.8 & 9.82 & 0.04 & 21.8 & 18 & 1130 & 7.14 & 4.8 & 27.9 \\
\hline 58 & 13 & 0.06 & 27.9 & 27 & 456 & 4.62 & 6.3 & 32.7 \\
\hline 58.5 & 15.5 & 0.06 & 31.3 & 30 & 614 & 7.5 & 5.3 & 42.4 \\
\hline 62.4 & 12.9 & 0.05 & 25.8 & 25 & 526 & 3.95 & 5.6 & 35.1 \\
\hline 67.1 & 10.9 & 0.05 & 24.2 & 29 & 549 & 8.69 & 5.8 & 21.8 \\
\hline 73 & 0.16 & $<0.02$ & 1.5 & 3 & 58 & 0.43 & 0.2 & 4.7 \\
\hline 75.4 & 0.08 & $<0.02$ & 1.6 & 2 & 108 & $<0.05$ & 0.2 & $<0.5$ \\
\hline 77 & 15.8 & 0.06 & 10.9 & 66 & 160 & 9.53 & 6.7 & 64.4 \\
\hline 80 & 0.15 & $<0.02$ & 1.8 & 2 & 134 & 0.07 & 0.1 & $<0.5$ \\
\hline 82 & 0.1 & $<0.02$ & 1.5 & 2 & 152 & 0.14 & $<0.1$ & $<0.5$ \\
\hline 83 & 0.06 & $<0.02$ & 1 & 2 & 106 & 0.23 & $<0.1$ & $<0.5$ \\
\hline 84 & 0.08 & $<0.02$ & 1.5 & $<1$ & 135 & 0.08 & 0.2 & $<0.5$ \\
\hline 85 & 0.09 & $<0.02$ & 1.7 & 1 & 120 & 0.08 & $<0.1$ & $<0.5$ \\
\hline 86 & 0.07 & $<0.02$ & 1 & 1 & 172 & 0.07 & $<0.1$ & $<0.5$ \\
\hline 87 & 0.05 & $<0.02$ & 1.3 & $<1$ & 135 & $<0.05$ & $<0.1$ & $<0.5$ \\
\hline 88 & 0.08 & $<0.02$ & 1.1 & 2 & 100 & 0.11 & 0.1 & $<0.5$ \\
\hline 92 & 0.06 & $<0.02$ & 0.8 & $<1$ & 129 & 0.06 & $<0.1$ & $<0.5$ \\
\hline 95.5 & 0.16 & $<0.02$ & 1.1 & 1 & 125 & 0.2 & $<0.1$ & $<0.5$ \\
\hline 99.4 & 0.2 & $<0.02$ & 1.3 & 2 & 120 & 0.06 & 0.1 & 1.2 \\
\hline 104.5 & 0.52 & $<0.02$ & 2.8 & 4 & 68 & $<0.05$ & 0.6 & $<0.5$ \\
\hline 116.5 & 0.14 & $<0.02$ & 4.5 & 1 & 99 & 0.07 & 0.2 & $<0.5$ \\
\hline 123.5 & 0.89 & $<0.02$ & 6.6 & 5 & 151 & 0.42 & 0.7 & $<0.5$ \\
\hline 140.5 & 0.29 & $<0.02$ & 4.7 & 2 & 173 & 0.16 & 0.4 & 1.2 \\
\hline 154.5 & 0.48 & $<0.02$ & 6.2 & 3 & 206 & 0.08 & 0.5 & $<0.5$ \\
\hline 160.3 & 0.21 & $<0.02$ & $<0.5$ & 5 & 30 & 0.41 & 0.2 & 8.3 \\
\hline
\end{tabular}




\section{Appendix 3A. Bulk elemental composition of solid-phase samples, site 1.-Continued}

[<, less than; pct, percent; ppm, parts per million; ppm is equivalent to milligrams per kilogram]

\begin{tabular}{|c|c|c|c|c|c|c|c|c|}
\hline $\begin{array}{l}\text { Depth } \\
\text { (feet) }\end{array}$ & $\begin{array}{c}\text { Phosphorus } \\
\text { (ppm) }\end{array}$ & $\begin{array}{l}\text { Lead } \\
\text { (ppm) }\end{array}$ & $\begin{array}{c}\text { Rubidium } \\
\text { (ppm) }\end{array}$ & $\begin{array}{c}\text { Antimony } \\
\text { (ppm) }\end{array}$ & $\begin{array}{c}\text { Scandium } \\
\text { (ppm) }\end{array}$ & $\begin{array}{c}\text { Tin } \\
\text { (ppm) }\end{array}$ & $\begin{array}{c}\text { Strontium } \\
\text { (ppm) }\end{array}$ & $\begin{array}{c}\text { Tellurium } \\
\text { (ppm) }\end{array}$ \\
\hline 30.3 & 206 & 6.1 & 21.5 & 0.16 & 2.5 & 0.4 & 191 & $<0.1$ \\
\hline 31.3 & 306 & 7.9 & 30.3 & 0.18 & 3.5 & 0.5 & 219.4 & $<0.1$ \\
\hline 32 & 185 & 7.3 & 27.3 & 0.23 & 2.7 & 0.4 & 164.3 & $<0.1$ \\
\hline 33 & 148 & 4.8 & 20.8 & 0.2 & 2.2 & 0.3 & 152.3 & $<0.1$ \\
\hline 33.3 & 190 & 5.8 & 24.9 & 0.19 & 2.7 & 0.4 & 172.7 & $<0.1$ \\
\hline 34 & 167 & 4.7 & 19 & 0.18 & 2.2 & 0.4 & 156 & $<0.1$ \\
\hline 34.8 & 414 & 12.4 & 83.5 & 0.17 & 6.9 & 0.9 & 313 & $<0.1$ \\
\hline 42 & 332 & 9.6 & 43.9 & 0.37 & 5.1 & 0.7 & 219.8 & $<0.1$ \\
\hline 48 & 252 & 7.6 & 33 & 0.26 & 3.5 & 0.5 & 206.7 & $<0.1$ \\
\hline 49 & 215 & 7.1 & 27.6 & 0.28 & 3.6 & 0.5 & 193.2 & $<0.1$ \\
\hline 52.5 & 240 & 6.8 & 28.3 & 0.24 & 3.6 & 0.5 & 204.5 & $<0.1$ \\
\hline 57.8 & 697 & 17.6 & 61.6 & 1.39 & 8.4 & 1 & 407.6 & $<0.1$ \\
\hline 58 & 679 & 19.6 & 83.9 & 1.06 & 11 & 2 & 493.6 & $<0.1$ \\
\hline 58.5 & 651 & 21.3 & 117.3 & 1.5 & 12.6 & 1.9 & 562 & $<0.1$ \\
\hline 62.4 & 515 & 19.2 & 85.9 & 0.93 & 10 & 1.3 & 580.1 & $<0.1$ \\
\hline 67.1 & 331 & 16 & 75.2 & 0.59 & 8.3 & 1.4 & 437.5 & $<0.1$ \\
\hline 73 & $<50$ & 1.3 & 1.3 & 0.07 & 0.2 & $<0.1$ & 71.5 & $<0.1$ \\
\hline 75.4 & $<50$ & 0.6 & 0.5 & $<0.05$ & 0.3 & 0.1 & 54.7 & $<0.1$ \\
\hline 77 & 206 & 46.9 & 93.8 & 0.8 & 11.8 & 1.9 & 656.7 & $<0.1$ \\
\hline 80 & $<50$ & 0.9 & 0.8 & $<0.05$ & 0.3 & 0.2 & 58 & $<0.1$ \\
\hline 82 & $<50$ & 0.7 & 0.6 & $<0.05$ & 0.2 & 0.1 & 53 & $<0.1$ \\
\hline 83 & $<50$ & 0.8 & 0.3 & $<0.05$ & 0.1 & $<0.1$ & 49.5 & $<0.1$ \\
\hline 84 & $<50$ & 0.6 & 0.6 & $<0.05$ & 0.2 & $<0.1$ & 49.9 & $<0.1$ \\
\hline 85 & $<50$ & 0.9 & 0.4 & 0.06 & 0.2 & 0.2 & 49.8 & $<0.1$ \\
\hline 86 & $<50$ & 0.7 & 0.3 & $<0.05$ & $<0.1$ & 0.2 & 47.7 & $<0.1$ \\
\hline 87 & $<50$ & 0.5 & 0.2 & $<0.05$ & 0.2 & $<0.1$ & 45.3 & $<0.1$ \\
\hline 88 & $<50$ & 0.9 & 0.3 & 0.05 & 0.2 & 0.1 & 54.7 & $<0.1$ \\
\hline 92 & $<50$ & 0.6 & 0.2 & 0.05 & $<0.1$ & $<0.1$ & 47.7 & $<0.1$ \\
\hline 95.5 & $<50$ & 0.8 & 0.9 & $<0.05$ & $<0.1$ & $<0.1$ & 53.7 & $<0.1$ \\
\hline 99.4 & $<50$ & 0.9 & 1.1 & 0.08 & $<0.1$ & 0.1 & 57.1 & $<0.1$ \\
\hline 104.5 & 51 & 1.2 & 4.7 & 0.05 & 0.5 & 0.1 & 62.6 & $<0.1$ \\
\hline 116.5 & $<50$ & 1.7 & 1.1 & 0.06 & 0.3 & 0.2 & 64.8 & $<0.1$ \\
\hline 123.5 & 66 & 2.6 & 8.3 & 0.11 & 0.7 & 0.2 & 69 & $<0.1$ \\
\hline 140.5 & $<50$ & 2.1 & 1.7 & 0.13 & 0.3 & $<0.1$ & 51.6 & $<0.1$ \\
\hline 154.5 & 52 & 1.6 & 4.6 & $<0.05$ & 0.5 & 0.1 & 61.9 & $<0.1$ \\
\hline 160.3 & $<50$ & 5.3 & 0.8 & 0.08 & $<0.1$ & 0.2 & 19.8 & $<0.1$ \\
\hline
\end{tabular}




\section{Appendix 3A. Bulk elemental composition of solid-phase samples, site 1.-Continued}

[pct, percent; ppm, parts per million; ppm is equivalent to milligrams per kilogram]

\begin{tabular}{|c|c|c|c|c|c|c|c|}
\hline $\begin{array}{l}\text { Depth } \\
\text { (feet) }\end{array}$ & $\begin{array}{l}\text { Thorium } \\
\text { (ppm) }\end{array}$ & $\begin{array}{c}\text { Thallium } \\
\text { (ppm) }\end{array}$ & $\begin{array}{l}\text { Uranium } \\
\text { (ppm) }\end{array}$ & $\begin{array}{c}\text { Vanadium } \\
\text { (ppm) }\end{array}$ & $\begin{array}{c}\text { Tungsten } \\
\text { (ppm) }\end{array}$ & $\begin{array}{c}\text { Ytterbium } \\
\text { (ppm) }\end{array}$ & $\begin{array}{l}\text { Zinc } \\
\text { (ppm) }\end{array}$ \\
\hline 30.3 & 1.7 & 0.2 & 1.6 & 23 & 0.1 & 6.8 & 28 \\
\hline 31.3 & 2.2 & 0.2 & 1.5 & 28 & 0.2 & 9.2 & 24 \\
\hline 32 & 2.5 & 0.2 & 2.2 & 25 & 0.2 & 6.6 & 25 \\
\hline 33 & 1.6 & 0.2 & 1.9 & 19 & 0.1 & 5.7 & 21 \\
\hline 33.3 & 2.1 & 0.2 & 1.8 & 22 & 0.2 & 6.5 & 23 \\
\hline 34 & 1.7 & 0.2 & 1.9 & 18 & 0.2 & 5.9 & 34 \\
\hline 34.8 & 9.3 & 0.5 & 1.8 & 49 & 0.2 & 9.5 & 49 \\
\hline 42 & 3.9 & 0.4 & 2.5 & 38 & 0.3 & 12.1 & 45 \\
\hline 48 & 3.1 & 0.3 & 2.1 & 30 & 3.1 & 9.4 & 42 \\
\hline 49 & 2 & 0.3 & 1.9 & 28 & 0.5 & 9.4 & 35 \\
\hline 52.5 & 2.3 & 0.3 & 1.8 & 28 & 16.1 & 9.4 & 44 \\
\hline 57.8 & 5.3 & 0.7 & 2.8 & 82 & 0.5 & 27.7 & 134 \\
\hline 58 & 8 & 0.9 & 3.8 & 105 & 0.7 & 23.5 & 115 \\
\hline 58.5 & 9.2 & 1.4 & 4.5 & 138 & 0.8 & 25 & 146 \\
\hline 62.4 & 7 & 1 & 3 & 99 & 0.6 & 24.3 & 105 \\
\hline 67.1 & 7.2 & 0.8 & 3.3 & 78 & 32.9 & 16.4 & 58 \\
\hline 73 & $<0.2$ & 0.2 & 0.4 & 8 & 0.1 & 3 & 96 \\
\hline 75.4 & $<0.2$ & $<0.1$ & $<0.1$ & 4 & $<0.1$ & 4.1 & 9 \\
\hline 77 & 7.7 & 1.7 & 2.9 & 142 & 8.1 & 10.3 & 571 \\
\hline 80 & $<0.2$ & $<0.1$ & $<0.1$ & 5 & 0.3 & 4.6 & 21 \\
\hline 82 & $<0.2$ & $<0.1$ & $<0.1$ & 4 & $<0.1$ & 4 & 19 \\
\hline 83 & $<0.2$ & $<0.1$ & $<0.1$ & 3 & $<0.1$ & 3.2 & 21 \\
\hline 84 & $<0.2$ & $<0.1$ & 0.2 & 4 & $<0.1$ & 3.8 & 11 \\
\hline 85 & $<0.2$ & $<0.1$ & $<0.1$ & 3 & $<0.1$ & 4.6 & 9 \\
\hline 86 & $<0.2$ & $<0.1$ & $<0.1$ & 3 & $<0.1$ & 3.3 & 18 \\
\hline 87 & $<0.2$ & $<0.1$ & 0.2 & 4 & $<0.1$ & 4.2 & 12 \\
\hline 88 & $<0.2$ & $<0.1$ & $<0.1$ & 4 & $<0.1$ & 3.5 & 16 \\
\hline 92 & $<0.2$ & $<0.1$ & $<0.1$ & 3 & $<0.1$ & 2.6 & 15 \\
\hline 95.5 & $<0.2$ & $<0.1$ & 0.1 & 4 & 0.2 & 2.9 & 12 \\
\hline 99.4 & $<0.2$ & $<0.1$ & 0.2 & 4 & 0.2 & 3.1 & 16 \\
\hline 104.5 & 0.5 & $<0.1$ & 0.4 & 6 & 0.1 & 3.8 & 10 \\
\hline 116.5 & 0.3 & $<0.1$ & 0.1 & 4 & $<0.1$ & 6.4 & 8 \\
\hline 123.5 & 1 & $<0.1$ & 0.5 & 8 & 0.1 & 6.7 & 7 \\
\hline 140.5 & 0.5 & $<0.1$ & 0.2 & 5 & $<0.1$ & 6 & 19 \\
\hline 154.5 & 0.5 & $<0.1$ & 0.7 & 8 & $<0.1$ & 6.8 & 3 \\
\hline 160.3 & $<0.2$ & 0.2 & 0.2 & $<1$ & $<0.1$ & 0.1 & 47 \\
\hline
\end{tabular}




\section{Appendix 3B. Bulk elemental composition of solid-phase samples, site 2.}

$[<$, less than; pct, percent; ppm, parts per million; ppm is equivalent to milligrams per kilogram. Organic carbon concentrations were computed by subtracting carbonate carbon from total carbon concentrations; negative values for organic carbon are due to small amounts of measurement error.]

\begin{tabular}{|c|c|c|c|c|c|c|c|c|}
\hline $\begin{array}{l}\text { Depth } \\
\text { (feet) }\end{array}$ & $\begin{array}{c}\text { Organic } \\
\text { carbon } \\
\text { (pct) }\end{array}$ & $\begin{array}{c}\text { Total } \\
\text { carbon } \\
\text { (pct) }\end{array}$ & $\begin{array}{c}\mathrm{CO}_{2} \\
\text { (pct) }\end{array}$ & $\begin{array}{c}\text { Carbonate } \\
\text { carbon } \\
\text { (pct) }\end{array}$ & $\begin{array}{c}\text { Total } \\
\text { sulfur } \\
\text { (pct) }\end{array}$ & $\begin{array}{l}\text { Alum- } \\
\text { inum } \\
\text { (pct) }\end{array}$ & $\begin{array}{l}\text { Calcium } \\
\text { (pct) }\end{array}$ & $\begin{array}{l}\text { Iron } \\
\text { (pct) }\end{array}$ \\
\hline 29 & 0.8 & 6.38 & 20.45 & 5.58 & 0.38 & 3.76 & 11.4 & 1.87 \\
\hline 34 & 0.5 & 7.87 & 27.01 & 7.37 & 0.08 & 2.5 & 14.9 & 1.35 \\
\hline 35 & 0.47 & 8.33 & 28.81 & 7.86 & 0.09 & 2.07 & 15.55 & 1.17 \\
\hline 37 & 0.43 & 6.57 & 22.48 & 6.14 & 0.07 & 2.3 & 13.55 & 1.2 \\
\hline 39 & 0.59 & 4.81 & 15.45 & 4.22 & 0.06 & 3.56 & 9.14 & 1.92 \\
\hline 45 & 0.83 & 4.53 & 13.55 & 3.7 & 0.38 & 4.38 & 8.97 & 2.26 \\
\hline 51 & 0.43 & 5.41 & 18.23 & 4.98 & 0.34 & 3.14 & 12.13 & 1.59 \\
\hline 55 & 0.5 & 4.11 & 13.22 & 3.61 & 0.36 & 3.85 & 9.01 & 1.79 \\
\hline 58 & 0.44 & 4.37 & 14.4 & 3.93 & 0.34 & 4.6 & 9.66 & 2.39 \\
\hline 63 & 0.16 & 2.92 & 10.1 & 2.76 & 0.25 & 3.44 & 7.55 & 1.49 \\
\hline 69 & 0.24 & 4.97 & 17.33 & 4.73 & 0.28 & 3.11 & 11.98 & 1.96 \\
\hline 75 & 0.31 & 3.12 & 10.31 & 2.81 & 0.24 & 3.26 & 7.81 & 1.39 \\
\hline 77 & 0.05 & 3.01 & 10.83 & 2.96 & 0.34 & 3.19 & 8.38 & 1.97 \\
\hline 79 & 0.16 & 3 & 10.4 & 2.84 & 0.14 & 3.22 & 8.13 & 1.05 \\
\hline 85 & 0.78 & 4.04 & 11.95 & 3.26 & 0.36 & 5.77 & 8.06 & 3.26 \\
\hline 89 & 2.1 & 4.75 & 9.7 & 2.65 & 0.18 & 4.2 & 5.81 & 2.18 \\
\hline 90 & 0.19 & 6.89 & 24.54 & 6.7 & 0.1 & 2.14 & 11.84 & 1.89 \\
\hline 91 & 0.51 & 4.51 & 14.64 & 4 & 0.1 & 4.51 & 8.45 & 2.69 \\
\hline 93 & 0.75 & 3.91 & 11.56 & 3.16 & 0.06 & 5.2 & 7.81 & 3 \\
\hline 95 & 0.53 & 4.35 & 14.01 & 3.82 & 0.16 & 4.59 & 8.39 & 2.6 \\
\hline 99 & 0.44 & 3.57 & 11.47 & 3.13 & 0.13 & 4.96 & 7.21 & 3.32 \\
\hline 103 & 0.23 & 4.5 & 15.65 & 4.27 & 0.05 & 2.8 & 9.63 & 1.57 \\
\hline 106 & 0.19 & 5.84 & 20.7 & 5.65 & 0.12 & 4.14 & 10.95 & 2.54 \\
\hline 107 & -0.65 & 9.75 & 38.11 & 10.4 & $<0.05$ & 1.6 & 16.92 & 0.87 \\
\hline 108 & -1.52 & 10.7 & 44.78 & 12.22 & $<0.05$ & 0.41 & 20.25 & 0.27 \\
\hline 109 & -1.88 & 10.6 & 45.72 & 12.48 & $<0.05$ & 0.22 & 20.36 & 0.13 \\
\hline 111 & -0.38 & 11.2 & 42.44 & 11.58 & $<0.05$ & 0.35 & 21.17 & 0.28 \\
\hline 112 & -1.32 & 10 & 41.48 & 11.32 & $<0.05$ & 0.58 & 21.14 & 0.51 \\
\hline 114 & -0.38 & 10.7 & 40.6 & 11.08 & 0.07 & 0.18 & 31.14 & 0.18 \\
\hline 119 & 0.06 & 1.46 & 5.12 & 1.4 & $<0.05$ & 0.19 & 5.19 & 0.07 \\
\hline
\end{tabular}




\section{Appendix 3B. Bulk elemental composition of solid-phase samples, site 2.-Continued}

[<, less than; pct, percent; ppm, parts per million; ppm is equivalent to milligrams per kilogram]

\begin{tabular}{|c|c|c|c|c|c|c|c|c|}
\hline $\begin{array}{l}\text { Depth } \\
\text { (feet) }\end{array}$ & $\begin{array}{l}\text { Potas- } \\
\text { sium } \\
\text { (pct) }\end{array}$ & $\begin{array}{c}\text { Magnes- } \\
\text { ium } \\
\text { (pct) }\end{array}$ & $\begin{array}{c}\text { Sodium } \\
\text { (pct) }\end{array}$ & $\begin{array}{c}\text { Sulfur } \\
\text { (pct) }\end{array}$ & $\begin{array}{c}\text { Titanium } \\
\text { (pct) }\end{array}$ & $\begin{array}{c}\text { Arsenic } \\
\text { (ppm) }\end{array}$ & $\begin{array}{c}\text { Barium } \\
\text { (ppm) }\end{array}$ & $\begin{array}{l}\text { Silver } \\
\text { (ppm) }\end{array}$ \\
\hline 29 & 1.5 & 4.63 & 0.52 & 0.42 & 0.11 & 9 & 290 & $<1$ \\
\hline 34 & 0.99 & 6.28 & 0.49 & 0.1 & 0.08 & 4 & 203 & $<1$ \\
\hline 35 & 0.87 & 6.6 & 0.45 & 0.12 & 0.08 & 4 & 181 & $<1$ \\
\hline 37 & 0.91 & 4.98 & 0.59 & 0.09 & 0.08 & 5 & 229 & $<1$ \\
\hline 39 & 1.35 & 3.77 & 0.69 & 0.07 & 0.12 & 9 & 306 & $<1$ \\
\hline 45 & 1.69 & 3.54 & 0.76 & 0.44 & 0.13 & 8 & 348 & $<1$ \\
\hline 51 & 1.19 & 3.74 & 0.82 & 0.4 & 0.1 & 6 & 275 & $<1$ \\
\hline 55 & 1.47 & 3.18 & 1.01 & 0.42 & 0.1 & 6 & 360 & $<1$ \\
\hline 58 & 1.74 & 3.49 & 0.84 & 0.43 & 0.14 & 8 & 376 & $<1$ \\
\hline 63 & 1.25 & 2.09 & 1.14 & 0.28 & 0.12 & 4 & 375 & $<1$ \\
\hline 69 & 1.03 & 3.63 & 0.86 & 0.37 & 0.12 & 6 & 276 & $<1$ \\
\hline 75 & 1.18 & 1.92 & 1 & 0.27 & 0.09 & 4 & 337 & $<1$ \\
\hline 77 & 1.01 & 2.25 & 1 & 0.4 & 0.15 & 6 & 322 & $<1$ \\
\hline 79 & 1.11 & 1.9 & 1.07 & 0.17 & 0.07 & 3 & 343 & $<1$ \\
\hline 85 & 2.17 & 3.32 & 0.66 & 0.42 & 0.19 & 14 & 415 & $<1$ \\
\hline 89 & 1.52 & 3.14 & 0.77 & 0.19 & 0.15 & 9 & 399 & $<1$ \\
\hline 90 & 0.71 & 6.13 & 0.38 & 0.12 & 0.18 & 7 & 185 & $<1$ \\
\hline 91 & 1.65 & 4.05 & 0.32 & 0.12 & 0.15 & 8 & 297 & $<1$ \\
\hline 93 & 1.94 & 3.41 & 0.3 & 0.07 & 0.15 & 10 & 337 & $<1$ \\
\hline 95 & 1.69 & 3.77 & 0.29 & 0.19 & 0.13 & 9 & 315 & $<1$ \\
\hline 99 & 2.21 & 3.39 & 0.47 & 0.16 & 0.21 & 8 & 422 & $<1$ \\
\hline 103 & 1.19 & 3.55 & 0.39 & 0.06 & 0.1 & 5 & 251 & $<1$ \\
\hline 106 & 1.46 & 5.51 & 0.18 & 0.16 & 0.11 & 8 & 242 & $<1$ \\
\hline 107 & 0.42 & 9.73 & 0.07 & 0.04 & 0.06 & 11 & 120 & $<1$ \\
\hline 108 & 0.13 & 11.5 & 0.04 & 0.04 & 0.02 & 4 & 36 & $<1$ \\
\hline 109 & 0.08 & 11.55 & 0.04 & 0.04 & $<0.01$ & 2 & 11 & $<1$ \\
\hline 111 & 0.2 & 10.3 & 0.02 & 0.04 & 0.01 & $<1$ & 19 & $<1$ \\
\hline 112 & 0.32 & 10.77 & 0.02 & 0.05 & 0.03 & $<1$ & 26 & $<1$ \\
\hline 114 & 0.1 & 4.1 & 0.02 & 0.17 & $<0.01$ & $<1$ & 10 & $<1$ \\
\hline 119 & 0.06 & 0.12 & 0.04 & 0.02 & $<0.01$ & $<1$ & 40 & $<1$ \\
\hline
\end{tabular}




\section{Appendix 3B. Bulk elemental composition of solid-phase samples, site 2.-Continued}

[<, less than; pct, percent; ppm, parts per million; ppm is equivalent to milligrams per kilogram]

\begin{tabular}{|c|c|c|c|c|c|c|c|c|}
\hline $\begin{array}{l}\text { Depth } \\
\text { (feet) }\end{array}$ & $\begin{array}{c}\text { Beryllium } \\
\text { (ppm) }\end{array}$ & $\begin{array}{c}\text { Bismuth } \\
\text { (ppm) }\end{array}$ & $\begin{array}{c}\text { Cadmium } \\
\text { (ppm) }\end{array}$ & $\begin{array}{c}\text { Cerium } \\
\text { (ppm) }\end{array}$ & $\begin{array}{l}\text { Cobalt } \\
\text { (ppm) }\end{array}$ & $\begin{array}{c}\text { Chromium } \\
\text { (ppm) }\end{array}$ & $\begin{array}{l}\text { Cesium } \\
\text { (ppm) }\end{array}$ & $\begin{array}{c}\text { Copper } \\
(\mathbf{p p m})\end{array}$ \\
\hline 29 & 1.4 & 0.11 & 0.4 & 37.4 & 8.3 & 28 & 3.45 & 19.4 \\
\hline 34 & 0.9 & 0.06 & 0.2 & 26.8 & 5.3 & 17 & 1.66 & 16.5 \\
\hline 35 & 0.6 & 0.09 & 0.2 & 24.2 & 5.2 & 17 & 1.16 & 16.4 \\
\hline 37 & 0.7 & 0.05 & 0.1 & 19.7 & 3.4 & 16 & 1.04 & 11.5 \\
\hline 39 & 1.2 & 0.08 & 0.2 & 35.6 & 7.4 & 24 & 2.38 & 16.3 \\
\hline 45 & 1.3 & 0.08 & 0.1 & 39.4 & 9.3 & 32 & 3.13 & 19 \\
\hline 51 & 1 & 0.06 & 0.1 & 26.2 & 6 & 21 & 1.54 & 15.7 \\
\hline 55 & 1.2 & 0.07 & 0.1 & 28 & 6.6 & 25 & 1.76 & 17.2 \\
\hline 58 & 1.6 & 0.1 & 0.1 & 38.5 & 9.5 & 37 & 3.1 & 19 \\
\hline 63 & 0.9 & 0.06 & 0.1 & 25.5 & 5 & 19 & 0.89 & 10.3 \\
\hline 69 & 0.8 & 0.06 & 0.1 & 26.7 & 7 & 29 & 1.03 & 11.3 \\
\hline 75 & 0.9 & 0.06 & 0.1 & 22.1 & 4.7 & 17 & 0.99 & 11.8 \\
\hline 77 & 0.9 & 0.07 & 0.2 & 26.5 & 5.6 & 25 & 0.7 & 11.5 \\
\hline 79 & 0.8 & $<0.04$ & $<0.1$ & 18.2 & 3.8 & 13 & 0.73 & 7.7 \\
\hline 85 & 1.8 & 0.11 & 0.1 & 56.5 & 12.9 & 45 & 5.03 & 26.7 \\
\hline 89 & 1.2 & 0.11 & 0.3 & 47 & 8.1 & 30 & 2.62 & 16.7 \\
\hline 90 & 0.7 & 0.08 & 0.2 & 28.4 & 6.7 & 17 & 1.22 & 12.4 \\
\hline 91 & 1.8 & 0.1 & 0.3 & 47.3 & 11.3 & 37 & 4.36 & 24.7 \\
\hline 93 & 1.9 & 0.1 & 0.4 & 55.2 & 11.4 & 43 & 5.1 & 23.1 \\
\hline 95 & 1.7 & 0.09 & 0.3 & 49.1 & 10.7 & 36 & 4.48 & 19.2 \\
\hline 99 & 1.5 & 0.33 & 0.3 & 52.7 & 13 & 46 & 3.97 & 21.8 \\
\hline 103 & 1 & 0.08 & 0.3 & 36.5 & 6.1 & 22 & 1.96 & 14.7 \\
\hline 106 & 1.4 & 0.13 & 0.3 & 50.3 & 10.1 & 33 & 3.95 & 17.8 \\
\hline 107 & 0.6 & 0.12 & $<0.1$ & 31.4 & 5.3 & 16 & 1.54 & 9.1 \\
\hline 108 & 0.2 & 0.08 & $<0.1$ & 12.4 & 2 & 8 & 0.36 & 6.1 \\
\hline 109 & 0.2 & $<0.04$ & $<0.1$ & 8.96 & 0.8 & 6 & 0.17 & 6.3 \\
\hline 111 & 0.2 & $<0.04$ & $<0.1$ & 10.5 & 0.8 & 7 & 0.34 & 6 \\
\hline 112 & 0.3 & $<0.04$ & $<0.1$ & 10.7 & 0.8 & 18 & 0.61 & 6.8 \\
\hline 114 & 0.1 & $<0.04$ & $<0.1$ & 12.6 & 1.8 & 8 & 0.26 & 9.5 \\
\hline 119 & $<0.1$ & $<0.04$ & $<0.1$ & 3.26 & 0.3 & 3 & 0.11 & 4.3 \\
\hline
\end{tabular}




\section{Appendix 3B. Bulk elemental composition of solid-phase samples, site 2.-Continued}

[<, less than; pct, percent; ppm, parts per million; ppm is equivalent to milligrams per kilogram]

\begin{tabular}{|c|c|c|c|c|c|c|c|c|}
\hline $\begin{array}{l}\text { Depth } \\
\text { (feet) }\end{array}$ & $\begin{array}{c}\text { Gallium } \\
\text { (ppm) }\end{array}$ & $\begin{array}{c}\text { Indium } \\
\text { (ppm) }\end{array}$ & $\begin{array}{l}\text { Lanth- } \\
\text { anum } \\
\text { (ppm) }\end{array}$ & $\begin{array}{c}\text { Lithium, } \\
\text { (ppm) }\end{array}$ & $\begin{array}{c}\text { Man- } \\
\text { ganese } \\
\text { (ppm) }\end{array}$ & $\begin{array}{l}\text { Molyb- } \\
\text { denum } \\
\text { (ppm) }\end{array}$ & $\begin{array}{c}\text { Niobium } \\
\text { (ppm) }\end{array}$ & $\begin{array}{r}\text { Nicke } \\
\text { (ppm) }\end{array}$ \\
\hline 29 & 8.8 & 0.03 & 19 & 22 & 384 & 7.13 & 4.8 & 20.5 \\
\hline 34 & 5.79 & 0.02 & 13.4 & 15 & 358 & 2.8 & 3.3 & 9.1 \\
\hline 35 & 4.97 & $<0.02$ & 12.1 & 11 & 326 & 3.2 & 2.3 & 12.4 \\
\hline 37 & 4.73 & $<0.02$ & 9.8 & 11 & 330 & 3.32 & 2.6 & 9 \\
\hline 39 & 8.28 & 0.03 & 17.9 & 19 & 414 & 3.9 & 4.3 & 15.3 \\
\hline 45 & 10.1 & 0.04 & 19.4 & 25 & 479 & 5.73 & 5.2 & 20.3 \\
\hline 51 & 6.78 & 0.02 & 13.2 & 13 & 479 & 5.7 & 3.5 & 11.7 \\
\hline 55 & 8.01 & 0.03 & 14.1 & 15 & 421 & 4.63 & 3.7 & 14.9 \\
\hline 58 & 10.3 & 0.04 & 19.7 & 24 & 513 & 4.92 & 5.1 & 22 \\
\hline 63 & 7.17 & 0.02 & 12.6 & 8 & 409 & 2.38 & 3.5 & 10 \\
\hline 69 & 6.73 & 0.02 & 13.2 & 12 & 581 & 3.08 & 3.4 & 12.7 \\
\hline 75 & 6.86 & 0.02 & 11.2 & 9 & 381 & 2.94 & 2.8 & 10.9 \\
\hline 77 & 6.69 & 0.03 & 12.4 & 7 & 531 & 1.97 & 4.9 & 10.9 \\
\hline 79 & 6.34 & $<0.02$ & 9.5 & 7 & 332 & 1.62 & 2 & 8.7 \\
\hline 85 & 13.2 & 0.05 & 27.9 & 35 & 579 & 4.45 & 7.3 & 32.5 \\
\hline 89 & 8.82 & 0.04 & 22.9 & 20 & 490 & 3.71 & 5.4 & 19.7 \\
\hline 90 & 5.48 & 0.03 & 12.9 & 12 & 635 & 1.97 & 3.7 & 10 \\
\hline 91 & 11 & 0.05 & 22.9 & 33 & 720 & 2.21 & 5.7 & 23.4 \\
\hline 93 & 12.2 & 0.05 & 27.1 & 39 & 648 & 2.9 & 6.3 & 26.6 \\
\hline 95 & 10.5 & 0.05 & 23.8 & 36 & 590 & 2.82 & 5.5 & 21.7 \\
\hline 99 & 11.7 & 0.06 & 26.2 & 41 & 630 & 2.63 & 7.1 & 26.6 \\
\hline 103 & 6.13 & 0.03 & 18.2 & 17 & 559 & 1.42 & 3.7 & 13.7 \\
\hline 106 & 9.65 & 0.04 & 23.3 & 35 & 842 & 2.15 & 4.6 & 19.3 \\
\hline 107 & 3.85 & $<0.02$ & 17 & 15 & 438 & 0.89 & 3.1 & 9.8 \\
\hline 108 & 0.98 & $<0.02$ & 9 & 4 & 356 & 0.27 & 1.2 & 1.3 \\
\hline 109 & 0.54 & $<0.02$ & 7.2 & 3 & 205 & 0.08 & 0.7 & 2.1 \\
\hline 111 & 0.83 & $<0.02$ & 7.9 & 4 & 238 & 0.27 & 0.8 & 1.6 \\
\hline 112 & 1.38 & $<0.02$ & 7.9 & 5 & 192 & 0.58 & 1.3 & $<0.5$ \\
\hline 114 & 0.52 & $<0.02$ & 12.9 & 2 & 135 & 0.08 & 0.6 & 0.8 \\
\hline 119 & 0.31 & $<0.02$ & 2.3 & 7 & 22 & 0.16 & 0.2 & $<0.5$ \\
\hline
\end{tabular}




\section{Appendix 3B. Bulk elemental composition of solid-phase samples, site 2.-Continued}

[<, less than; pct, percent; ppm, parts per million; ppm is equivalent to milligrams per kilogram]

\begin{tabular}{|c|c|c|c|c|c|c|c|c|}
\hline $\begin{array}{l}\text { Depth, } \\
\text { (feet) }\end{array}$ & $\begin{array}{c}\text { Phosph- } \\
\text { orus } \\
\text { (ppm) }\end{array}$ & $\begin{array}{l}\text { Lead } \\
\text { (ppm) }\end{array}$ & $\begin{array}{l}\text { Rubidium } \\
\text { (ppm) }\end{array}$ & $\begin{array}{c}\text { Antimon, } \\
\text { (ppm) }\end{array}$ & $\begin{array}{l}\text { Scandium } \\
\text { (ppm) }\end{array}$ & $\underset{\text { (ppm) }}{\text { Tin }}$ & $\begin{array}{l}\text { Strontium } \\
\text { (ppm) }\end{array}$ & $\begin{array}{c}\text { Tellurium } \\
\text { (ppm) }\end{array}$ \\
\hline 29 & 354 & 27.8 & 69.4 & 0.7 & 7 & 1.1 & 296.1 & $<0.1$ \\
\hline 34 & 277 & 9 & 40.5 & 0.34 & 4.5 & 0.7 & 267.7 & $<0.1$ \\
\hline 35 & 215 & 6.9 & 34.5 & 0.32 & 4.1 & 0.5 & 212.4 & $<0.1$ \\
\hline 37 & 240 & 7.2 & 32.1 & 0.32 & 3.5 & 1.3 & 243.6 & $<0.1$ \\
\hline 39 & 364 & 11.8 & 56.3 & 0.45 & 6.2 & 1 & 328.7 & $<0.1$ \\
\hline 45 & 427 & 12.6 & 72.1 & 0.41 & 8 & 1.2 & 364.3 & 0.1 \\
\hline 51 & 302 & 9.6 & 44.5 & 0.34 & 5.3 & 0.7 & 270.4 & $<0.1$ \\
\hline 55 & 390 & 11.4 & 51.1 & 0.33 & 5.8 & 0.8 & 304.9 & $<0.1$ \\
\hline 58 & 454 & 12.5 & 72.3 & 0.39 & 8 & 1.2 & 364.3 & $<0.1$ \\
\hline 63 & 326 & 10 & 39.7 & 0.25 & 4.8 & 0.6 & 266.7 & $<0.1$ \\
\hline 69 & 351 & 8 & 36.8 & 0.26 & 6 & 0.7 & 244.9 & $<0.1$ \\
\hline 75 & 269 & 9.6 & 39.5 & 0.27 & 4.4 & 0.6 & 258.4 & $<0.1$ \\
\hline 77 & 350 & 8.8 & 31.4 & 0.24 & 6.2 & 0.8 & 257.7 & $<0.1$ \\
\hline 79 & 221 & 8.5 & 34.7 & 0.13 & 3.6 & 0.4 & 265.7 & $<0.1$ \\
\hline 85 & 563 & 16.1 & 98 & 0.51 & 10.9 & 1.8 & 318.8 & $<0.1$ \\
\hline 89 & 481 & 14.5 & 61.9 & 0.37 & 7.1 & 1.1 & 300.7 & $<0.1$ \\
\hline 90 & 345 & 10.6 & 31.4 & 0.4 & 5.6 & 0.7 & 136.6 & $<0.1$ \\
\hline 91 & 380 & 16.1 & 79.9 & 0.87 & 9.2 & 1.6 & 160.2 & $<0.1$ \\
\hline 93 & 418 & 16.8 & 92.8 & 0.65 & 9.6 & 1.7 & 167.7 & $<0.1$ \\
\hline 95 & 381 & 15.5 & 82.8 & 0.66 & 8.7 & 1.5 & 153.9 & $<0.1$ \\
\hline 99 & 387 & 16.2 & 89.2 & 0.59 & 10.4 & 1.8 & 145.9 & $<0.1$ \\
\hline 103 & 384 & 10.6 & 47 & 0.42 & 5.1 & 0.8 & 145.9 & $<0.1$ \\
\hline 106 & 317 & 15.8 & 71.6 & 0.51 & 7.7 & 1.3 & 152.8 & $<0.1$ \\
\hline 107 & 110 & 10.1 & 27.5 & 0.38 & 3.5 & 0.6 & 101.4 & $<0.1$ \\
\hline 108 & 58 & 5.6 & 7 & 0.17 & 1.3 & 0.2 & 64.2 & $<0.1$ \\
\hline 109 & $<50$ & 2.7 & 3.7 & 0.11 & 0.9 & 0.1 & 56 & $<0.1$ \\
\hline 111 & 55 & 2.7 & 7.6 & 0.09 & 0.9 & 0.2 & 62.8 & $<0.1$ \\
\hline 112 & 59 & 4.1 & 12.4 & 0.15 & 1.5 & 0.2 & 76.4 & $<0.1$ \\
\hline 114 & 59 & 4.5 & 4.3 & 0.09 & 1.4 & $<0.1$ & 121.7 & $<0.1$ \\
\hline 119 & $<50$ & 1.1 & 2 & 0.07 & 0.2 & 0.1 & 58 & $<0.1$ \\
\hline
\end{tabular}




\section{Appendix 3B. Bulk elemental composition of solid-phase samples, site 2.-Continued}

$[<$, less than; pct, percent; ppm, parts per million; ppm is equivalent to milligrams per kilogram]

\begin{tabular}{|c|c|c|c|c|c|c|c|}
\hline $\begin{array}{l}\text { Depth, } \\
\text { (feet) }\end{array}$ & $\begin{array}{c}\text { Thorium } \\
\text { (ppm) }\end{array}$ & $\begin{array}{c}\text { Thallium } \\
\text { (ppm) }\end{array}$ & $\begin{array}{c}\text { Uranium } \\
\text { (ppm) }\end{array}$ & $\begin{array}{c}\text { Vanadium } \\
(\mathrm{ppm})\end{array}$ & $\begin{array}{c}\text { Tungsten } \\
\text { (ppm) }\end{array}$ & $\begin{array}{c}\text { Ytterbium } \\
\text { (ppm) }\end{array}$ & $\begin{array}{c}\text { Zinc } \\
\text { (ppm) }\end{array}$ \\
\hline 29 & 5.6 & 0.8 & 4.4 & 71 & 0.5 & 13.3 & 54 \\
\hline 34 & 3.6 & 0.4 & 2.4 & 35 & 0.4 & 9.8 & 34 \\
\hline 35 & 3.6 & 0.3 & 2.6 & 55 & 0.2 & 8.3 & 29 \\
\hline 37 & 2.4 & 0.2 & 2 & 31 & 0.2 & 8.7 & 37 \\
\hline 39 & 5.1 & 0.6 & 2.7 & 51 & 0.4 & 13.3 & 48 \\
\hline 45 & 6 & 0.6 & 3.3 & 61 & 0.5 & 14.4 & 54 \\
\hline 51 & 3.6 & 0.4 & 3 & 41 & 0.3 & 12.4 & 39 \\
\hline 55 & 4.2 & 0.5 & 2.6 & 44 & 0.5 & 11.6 & 42 \\
\hline 58 & 6 & 0.6 & 3 & 64 & 0.5 & 14.4 & 50 \\
\hline 63 & 3.1 & 0.3 & 1.7 & 34 & 0.3 & 11 & 42 \\
\hline 69 & 3.5 & 0.3 & 2 & 46 & 0.3 & 12.6 & 40 \\
\hline 75 & 2.8 & 0.3 & 1.8 & 33 & 0.3 & 9.3 & 40 \\
\hline 77 & 2.7 & 0.3 & 1.4 & 43 & 0.2 & 14.6 & 83 \\
\hline 79 & 2.1 & 0.3 & 1.2 & 26 & 0.2 & 7.6 & 32 \\
\hline 85 & 9.3 & 0.8 & 3.7 & 89 & 0.7 & 17.8 & 67 \\
\hline 89 & 7.2 & 0.6 & 2.8 & 59 & 0.5 & 16.6 & 61 \\
\hline 90 & 3.5 & 0.3 & 1.8 & 49 & 0.5 & 13 & 35 \\
\hline 91 & 7.6 & 0.8 & 3.1 & 86 & 0.7 & 15.2 & 73 \\
\hline 93 & 8.8 & 0.8 & 3.3 & 95 & 0.7 & 15.8 & 77 \\
\hline 95 & 7.8 & 0.7 & 2.8 & 82 & 0.6 & 14.6 & 70 \\
\hline 99 & 8.2 & 0.7 & 2.6 & 88 & 2.1 & 13.8 & 73 \\
\hline 103 & 5.5 & 0.4 & 2.3 & 46 & 0.3 & 12 & 43 \\
\hline 106 & 7.2 & 0.6 & 2.8 & 72 & 0.5 & 17 & 59 \\
\hline 107 & 3.9 & 0.2 & 1.1 & 33 & 0.4 & 13.4 & 44 \\
\hline 108 & 1.4 & $<0.1$ & 0.4 & 13 & 0.2 & 9.3 & 22 \\
\hline 109 & 1 & $<0.1$ & 0.2 & 10 & 0.1 & 8.2 & 11 \\
\hline 111 & 1.1 & $<0.1$ & 0.6 & 9 & 0.2 & 8.7 & 11 \\
\hline 112 & 1.8 & $<0.1$ & 1.2 & 17 & 0.2 & 8.4 & 10 \\
\hline 114 & 1.1 & $<0.1$ & 1.1 & 15 & $<0.1$ & 12.1 & 23 \\
\hline 119 & 0.2 & $<0.1$ & 0.2 & $<1$ & $<0.1$ & 1.7 & 17 \\
\hline
\end{tabular}




\section{Appendix 4. Mineralogical description of seven solid-phase samples.}

[\%, percent]

\begin{tabular}{cc}
\hline Composition & \multicolumn{1}{c}{\begin{tabular}{c} 
Hoscription $1 \mathrm{~A}$ \\
\hline
\end{tabular}} \\
\hline $\begin{array}{c}\text { S4\% Carbonate } 1, \text { glacial deposits at } 33 \text { feet } \\
\text { fragments }\end{array}$ & $\begin{array}{c}\text { Includes rounded micritic calcite, dolomitized micritic calcite, and dolomite clasts. In dolomite clasts, } \\
\text { crystals are rhombic and range from fine- to coarse-grained. Carbonate clasts are commonly fossiliferous. } \\
\text { Barite is commonly associated with dolomite. Carbonate grains host pyrite with arsenic concentration up } \\
\text { to } 2.56 \text { weight percent. }\end{array}$
\end{tabular}

8\% Feldspar grains

$12 \%$ Quartz grains

13\% Igneous-rock fragments

2\% Sedimentary-rock fragments
Mainly plagioclase(?); some potassium feldspar. Some feldspar partially altered to sericitic clays.

Many grains with sweeping extinction, possibly metamorphic origin. Many grains were intensely cracked, interfering with interference figures.

Granite (quartz, feldspar, pyroxene, biotite altered to chlorite); rare fragments with myrmekitic texture. Several highly altered volcanic clasts with oriented plagioclase laths.

Shaly illitic clay-rich clasts with iron oxide stain. Framboidal pyrite common.

Pyroxene as liberated large grains. Accessory ilmenite, rutile, chalcopyrite, zircon

\section{Horizon 1B}

Site 1, glacial deposits at 48 feet

$57 \%$ Carbonate fragments

Includes rounded micritic calcite, dolomitized micritic calcite, and dolomite clasts. In dolomite fragments, crystals are rhombic and range from fine- to coarse-grained. Carbonate fragments host abundant fossils, some altered to silica. Barite is commonly associated with dolomite.

2\% Feldspar grains $\quad$ Mainly plagioclase(?). Partially alteration to sericitic clays.

17\% Quartz grains

$12 \%$ Igneous-rock fragments

$12 \%$ Sedimentary-rock fragments
Mainly granite (quartz, feldspar, pyroxene, biotite altered to chlorite). Rare fragments with myrmekitic texture.

Accessory monazite, rutile, framboidal pyrite, chalcopyrite, zircon, magnetite(?) altered to hematite(?). Fine- to medium-grained carbonate matrix common around all grain types.

Many grains with sweeping extinction, possibly metamorphic origin. Many grains were intensely cracked, interfering with interference figures.

6\% Shaly illitic clay-rich fragments with iron-oxide stain. Framboidal pyrite common.

6\% Siltstone (?), chert grains. Iron-oxide-stained clay-rich layers are associated with the siltstone. One fragment showed a lithologic boundary between the two rock types. Arsenic-bearing pyrite and nickelarsenic sulfide hosted in siltstone. Arsenic detected at concentrations (in pyrite within siltstone?) up to 0.44 weight percent. 


\section{Appendix 4. Mineralogical description of seven solid-phase samples.- Continued}

\begin{tabular}{ll}
\hline \multicolumn{1}{c}{ Site 1, unconsolidated bedrock zone at 77 feet } \\
\hline $\begin{array}{l}47 \% \text { Carbonate } \\
\text { fragments }\end{array}$ & $\begin{array}{c}\text { Dolomite clasts with occasional fossil fragments. Minor rounded micritic calcite clasts. Dolomite rhombs are } \\
\text { etched and corroded and float in the clay matrix. }\end{array}$ \\
$\begin{array}{l}\text { Iron-oxide-stained illitic (?) clay coats etched dolomite rhombs. Nickel-arsenic sulfide minerals abundant in } \\
\text { clay matrix. Arsenic detected at concentrations up to } 4.3 \text { weight percent in nickel-arsenic sulfide minerals. }\end{array}$ \\
$\begin{array}{c}7 \% \text { Igneous-rock } \\
\text { fragments }\end{array}$ \\
\hline
\end{tabular}

\begin{tabular}{ll}
\hline & \multicolumn{1}{c}{$\begin{array}{c}\text { Horizon 1C } \\
\text { Site 1, carbonate bedrock at } 86 \text { feet }\end{array}$} \\
\hline $\begin{array}{l}100 \% \text { Carbonate } \\
\text { fragments }\end{array}$ & $\begin{array}{l}\text { Dolomite. } \\
\text { Others: Iron oxide pseudomorphs after coarsely crystalline pyrite (?). Framboidal pyrite, barite, sylvite, } \\
\text { occasional detrital quartz grains. }\end{array}$ \\
\hline
\end{tabular}

\section{Site 2 glacial deposits at 34 feet}

$75 \%$ Carbonate fragments

2\% Feldspar grains

6\% Igneous-rock fragments

$13 \%$ Sedimentary-rock fragments
4\% Quartz grains

Includes rounded micritic calcite, dolomitized micritic calcite, and dolomite clasts. Dolomite crystals are rhombic, fine- to coarse-grained. Micritic carbonate clasts host silt-size quartz and feldspar grains. Carbonate clasts host fossils, some altered to silica. Barite is commonly associated with dolomite. Framboidal pyrite.

Mainly plagioclase (?). Partial alteration to sericitic clays.

Many grains with sweeping extinction, possibly metamorphic. Many grains were intensely cracked, interfering with interference figures.

Granite (coarse-grained quartz, feldspar, ferromagnesium minerals, mica). Some fine-grained altered volcanic fragments with oriented plagioclase crystals.

2\% Shaly illitic clay-rich fragments with iron-oxide stain. Framboidal pyrite common.

11\% Siltstone (?) and chert (?). Siltstone clasts have quartz, feldspar, mica, and carbonate and iron-oxide cement. Chert is partially replaced by dolomite.

\section{Horizon 2B}

Site 2, glacial deposits at 77 feet

$32 \%$ Carbonate fragments

Includes rounded micritic calcite, dolomitized micritic calcite, and dolomite clasts. Dolomite crystals are rhombic, fine- to coarse-grained. Micritic carbonate clasts host silt-size quartz and feldspar grains. Carbonate fragments host fossils, some altered to silica. Barite is commonly associated with dolomite.

$14 \%$ Feldspar grains

Plagioclase and potassium feldspar. Some feldspars partially altered to sericitic clays.

27\% Quartz grains

Many grains with sweeping extinction, possibly metamorphic. Many grains were intensely cracked, interfering with interference figures.

21\% Igneous-rock fragments

Granite (coarse-grained quartz, feldspar, ferromagnesium minerals, mica). Some fine-grained altered volcanic fragments with oriented plagioclase crystals.

$1 \%$ Sedimentary-rock fragments

Shaly illitic clay-rich fragments with iron-oxide stain. Chert fragments with abundant framboidal pyrite. Rare phosphatic (?) shell fragments. Framboidal pyrite has replaced shell fragment(s); framboids in turn are coated by second-generation coarsely crystalline pyrite that contains up to 1.3 weight percent arsenic. 


\section{Appendix 4. Mineralogical description of seven solid-phase samples.- Continued}

\begin{tabular}{ll}
\hline & $\begin{array}{c}\text { Horizon 2C } \\
\text { Site 2, glacial deposits at 90 feet }\end{array}$ \\
\hline $\begin{array}{l}\text { 95\% Carbonate/ } \\
\text { Sedimentary-rock } \\
\text { fragments }\end{array}$ & $\begin{array}{c}\text { Rounded clasts are composed of poorly sorted micritic carbonate and silt- to pebble-size feldspar, quartz } \\
\text { grains, and ferromagnesium mineral fragments. The clasts also host abundant organic material, wherein } \\
\text { cellular material is commonly replaced by iron sulfides (pyrite?). Some carbonate fragments host fossil } \\
\text { fragments. Framboidal pyrite is common. }\end{array}$ \\
& Medium- to coarse-size grains in carbonate. \\
& $\begin{array}{l}\text { Massive pyrite replaces large fragments of cellular organic material. Arsenic detected at concentrations up to } \\
0.26 \text { weight percent. }\end{array}$ \\
\hline
\end{tabular}




\section{Appendix 5A. Results of inverse mass-balance modeling. Initial water is ground-water sample from horizon $1 A$; final water is sample from horizon 1B.}

[All data are in moles; positive values indicate mineral dissolution, negative values indicate mineral precipitation; --, constituent not used in model calculations]

\begin{tabular}{|c|c|c|c|c|}
\hline Chemical constituent & Model 1 & Model 2 & Model 3 & Model 4 \\
\hline Dolomite & -- & -- & -- & -- \\
\hline Calcite & -- & -- & $-2.795 \times 10^{-4}$ & $-2.793 \times 10^{-4}$ \\
\hline Pyrite & $-3.145 \times 10^{-4}$ & $-3.145 \times 10^{-4}$ & $-3.145 \times 10^{-4}$ & $-3.145 \times 10^{-4}$ \\
\hline Goethite & $3.369 \times 10^{-4}$ & $3.369 \times 10^{-4}$ & $3.369 \times 10^{-4}$ & $3.369 \times 10^{-4}$ \\
\hline $\mathrm{CH}_{2} \mathrm{O}$ & $1.180 \times 10^{-3}$ & $1.180 \times 10^{-3}$ & $1.180 \times 10^{-3}$ & $1.180 \times 10^{-3}$ \\
\hline $\mathrm{CO}_{2}$ (gas) & $3.558 \times 10^{-4}$ & $3.558 \times 10^{-4}$ & -- & -- \\
\hline $\mathrm{O}_{2}$ (gas) & -- & -- & -- & -- \\
\hline Chalcedony & -- & -- & -- & -- \\
\hline K-feldpsar & -- & -- & -- & -- \\
\hline Illite & -- & -- & -- & -- \\
\hline Kaolinite & -- & -- & -- & -- \\
\hline $\mathrm{CaX} 2$ & -- & $3.584 \times 10^{-5}$ & -- & $3.584 \times 10^{-5}$ \\
\hline $\operatorname{MgX} 2$ & -- & -- & -- & -- \\
\hline $\mathrm{NaX}$ & $6.307 \times 10^{-5}$ & -- & $6.307 \times 10^{-5}$ & -- \\
\hline $\mathrm{KX}$ & $-6.307 \times 10^{-5}$ & $-7.168 \times 10^{-5}$ & $-6.307 \times 10^{-5}$ & $-7.168 \times 10^{-5}$ \\
\hline Halite & $-7.462 \times 10^{-5}$ & $-5.648 \times 10^{-5}$ & $-7.462 \times 10^{-5}$ & $-5.648 \times 10^{-5}$ \\
\hline
\end{tabular}




\section{Appendix 5B. Results of inverse mass-balance modeling. Initial water is ground-water sample from horizon 2A; final water is sample from horizon $2 B$.}

[All data are in moles; positive values indicate mineral dissolution, negative values indicate mineral precipitation; --, constituent not used in model calculations]

\begin{tabular}{llll}
\hline Chemical constituent & Model 1 & Model 2 & Model 3 \\
\hline Dolomite & -- & -- & -- \\
Calcite & $-4.978 \times 10^{-4}$ & $-4.546 \times 10^{-4}$ & $-4.782 \times 10^{-4}$ \\
Pyrite & $-1.975 \times 10^{-4}$ & $-1.975 \times 10^{-4}$ & $-1.975 \times 10^{-4}$ \\
Goethite & $2.217 \times 10^{-4}$ & $2.217 \times 10^{-4}$ & $2.217 \times 10^{-4}$ \\
$\mathrm{CH}_{2} \mathrm{O}$ & $7.485 \times 10^{-4}$ & $7.485 \times 10^{-4}$ & $7.485 \times 10^{-4}$ \\
$\mathrm{CO}_{2}$ (gas) & -- & -- & -- \\
$\mathrm{O}_{2}$ (gas) & -- & -- & -- \\
Chalcedony & $-5.120 \times 10^{-5}$ & -- & $-5.120 \times 10^{-5}$ \\
K-feldpsar & -- & -- & $2.558 \times 10^{-5}$ \\
Illite & $4.263 \times 10^{-5}$ & -- & -- \\
Kaolinite & $-4.903 \times 10^{-5}$ & -- & $1.279 \times 10^{-5}$ \\
CaX2 & $5.113 \times 10^{-4}$ & $4.681 \times 10^{-4}$ & $4.917 \times 10^{-4}$ \\
MgX2 & $-8.727 \times 10^{-4}$ & $-8.424 \times 10^{-4}$ & $-8.531 \times 10^{-4}$ \\
NaX & $7.229 \times 10^{-4}$ & $7.229 \times 10^{-4}$ & $7.229 \times 10^{-4}$ \\
KX & -- & $2.558 \times 10^{-5}$ & -- \\
Halite & $-1.637 \times 10^{-3}$ & -- & $-1.637 \times 10^{-3}$ \\
\hline
\end{tabular}




\section{Appendix 5C. Results of inverse mass-balance modeling. Initial water is ground-water sample from horizon 2B; final water is sample from horizon 2C.}

[All data are in moles; positive values indicate mineral dissolution, negative values indicate mineral precipitation; --, constituent not used in model calculations]

\begin{tabular}{llll}
\hline Chemical constituent & Model 1 & Model 2 & Model 3 \\
\hline Dolomite & -- & -- & -- \\
Calcite & $-1.546 \times 10^{-3}$ & $-1.546 \times 10^{-3}$ & $-5.619 \times 10^{-4}$ \\
Pyrite & $-1.768 \times 10^{-4}$ & $-1.768 \times 10^{-4}$ & $-1.768 \times 10^{-4}$ \\
Goethite & $1.336 \times 10^{-4}$ & $1.336 \times 10^{-4}$ & $1.336 \times 10^{-4}$ \\
$\mathrm{CH}_{2} \mathrm{O}$ & $6.512 \times 10^{-4}$ & $6.512 \times 10^{-4}$ & $6.512 \times 10^{-4}$ \\
$\mathrm{CO}_{2}$ (gas) & -- & -- & $-9.838 \times 10^{-4}$ \\
$\mathrm{O}_{2}$ (gas) & -- & -- & -- \\
Chalcedony & $-2.263 \times 10^{-3}$ & $-4.263 \times 10^{-3}$ & $-1.166 \times 10^{-4}$ \\
$\mathrm{~K}$-feldpsar & -- & $1.968 \times 10^{-3}$ & -- \\
Kaolinite & $-2.057 \times 10^{-3}$ & $-9.838 \times 10^{-4}$ & -- \\
Illite & $1.789 \times 10^{-3}$ & -- & -- \\
CaX2 & $1.234 \times 10^{-3}$ & $1.234 \times 10^{-3}$ & $2.497 \times 10^{-4}$ \\
MgX2 & $-7.354 \times 10^{-4}$ & -- & $-2.882 \times 10^{-4}$ \\
NaX & $1.410 \times 10^{-4}$ & $1.410 \times 10^{-4}$ & $1.410 \times 10^{-4}$ \\
KX & $-1.137 \times 10^{-3}$ & $-2.032 \times 10^{-3}$ & $-6.398 \times 10^{-5}$ \\
Halite & $-1.411 \times 10^{-4}$ & $-1.411 \times 10^{-4}$ & $-1.411 \times 10^{-4}$ \\
\hline
\end{tabular}




\section{Appendix 5D. Results of inverse mass-balance modeling. Initial water is hypothetical rain water; final water is sample from horizon $1 \mathrm{~A}$.}

[All data are in moles; positive values indicate mineral dissolution, negative values indicate mineral precipitation; --, constituent not used in model calculations]

\begin{tabular}{lll}
\hline Chemical constituent & Model 1 & Model 2 \\
\hline Dolomite & $3.256 \times 10^{-3}$ & $3.256 \times 10^{-3}$ \\
Calcite & -- & -- \\
Pyrite & $1.292 \times 10^{-3}$ & $1.292 \times 10^{-3}$ \\
Goethite & $-1.264 \times 10^{-3}$ & $-1.264 \times 10^{-3}$ \\
$\mathrm{CH}_{2} \mathrm{O}$ & $2.631 \times 10^{-3}$ & -- \\
$\mathrm{CO}_{2}$ (gas) & -- & $2.631 \times 10^{-3}$ \\
$\mathrm{O}_{2}$ (gas) & $7.462 \times 10^{-3}$ & $4.832 \times 10^{-3}$ \\
Chalcedony & $7.140 \times 10^{-5}$ & $7.140 \times 10^{-5}$ \\
$\mathrm{~K}_{-}$feldpsar & $1.475 \times 10^{-4}$ & $1.475 \times 10^{-4}$ \\
Kaolinite & $-7.377 \times 10^{-5}$ & $-7.377 \times 10^{-5}$ \\
CaX2 & $-4.674 \times 10^{-4}$ & $-4.674 \times 10^{-4}$ \\
NaX & $9.349 \times 10^{-4}$ & $9.349 \times 10^{-4}$ \\
Halite & $1.910 \times 10^{-4}$ & $1.910 \times 10^{-4}$ \\
\hline & & \\
\hline
\end{tabular}


